\title{
Legacy Data for a Northern Prairie Grassland-Woodworth Study Area, North Dakota, 1963-89
}
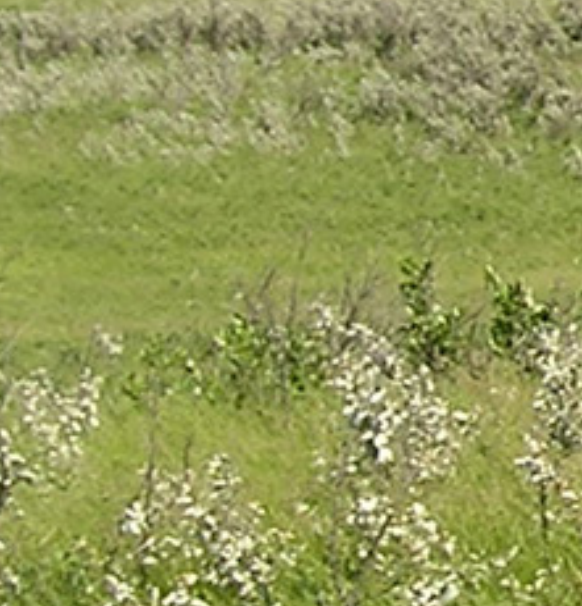

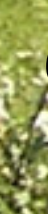
$3 \times 2$

pen-File Report 2014-1188
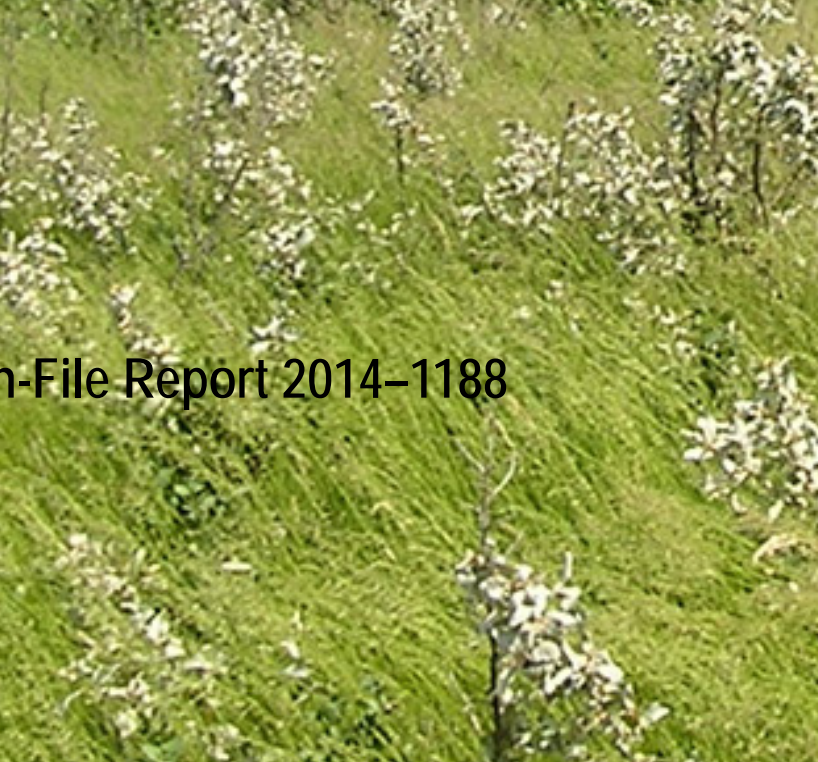

t.

(2)

U.: U

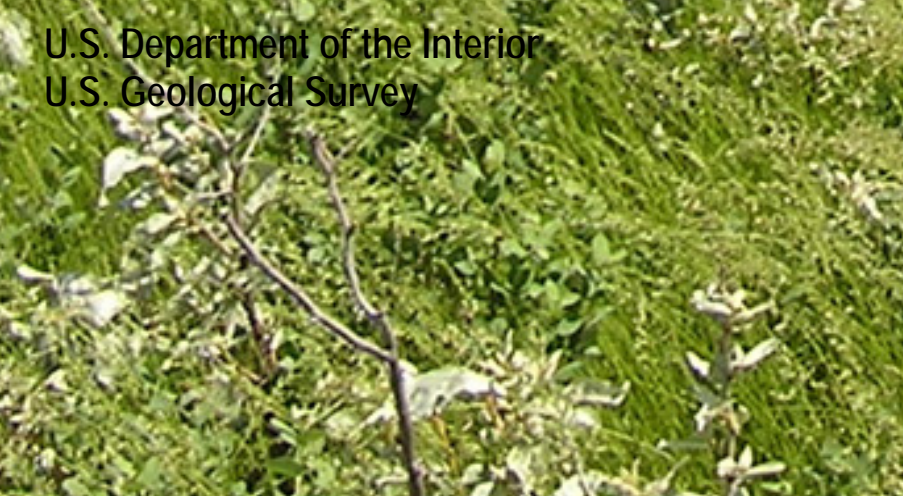
$4 \times-5)(7 x-1$

anthos 


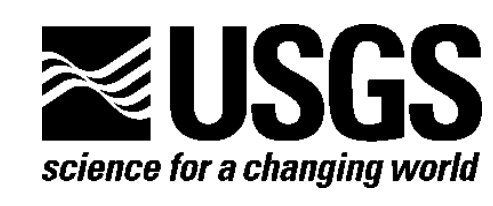

\section{Legacy Data for a Northern Prairie Grassland-Woodworth Study Area, North Dakota, 1963-89}

By Shelby H. Williams and Jane E. Austin

Open-File Report 2014-1188

U.S. Department of the Interior

U.S. Geological Survey 


\section{U.S. Department of the Interior SALLY JEWELL, Secretary}

\section{U.S. Geological Survey \\ Suzette M. Kimball, Acting Director}

U.S. Geological Survey, Reston, Virginia: 2014

For more information on the USGS-the Federal source for science about the Earth, its natural and living resources, natural hazards, and the environment-visit http://www.usgs.gov or call 1-888-ASK-USGS

For an overview of USGS information products, including maps, imagery, and publications, visit $h$ ttp://www.usgs.gov/pubprod

To order this and other USGS information products, visit http://store.usgs.gov

Suggested citation:

Williams, S.H., and Austin, J.E., 2014, Legacy data for a northern prairie grassland-Woodworth Study Area, North Dakota, 1963-89: U.S. Geological Survey Open-File Report 2014-1188, 85 p., http://dx.doi.org/10.3133/0fr20141188.

ISSN 2331-1258 (online)

Any use of trade, firm, or product names is for descriptive purposes only and does not imply endorsement by the U.S. Government.

Although this information product, for the most part, is in the public domain, it also may contain copyrighted materials as noted in the text. Permission to reproduce copyrighted items must be secured from the copyright owner. 


\section{Contents}

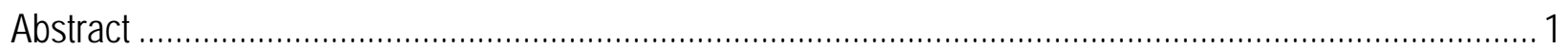

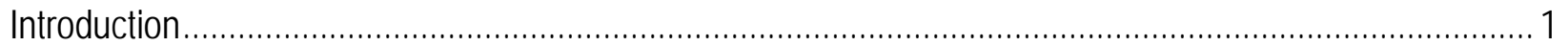

Administrative and Research History ....................................................................................

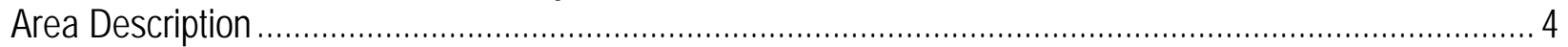

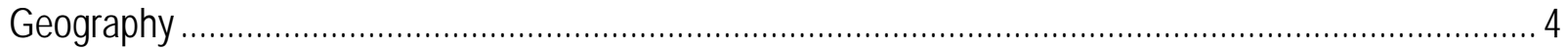

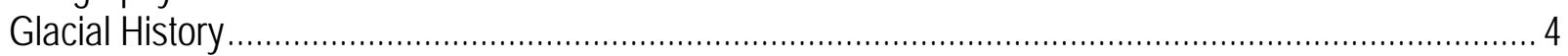

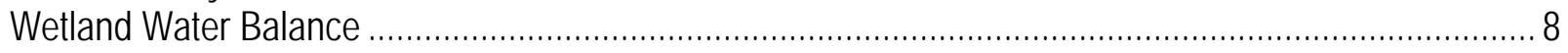

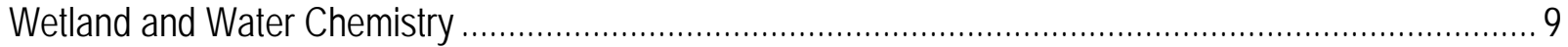

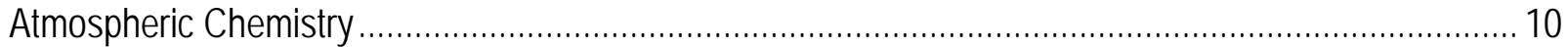

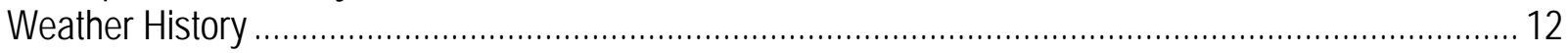

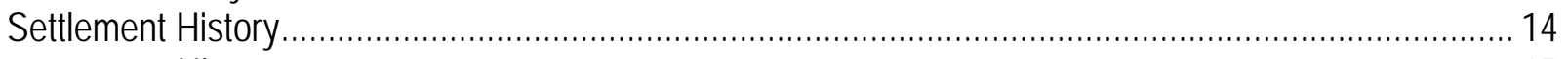

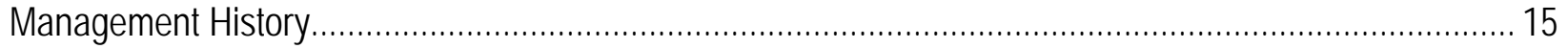

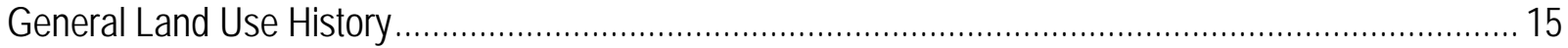

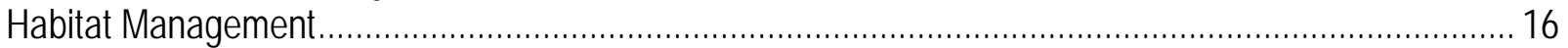

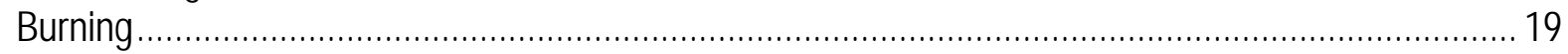

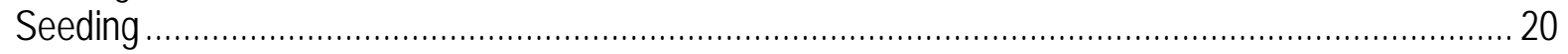

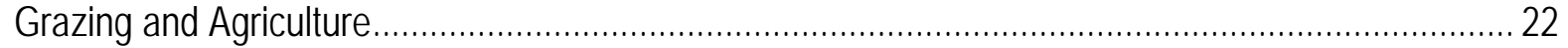

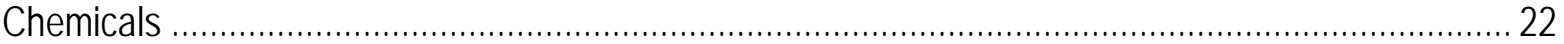

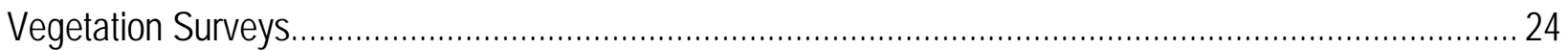

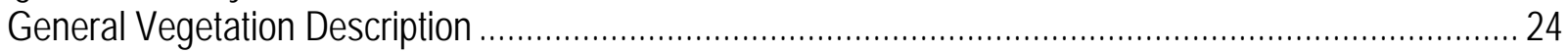

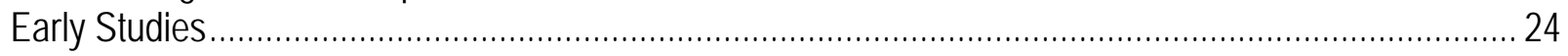

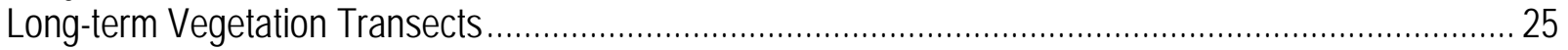

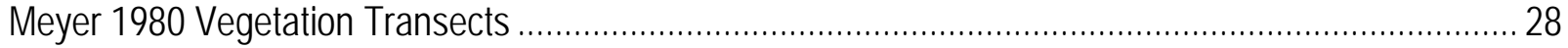

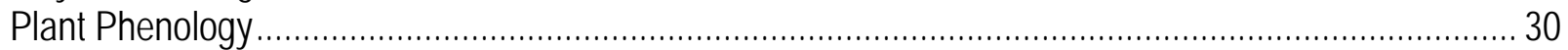

Vegetative Structure …….................................................................................................... 31

Wetlands and Wetland Vegetation................................................................................................ 33

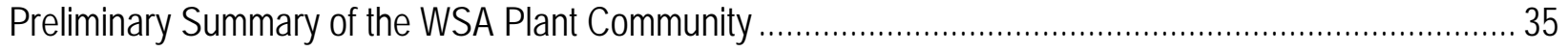

The WSA Plant Community …………………………

Floristic Quality Assessment ................................................................................................... 36

Additional Data Resources …........................................................................................... 38

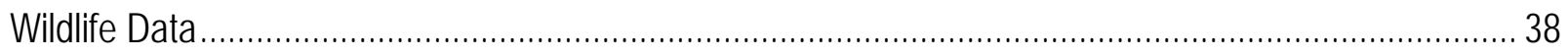

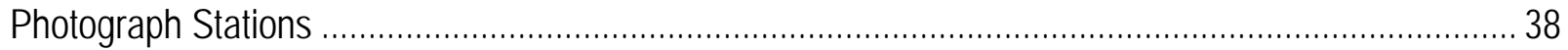

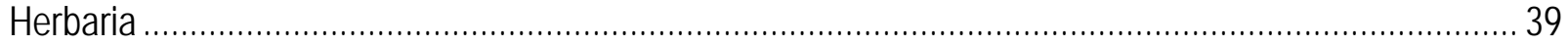

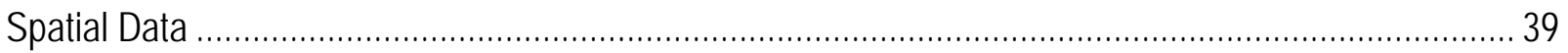

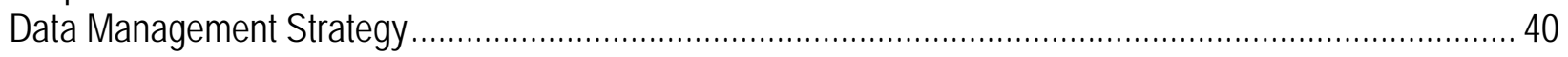

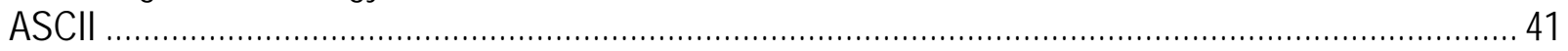

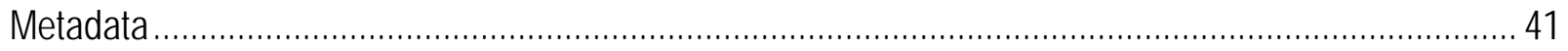

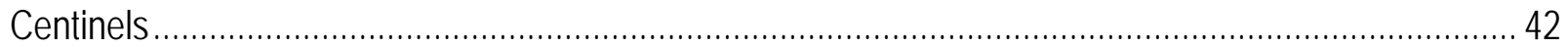

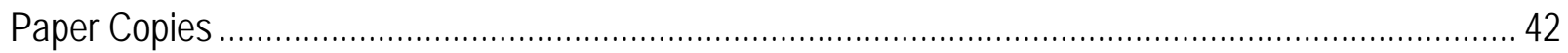

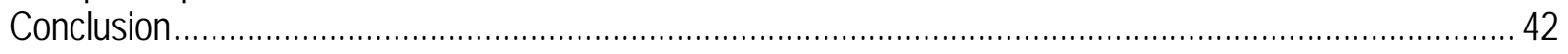

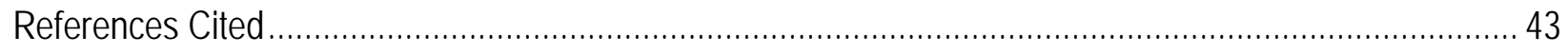

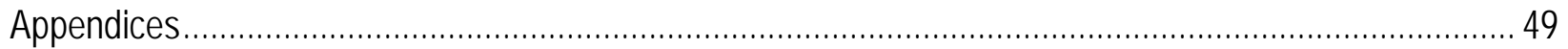


Appendix 1. Unpublished reports relating to the Woodworth Study Area (WSA) archived at Northern Prairie Wildlife Research Center ............................................................................................ 50 Appendix 2. Published and unpublished reports that use vegetation or weather data from the Woodworth

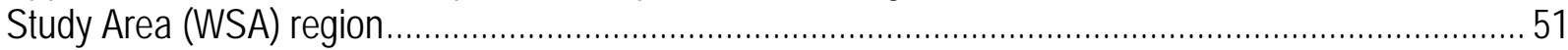
Appendix 3. Woodworth Study Area (WSA) tract locations and ownership........................................52 Appendix 4. Soil classifications at the Woodworth Study Area (WSA) using the Soil Survey Geographic Database (SSURGO). 54 Appendix 5. Original survey map of townships encompassing the Woodworth Study Area (WSA) from 1875

Appendix 6. Locations of man-made structures at the Woodworth Study Area (WSA) ..........................56 Appendix 7. Location of North Dakota cities and survey sites mentioned in the text..............................5 57 Appendix 8. Geographic Information System (GIS) layers of the Woodworth Study Area (WSA) available

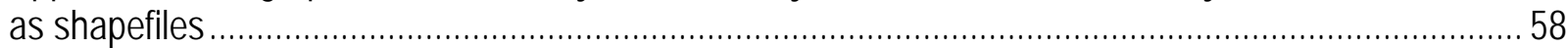
Appendix 9. Fertilizer treatments and locations at the Woodworth Study Area (WSA), 1966-75.............60 Appendix 10. Master list of vegetation found at the Woodworth Study Area (WSA) during 1966-89....... 62 Appendix 11. Plants collected at the Woodworth Study Area (WSA) and stored in the Northern Prairie Wildlife Research Center herbarium ........................................................................................ 74 Appendix 12. Aerial imagery available for the Woodworth Study Area (WSA) and surrounding area for $1957-97$

Appendix 13. Example of metadata used to document and preserve Woodworth Study Area (WSA) datasets

\section{Figures}

Figure 1. The Woodworth Study Area (WSA; 4708'N, 99014'W) lies within the Central Grasslands biome and Prairie Pothole Region (PPR) of eastern North Dakota and along the eastern edge of the Missouri Coteau physiographic region......................................................... 2

Figure 2. The terrain and elevation above sea level (meters [m]) of the Woodworth Study Area (WSA) based on light detection and ranging (lidar) data. ............................................................. 5

Figure 3. Spatial relation of underlying glacial features to test wells in and around the Woodworth Study Area (WSA). ............................................................................................

Figure 4. Soils of the Woodworth Study Area (WSA) ………....................................................

Figure 5. Changing water conditions in wetlands in the Woodworth Study Area during 1963............... 8

Figure 6. Monthly average concentrations of particulate pollutants at the Woodworth Study Area (WSA), Dunn Center, Park South, and Park North, North Dakota, in 1982......................... 12

Figure 7. Precipitation, temperature, and the Palmer Drought Severity Indices (PDSI) for the Woodworth Study Area (WSA) ................................................................................. 13

Figure 8. New broken ground and total area in cultivation of 24 quarter sections (1,550 hectares) around and including the Woodworth Study Area (WSA), 1903-55................................. 15

Figure 9. Numbered study units and fields at the Woodworth Study Area (WSA)............................ 17

Figure 10. Land use at the time of federal acquisition or agreement to use on the Woodworth Study Area (WSA), by study unit................................................................................. 17

Figure 11. Land uses and treatments for all fields on the Woodworth Study Area (WSA) during 1964-

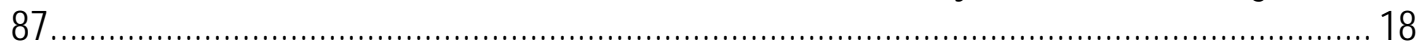

Figure 12. Total number and hectares of prescribed burns per month at the Woodworth Study Area (WSA) during 1965-84. 
Figure 13. Location of chemical treatments for control of undesirable species and fertilization on the Woodworth Study Area (WSA).

Figure 14. Land uses of the Woodworth Study Area (WSA) under federal management in $1964 \ldots \ldots \ldots . .25$

Figure 15. Locations of long-term vegetation transects (1966-89) and early vegetation transects (1963).26

Figure 16. Relative abundance of plant species surveyed in native fields at the Woodworth Study Area (WSA) in 1963, by their location in brush, upland, slope, or lowland areas. ........................ 26

Figure 17. Cumulative number of species recorded and number of long-term transects surveyed on the Woodworth Study Area (WSA) during 1966-89........................................................ 27

Figure 18. Survey dates for long-term transects at the Woodworth Study Area (WSA) during 1966-89.28

Figure 19. Approximate locations for the known vegetation transects surveyed in 1980 by Meyer (1985).29

Figure 20. First thorough vegetation map at the Woodworth Study Area (WSA) .............................. 29

Figure 21. Detailed plant community maps of 3 study units of the Woodworth Study Area (WSA) from

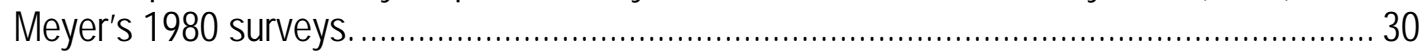

Figure 22. Transect locations for visual obstruction readings at the Woodworth Study Area (WSA)

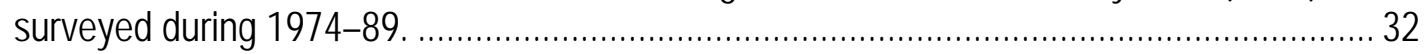

Figure 23. Measurement methods for vegetation density (visual obstruction reading [VOR]) and vegetation height using a Robel pole at the Woodworth Study Area (WSA)........................ 32

Figure 24. Wetland water regimes as identified by the National Wetland Inventory (NWI) at the Woodworth Study Area (WSA).

Figure 25. Summaries of plant types recorded on the Woodworth Study Area (WSA) during 1963-89. 36

Figure 26. The frequencies of coefficients of conservatism (C) scores for all taxa recorded at the Woodworth Study Area (WSA) during 1966-89.

Figure 27. Boxplots of the coefficients of conservatism $(C)$ of plants recorded on long-term transects on idle and treated fields during 1966-89. 37

Figure 28. Proportion of native plant species recorded each year (1966-89) by coefficients of conservatism (C) on long-term transects at the Woodworth Study Area (WSA).

Figure 29. Example of photographs taken at a photograph station (Station 8 in study unit 16) at the Woodworth Study Area (WSA) over multiple years. 39

Figure 30. Composite aerial photograph of the Woodworth Study Area (WSA) taken from 9,000 feet above the surface in May, 1963.

\section{Tables}

Table 1. Wells, springs, and test holes in and near the Woodworth Study Area (WSA) as of 1963..... 6 Table 2. Chemical analyses of water samples collected from Well C, Wetland 2, and Wetland 3 in 1960, 1963, and 1972 at the Woodworth Study Area (WSA)........................................ 10

Table 3. Concentration of ions from a rainfall sample at the Woodworth Study Area (WSA) from May to October 1982.

Table 4. Working definitions of actions applied to land at the Woodworth Study Area (WSA).......... 19

Table 5. $\quad$ Seeding mixtures used on a sample of fields at the Woodworth Study Area (WSA)............. 21 Table 6. Wetland types within the federal boundaries of the Woodworth Study Area, according to National Wetland Inventory classification (NWI). 


\section{Conversion Factors}

\begin{tabular}{lcl}
\multicolumn{1}{c}{ SI to Inch/Pound } & \multicolumn{1}{c}{ By } & \\
\hline & Length & \\
\hline centimeter $(\mathrm{cm})$ & 0.3937 & inch (in.) \\
meter $(\mathrm{m})$ & 3.281 & foot (ft) \\
decimeter & 0.3281 & foot (ft) \\
kilometer $(\mathrm{km})$ & 0.6214 & mile (mi) \\
\hline & Area & \\
\hline hectare $($ ha) & 2.471 & acre (ac) \\
square kilometer $\left(\mathrm{km}^{2}\right)$ & 247.1 & acre (ac) \\
square meter $\left(\mathrm{m}^{2}\right)$ & 10.76 & square foot $\left(\mathrm{ft}^{2}\right)$ \\
hectare (ha) & 0.003861 & square mile (mi $\left.{ }^{2}\right)$ \\
square kilometer $\left(\mathrm{km}^{2}\right)$ & 0.3861 & square mile $\left(\mathrm{mi}^{2}\right)$ \\
\hline & Density & \\
\hline kilograms per hectare $(\mathrm{kg} / \mathrm{ha})$ & 0.8922 & pounds per acre (lb/ac) \\
\hline
\end{tabular}

Temperature in degrees Fahrenheit $\left({ }^{\circ} \mathrm{F}\right)$ may be converted to degrees Celsius $\left({ }^{\circ} \mathrm{C}\right)$ as follows:

${ }^{\circ} \mathrm{C}=\left({ }^{\circ} \mathrm{F}-32\right) / 1.8$

Temperature in degrees Celsius $\left({ }^{\circ} \mathrm{C}\right)$ may be converted to degrees Fahrenheit $\left({ }^{\circ} \mathrm{F}\right)$ as follows:

${ }^{\circ} \mathrm{F}=\left({ }^{\circ} \mathrm{C} \times 1.8\right)+32$

Vertical coordinate information is referenced to the North American Vertical Datum of 1988 (NAVD 88).

Horizontal coordinate information is referenced to the North American Datum of 1983 (NAD 83).

Altitude, as used in this report, refers to distance above the vertical datum. 


\section{Abbreviations, Acronyms, and Chemical Symbols}

\begin{tabular}{|c|c|}
\hline $\mathrm{Al}_{3}^{+}$ & Aluminum \\
\hline ASCII & American Standard Code for Information Interchange \\
\hline C & Coefficient of conservatism \\
\hline $\mathrm{Ca}_{2}{ }^{+}$ & Calcium \\
\hline $\mathrm{Cl}^{-}$ & Chloride \\
\hline CLSA & Cottonwood Lake Study Area \\
\hline CLWMD & Chase Lake Wetland Management District \\
\hline $\mathrm{Fe}_{3}{ }^{+}$ & Ferrous iron \\
\hline $\mathbf{F}^{-}$ & Fluoride \\
\hline FQI & Floristic Quality Index \\
\hline FWS & U.S. Fish and Wildlife Service \\
\hline GIS & Geographic Information system \\
\hline $\mathrm{H}^{+}$ & Hydrogen \\
\hline $\mathrm{HCO}_{3}^{-}$ & Bicarbonate \\
\hline $\mathrm{K}^{+}$ & Potassium \\
\hline $\mathrm{Mg}_{2}^{+}$ & Magnesium \\
\hline $\mathrm{Mn}_{2}{ }^{+}$ & Manganese \\
\hline $\mathrm{Na}^{+}$ & Sodium \\
\hline NEON & National Ecological Observatory Network \\
\hline $\mathrm{NH}_{4}^{+}$ & Ammonium \\
\hline $\mathrm{NO}_{3}^{-}$ & Nitrate \\
\hline NPWRC & Northern Prairie Wildlife Research Center \\
\hline NWI & National Wetland Inventory \\
\hline PDSI & Palmer Drought Severity Index \\
\hline $\mathrm{PO}_{4}^{-}$ & Phosphate \\
\hline PPR & Prairie Pothole Region \\
\hline SSURGO & U.S. Department of Agriculture Soil Survey Geographic Database \\
\hline $\mathrm{SO}_{4}^{-}$ & Sulfate \\
\hline USGS & U.S. Geological Survey \\
\hline VOR & Visual obstruction method \\
\hline WSA & Woodworth Study Area \\
\hline $\mathrm{Zn}_{2}^{+}$ & Zinc \\
\hline
\end{tabular}




\section{Acknowledgments}

This project was funded by the U.S. Fish and Wildlife Service (FWS), Chase Lake Wetland Management District (CLWMD) Inventory and Monitoring initiative, and the U.S. Geological Survey (USGS) at North Prairie Wildlife Research Center (NPWRC). The authors would like to thank the following people for their contributions to this document:

Neil Shook, Project Officer, U.S. Fish and Wildlife Service, Chase Lake Wetland Management District, and Cami Dixon, Inventory and Monitoring Biologist, U.S. Fish and Wildlife Service, for their helpful discussions, project direction, and access to data relating to the Woodworth Study Area.

Staff of Northern Prairie Wildlife Research Center (NPWRC) David Cunningham, Betty Euliss, and Larry Strong for software and technical help, and David Mushet and Robert Woodward for assistance in finding and interpreting historical data.

NPWRC emeritus staff Ken Higgins and David Trauger for consulting on historical data sets and area history.

Donald Rosenberry, Hydrologist, U.S. Geological Survey, and Stan Kohn, Biologist, North Dakota Game and Fish Department, for assistance with finding historical data.

Brian Wangler, Wildlife Biologist, U.S. Fish and Wildlife Service, for loan of aerial imagery.

Clarence Lehman, Professor, University of Minnesota, for data management assistance.

Staff at Alfred Dickey Public Library in Jamestown, North Dakota, and State Historical Society of North Dakota in Bismarck, North Dakota, for help with history of the Woodworth Study Area.

Ken Higgins, David Trauger, and Ryan Limb, North Dakota State Univesity, provided valuable comments on early versions of this report. 


\title{
Legacy Data for a Northern Prairie Grassland: Woodworth Study Area, North Dakota, 1963-89
}

By Shelby H. Williams and Jane E. Austin

\begin{abstract}
Ecological data commonly become more valuable through time. Such legacy data provide baseline records of past biological, physical, and social information that provide historical perspective and are necessary for assessment of stasis or change. Legacy data collected at the Woodworth Study Area (WSA), a contiguous block of grasslands, croplands, and wetlands covering more than 1,000 hectares of the Prairie Pothole Region of North Dakota, are cataloged and summarized in this study. The WSA is one of the longest researched grassland sites in the Upper Midwest. It has an extensive history of settlement, land use, and management that provides a deeper context for future research. The WSA data include long-term vegetation transect records, land use history, habitat management records, geologic information, wetland hydrology and chemistry information, and spatial images. Substantial parts of these data have not been previously reported. The WSA is representative of many other lands purchased by the U.S. Fish and Wildlife Service in the Prairie Pothole Region from the 1930s to the 1970s; therefore, synthesized data from the WSA are broadly applicable to topics of concern in northern grasslands, such as increases in non-native plants, managing for biodiversity, and long-term effects of habitat management. New techniques are also described that were used to preserve these data for future analyses. The data preservation techniques are applicable to any project with data that should be preserved for 100 years or more.
\end{abstract}

\section{Introduction}

Many North American wetlands were rapidly lost during early half of the 1900s to the combined forces of the severe drought of the 1930s, increasing drainage activities, and mechanization of farming. By the 1950s, leading biologists recognized that migratory waterfowl and their wetland habitats were in "grave danger" (Gabrielson, 1958). One response by the U.S. Fish and Wildlife Service (FWS) was an intensive effort in the late 1950s and 1960s to acquire wetland habitat for migratory waterfowl. Much of that effort, fueled by federal Duck Stamp funds (Higgins, 1981), was focused on the Prairie Pothole Region (PPR; fig. 1) which is known for its abundant wetlands and waterfowl productivity (Mann, 1958; Batt and others, 1989).

Acquisition and protection of wetlands through a combination of fee title purchases and easements, however, were recognized as insufficient to sustain productivity of migratory waterfowl populations. By the 1950s, wildlife biologists and managers were beginning to understand the intricate relation between the welfare of wildlife populations, and the quantity and quality of habitat, but much remained unknown. Nelson and Lee (1966) noted that "[m]ore sophisticated and penetrating research is needed to build a solid foundation of facts to guide future management of the Continent's waterfowl resources.” Biologists also recognized as early 
as the 1930s that a large percentage of wildlife species were produced on private land (Leopold, 1933). Hence, scientific research was needed to help guide management of upland and wetland habitats for the benefit of waterfowl and other wildlife, yet be economically feasible and acceptable to land owners (Cottam, 1958). New habitat management techniques needed to be properly researched and tested before being made available to managers and landowners.

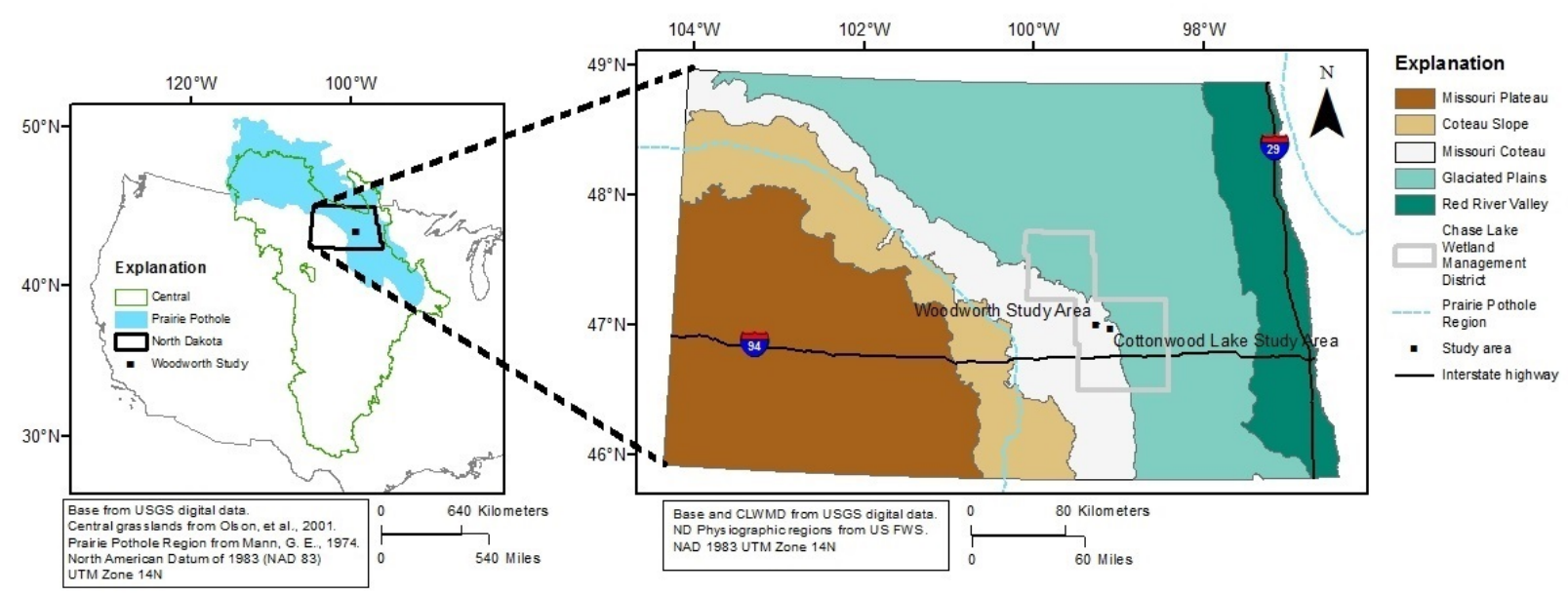

Figure 1. The Woodworth Study Area (WSA; 4708'N, 99014'W) lies within the Central Grasslands biome and Prairie Pothole Region (PPR) of eastern North Dakota and along the eastern edge of the Missouri Coteau physiographic region.

To address these pressing needs, FWS personnel sought a permanent study area that would provide opportunities for short-term and long-term research on priority issues confronting the management of migratory birds and their habitats in the PPR. Primary emphasis was on wetland and grassland ecology, waterfowl breeding ecology, and the effects of agricultural land use practices on waterfowl production. In the early 1960s, Dr. Ingalf G. Bue was given a special assignment by FWS to find an appropriate area to establish a field research station. The criteria were that the area (1) be representative of the PPR, (2) be on the Coteau du Missouri (or Missouri Coteau), (3) be a sizeable tract, (4) have a high density of wetlands, and a matrix of native grasslands and croplands, and (5) be within 80 kilometers $(\mathrm{km})$ of the new Northern Prairie Wildlife Research Center (NPWRC) in Jamestown, North Dakota (Nelson and Lee, 1966). Dr. Bue selected a 1,063-hecatare (ha) area near Woodworth, North Dakota (N. Dak.). The Woodworth Study Area (WSA) was purchased using federal Duck Stamp funds in 1963 and designated a waterfowl production area to help meet the research needs of the NPWRC. The initial intent of the WSA was to establish and maintain a long-term study area and collection of baseline data that would serve future studies. The primary mission of the WSA was to conduct research concerning the best land use and water management practices that would also keep with the mission of the FWS to maximize benefits to wildlife, with an emphasis on migratory birds.

The WSA stands as one of the longest researched grassland sites in the Upper Midwest (Johnson and others 1996). The WSA has an extensive history of settlement, land use, and management that provides a deeper context for investigations. It is representative of many other tracts purchased by the FWS in the PPR during the 1930s-1970s. In addition to research on 
wildlife responses to habitat management, the WSA hosted extensive research on the ecology of waterfowl, grassland birds, and predators (Higgins and others, 1992). Data include vegetation, birds, mammals, soils, lands use and treatments, and weather. More than 30 years of research at the WSA resulted in volumes of data, 66 peer-reviewed publications, 16 theses, and many other published and unpublished reports on management of wetlands and wildlife. Data collected at the WSA also contributed directly to several domestic and international environmental policies including U.S. farm bills and the North American Waterfowl Management Plan (Nelson, 1996).

However, a substantial part of the historical data collected at the WSA, particularly the vegetation data, has never been comprehensively assessed. Long-term records of vegetation composition, structure, and phenology remain largely digitized. Data from the early decades of habitat research were stored in paper files and as American Standard Code for Information Interchange (ASCII) datasets in NPWRC archives, and subject to limited or absent metadata, and often no comprehensive explanation. Extensive information about early land use by settlers, land management histories, and other aspects of the area existed in various unpublished reports (appendix 1) and memos.

This report provides a compilation and synthesis of the WSA's settlement and land management history, geography, abiotic features, vegetation data, and associated research conducted during 1963-89. The first section provides a general orientation to the geography, physical features, and settlement history of the WSA area. The second section describes the land use history and treatments applied under federal management. The third section presents a preliminary summary of the long-term vegetation data. Parts of the WSA vegetation data were published previously as supporting data in wildlife-related publications (appendix 2), but this is the first compilation and synthesis of the core vegetation datasets from the first 3 decades of WSA research. In the final section, the data management strategy used to ensure that these valuable data will be accessible to researchers for a century or more is described. This project meets the diverse requirements of the Chase Lake Wetland Management District (CLWMD), FWS, and NPWRC. It also serves as a foundation for analyzing the WSA legacy data and future data, most notably those from the National Ecology Observatory Network (NEON) Domain 9 core site, which was established at the WSA in 2013 and is expected to remain there until 2047 (NEON, Inc., 2011).

As climate and land use continue to change in the PPR, the historical WSA datasets offer context and a baseline for future work on grassland reserves. These datasets will contribute to CLWMD's planning process for their habitat management plan by forming a solid baseline of historic vegetation conditions. In addition, this information can be critical as biologists consider how abiotic factors and biotic factors have changed, and how the landscape can be better managed considering these changes.

\section{Administrative and Research History}

The WSA has been owned by the FWS since its purchase from private landowners (appendix 3) and was managed by NPWRC personnel until 1993. The WSA was managed by Leo M. Kirsch (1964-79), Kenneth F. Higgins (1979-85), and J. Michael Callow (1985-89). Occasionally, private lands adjacent to the WSA also were used with permission in research and monitoring, such as monitoring wetland conditions. Most of the research was conducted by scientists and staff affiliated with the NPWRC; in addition, some 300 visiting scientists from state and federal agencies, universities, and graduate students have conducted research there (Johnson and others, 1996). In 1990, the WSA became headquarters for the Chase Lake Project 
of the Prairie Pothole Joint Venture under the North American Waterfowl Management Plan. Thus the WSA has been a model of partnerships between government agencies, university researchers, and private ownership.

During 1989-93, the FWS contributed to management of the WSA with on-site biologists in conjunction with researchers from the NPWRC. In 1993, the FWS retained ownership of the WSA lands when the NPWRC was transferred from the FWS to the National Biological Survey and in 1997 to the U.S. Geological Survey. Operational management was shared between the NPWRC and FWS's newly established CLWMD through formal agreements. The NPWRC maintained active research on the WSA until 1996 but continues some long-term data collection.

\section{Area Description}

\section{Geography}

The WSA is in east-central North Dakota within the PPR and Central Grasslands biome of North America (fig. 1). It is about 5 km east of Woodworth, N. Dak., on the Missouri Coteau at latitude $47^{\circ} 8^{\prime} \mathrm{N}$ and longitude $99^{\circ} 14^{\prime} \mathrm{W}$ (fig. 1). The PPR is a formerly glaciated region defined by high densities of shallow wetlands (potholes) embedded in northern mixed-grass prairie. The Missouri Coteau is a prominent terminal glacial moraine, a narrow band of land that separates the more intensively cultivated landscape of the Glaciated Plains to the east from the Missouri Plateau to the west (fig. 1). Its irregular terrain supports hay fields, a variety of crops, native prairie, and range lands with livestock (fig. 2). The WSA consists of 1,063 hectares (ha) of land in federal management; an additional 168 ha of privately owned lands adjoining the WSA have been surveyed occasionally under agreements with their owners (appendix 3; Higgins and others, 1992).

\section{Glacial History}

The WSA is representative of how glaciation processes created the high densities of wetlands characteristic of the PPR. Almost one-fifth of the WSA is covered in wetlands formed by glacial retreat. The age of the glacial drift on the Missouri Coteau is estimated to be from 9,000 years (Tutill and others, 1964) to 13,000 years before present (Clayton, 1966; Higgins and others, 1992). The WSA is divided into 2 glacial landforms: hummocky stagnation moraine in the northwest and outwash in the southeast (fig. 3; Winters, 1963). The hummocky stagnation moraine in the northwest was created by glacial stagnation, where the Wisconsin glacier slowly disintegrated and melted in place over thousands of years. Glacial till that accumulated within the glacier eventually rested in a disorganized layer on the surface, forming hummocky stagnation moraine (Bluemle, 1987). The topography is an irregular distribution of mounds and depressions, and some of the rugged local relief exceeds 30 meters per square kilometer $\left(\mathrm{m} / \mathrm{km}^{2}\right)$ (Higgins and others, 1992). Till material is unsorted, so water moves through it more easily near the surface, affecting wetland hydrology (Sloan, 1972).

The southeast corner of the WSA is a glacial outwash (fig. 3), which contains deposits from streams of glacial melt water flowing on the glacier surface (Winters, 1963). Soil formed on outwash can be highly permeable, which results in fewer but more permanent potholes than in adjacent deposited till (Sloan, 1972). The outwash plain covering the southeast portion of the WSA was characterized as "ice-walled gravel train" by Winters (1963, p. 44). The swath of outwash is about $2.4 \mathrm{~km}$ wide (fig. 3) and was once bordered by ice walls on the north and south 


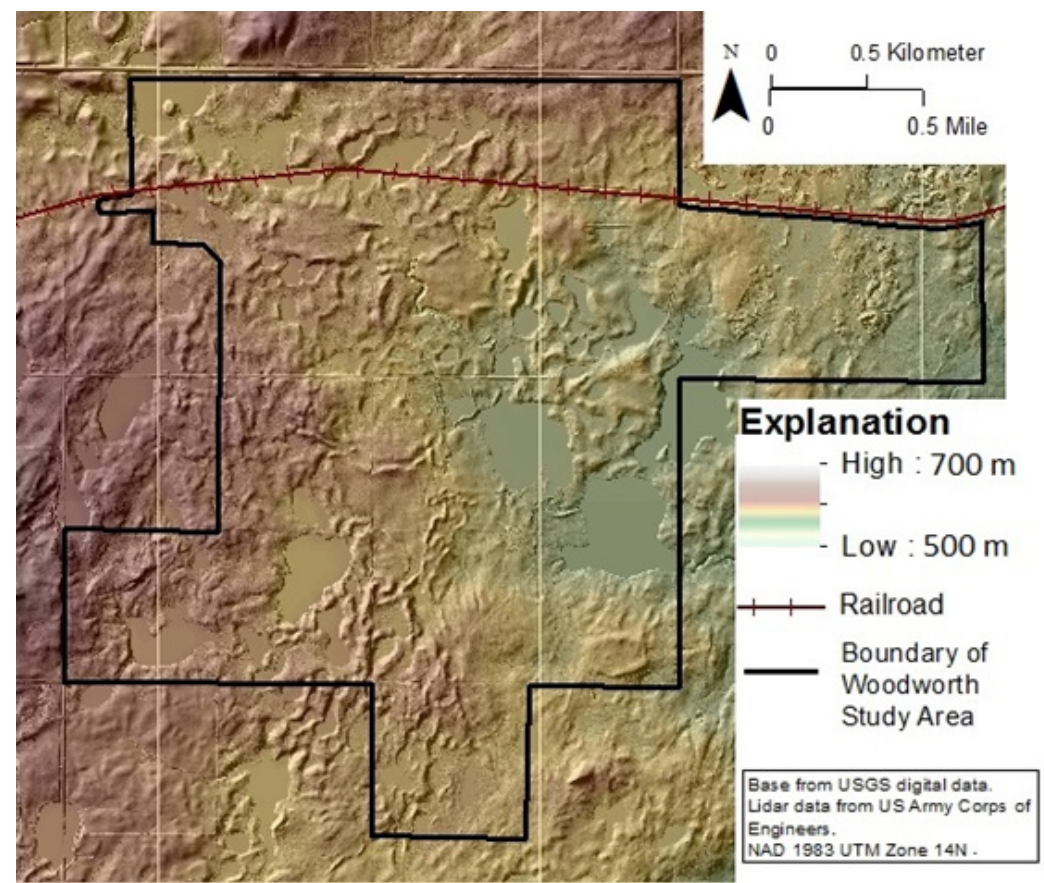

Figure 2. The terrain and elevation above sea level (meters [m]) of the Woodworth Study Area (WSA) based on light detection and ranging (lidar) data.

$A$

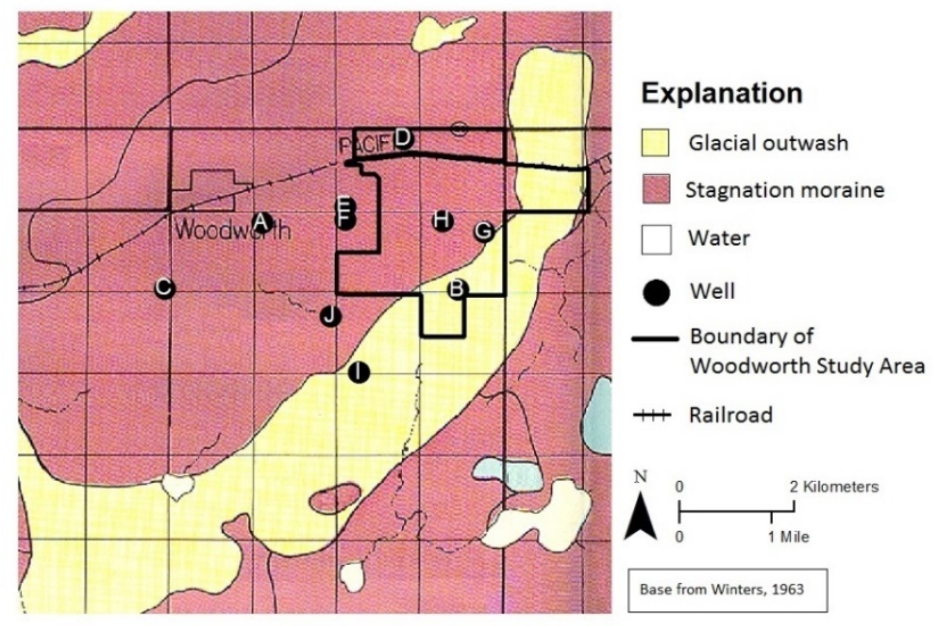

B

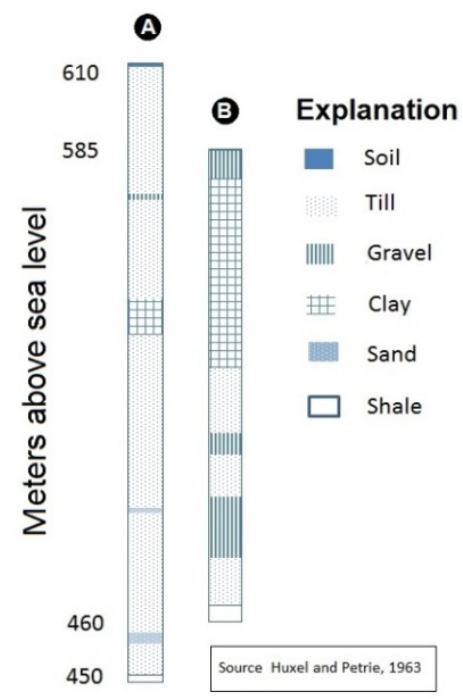

Figure 3. Spatial relation of underlying glacial features to test wells in and around the Woodworth Study Area (WSA). ). A, A band of glacial stagnation outwash runs through hummocky stagnation moraine in the southeast swath of the WSA. Test wells were located in both areas and were mapped to within 4 ha. $B$, Vertical profiles of substrate material in test wells $A$ and $B$. 
sides. This resulted in rugged terrain similar to hummocky stagnation moraine and is indistinguishable from stagnation based on topography alone (Winters, 1963). In the northeastern study units of the WSA, exposed gravel pits were developed commercially until 1953; coarse gravel deposits were at least 7.5 meters (m) deep (Winters, 1963). The commercial history, and plant and animal communities of this so-called Goldwin gravel pit were published by Higgins (1982). WSA staff also created a small gravel pit about $0.75 \mathrm{~km}$ east of headquarters on the outwash.

At least 10 wells, springs, and test holes near the WSA have been examined (table 1; fig. 3; Huxel and Petri, 1963). Data available for 2 wells illustrate the differences between profiles of glacial deposits of hummocky stagnation moraine and stagnation outwash. Test well 1815 (A) was dug about $2.5 \mathrm{~km}$ west of the WSA on hummocky stagnation moraine; below a thick layer of soil (0.9 m) was almost $33 \mathrm{~m}$ of glacial till (fig. 3). Test well 1814 (B) was dug $4 \mathrm{~km}$ east of Test well 1815 (A) on the stagnation outwash (fig. 3). Test 1814 (B) revealed mainly gravel and clay below $0.61 \mathrm{~m}$ of soil; $7.3 \mathrm{~m}$ of gravel was followed by $49.1 \mathrm{~m}$ of clay (fig. 3; Huxel and Petri, 1963).

Table 1. Wells, springs, and test holes in and near the Woodworth Study Area (WSA) as of 1963.

[Ownership indicates whether the well was on federally owned or private land. No data is indicated by nd. Letters were assigned for IDs in the present report and correspond to figure 3. Year established is the year that the well, test hole, or spring was dug, if known. Depth is recorded as meters $(\mathrm{m})$, diameter as centimeters $(\mathrm{cm})$, and specific conductance as micromhos per centimeter $(\mu \mathrm{mho} / \mathrm{cm})$. Material indicates substrate type. Site $\mathrm{H}$ had no water depth recorded but water flowed (a fen with moving groundwater). Data from Huxel and Petri, 1963.]

\begin{tabular}{cccccccc}
\hline ID & Ownership & $\begin{array}{c}\text { Year } \\
\text { established }\end{array}$ & $\begin{array}{c}\text { Depth } \\
(\mathbf{m})\end{array}$ & $\begin{array}{c}\text { Diameter } \\
(\mathbf{c m})\end{array}$ & Material & $\begin{array}{c}\text { Water } \\
\text { depth } \\
(\mathbf{m})\end{array}$ & $\begin{array}{c}\text { Specific conductance } \\
(\boldsymbol{\mu} \text { mho/cm })\end{array}$ \\
\hline A & Private & 1960 & 160 & 12.7 & nd & nd & nd \\
B & Federal & 1960 & 121.6 & 12.7 & nd & nd & nd \\
C & Private & 1960 & 135.6 & 5.1 & fine sand & 68.6 & nd \\
D & Federal & nd & 64.6 & 10.2 & sand & 9.1 & 1,302 \\
E & Private & nd & 12.2 & 61.0 & sand & nd & nd \\
F & Private & nd & 6.1 & 61.0 & sand & nd & nd \\
G & Federal & nd & 12.2 & 61.0 & gravel & 8.5 & nd \\
H & Federal & nd & 2.6 & 121.9 & gravel & Flow & 670 \\
I & Private & 1949 & 15.2 & 61.0 & sand & 12.2 & nd \\
J & Private & 1956 & 62.5 & 5.1 & sand & 36.6 & nd \\
\hline
\end{tabular}

Glacial formations are the substrata or parent materials from which agricultural soils were formed. According to the Soil Survey Geographic Database (SSURGO) classifications (U.S. Department of Agriculture, 2009), there are eight soil series throughout the WSA (4B); the most common is the Buse series, followed by Barnes (fig. 4B). Bayha's (written commun., 1963) soil survey contained more categories of soil (fig. 4A) but agrees with 2009 SSURGO data that the primary soil type (as defined in 1963) was Buse-Barnes (fig. 4B; Omodt and others, 1968; Patterson and others, 1968). Soils also were classified by drainage, runoff, and farmland types (appendix 4). Vegetation studies at the WSA usually accounted for varieties and differences in 
soil types when choosing locations for transect surveys and controls. For an in-depth discussion of soil types at the WSA and the surrounding area, see the Stutsman County Soil Report (Abel and others, 1995).
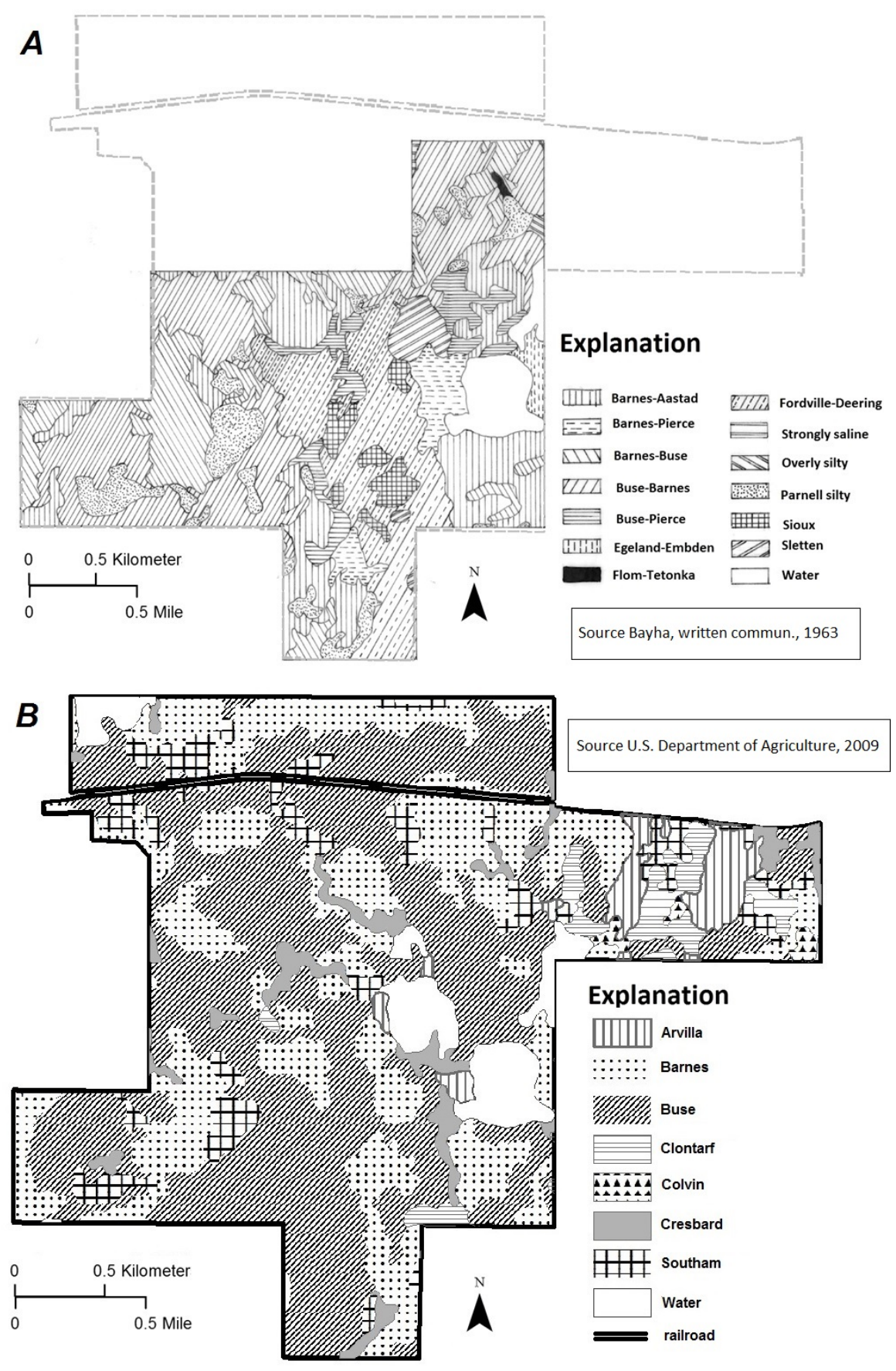

Figure 4. Soils of the Woodworth Study Area (WSA). A, Bayha's initial survey in 1963. B, Publicly available Soil Survey Geographic Database (SSURGO) database. 


\section{Wetland Water Balance}

There are no primary stream drainages from the WSA, and most surface runoff on the study site accumulates in wetland depressions (Higgins and others, 1992). The amount of water in a wetland basin is constrained by 2 dynamic factors: groundwater hydrology and atmospheric hydrology (Euliss and others, 2004). Research at the nearby Cottonwood Lake Study Area (CLSA) indicates wetland dynamics were mainly driven by evaporative losses and precipitation inputs (Winter and Rosenberry, 1995). Minor additions to water levels were supplied from overland runoff or groundwater seepage, and direction and volume of seepage between a wetland basin and groundwater can vary on a seasonal or interannual basis (Euliss and others, 2004). Wetlands may also lose water through transpiration via wetland vegetation. Transpiration varied with the amount, height, and moisture content of wetland vegetation, and was about 15 percent higher for vegetated basins than unvegetated basins (Eisenlohr, 1972).

The seasonal and interannual climate cycles that drive wetland water levels are integral to wetland processes and biotic communities (Euliss and others, 2004). Maps created by Bayha (written commun., 1963) illustrated seasonal changes in wetland water volume at the WSA during the dry year of 1963 (fig. 5). Water surfaces shrank from May to November, and demonstrate differences in wetland permanence between the east and west halves of the WSA (fig. 5). The percentage of basins at the WSA containing water at various times throughout the year was first reported in Bayha (written commun., 1963) and later by Higgins and others (1992).
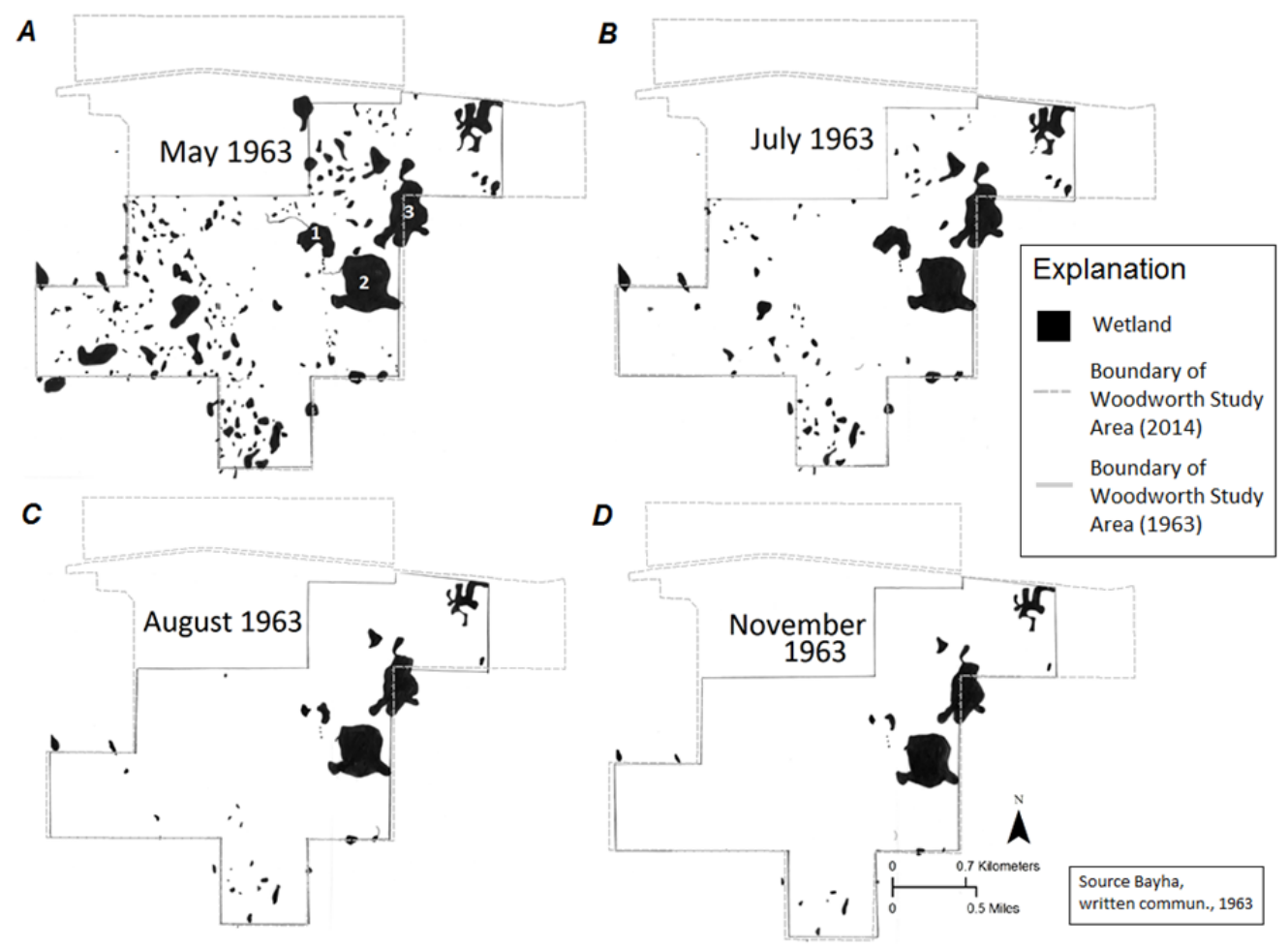

Figure 5. Changing water conditions in wetlands in the Woodworth Study Area (WSA) during 1963. A, May, 1963. Wetlands 1, 2, and 3 are also known as Clark Lake, Fish Lake, and Big Lake, respectively; in Northern Prairie Wildlife Research Center archives they are labeled as 11-5, 11-17, and 10-2, respectively. B, July, 1963. C, August, 1963. D, November, 1963. 
Changes in individual wetland levels were also measured with gages in some years. Eisenlohr (1972, p. A30) demonstrated the weekly fluctuations in 3 large wetlands at the WSA from 1963 to 1965. Clark Lake (labeled wetland 1 in fig. 5) is spring fed and naturally outflows into Fish Lake (wetland 2) and Big Lake (wetland 3; fig. 5). The outlet of Big Lake was sealed off, and an earthen dam containing a 76.2-cm culvert and a gate valve was constructed in April 1965 (Eisenlohr 1972). This retained all runoff reaching the basin, creating a more permanent wetland. Water heights for an additional 15 wetlands were recorded with gages during 1963-64. In a different dataset from 1964 to 1989, WSA staff recorded water amounts of 651 individual wetlands in and near the WSA using a subjective scale of 1 through 8 . There was an average of almost 100 measurements (range 1-129) for each wetland. Both of these datasets are available at the NPWRC. Historical records also illustrate wetland dynamics. Bayha's (written commun., 1964a) social history and early maps recorded that the 3 largest wetlands at the WSA were named Clark Lake (labeled wetland 11-5), Fish or Rosella Lake (wetland 11-17), and Big or Dittbenner Lake (wetland 10-2); these are labeled 1, 2, and 3, respectively on figure 5. Bayha (written commun., 1964a) reported that all of Big Lake and part of Fish Lake were dry in 1936 during a period of severe drought, and residents were able to harvest 20 tons of hay from the basins. Nearly a century earlier, original township surveys from 1875 (appendix 5) documented these primary wetlands. Of the 3 large wetlands in the WSA, only Big Lake appeared in the original township surveys, likely because the others are not located on section lines.

Several wetlands were modified after federal acquisition with small earthwork dams. Dams and other man-made structures associated with wetlands at the WSA are mapped in appendix 6.

\section{Wetland and Water Chemistry}

Many surface waters in wetlands interact with groundwater in complex ways (Winter and Rosenberry, 1995). Wetlands tend to be connected with groundwater and exchange water and dissolved solids. Thus, dissolved solids leave a wetland through seepage outflow to groundwater or, less commonly, when a wetland overflows. Therefore, the brackishness of wetlands is determined by the rate of seepage outflow or overflow in relation to the amount of water and input of solids (Eisenlohr, 1972). Wetlands on outwash regions, such as the southeastern onethird of the WSA, tend to have greater seepage from groundwater into basins than from wetlands on till. The trapped salts create brackish or saline water in these outwash wetlands (Stewart and Kantrud, 1972).

Several studies examined water chemistry in wetlands and in groundwater at the WSA since the early 1960s. Dissolved solids in spring-fed wetland 1 (labeled in figure 5) in 1963 ranged from 740 to 800 parts per million (Eisenlohr, 1972). Wetlands 2 and 3 were sampled in 1963 and 1972, and groundwater in a private well near the WSA was analyzed in 1960 (table 2). Water chemistries of Wetlands 2 and 3 were largely consistent with each other and those of wetland 2 was consistent over time. The wetlands sampled had higher concentrations of the magnesium (Mg) and potassium (K) than the well sample, and lower concentrations of chloride $\left(\mathrm{Cl}^{-}\right)$, sodium $(\mathrm{Na})$, and bicarbonate $\left(\mathrm{HCO}_{3}{ }^{-}\right)$. Sulfate $\left(\mathrm{SO}_{4}{ }^{-}\right)$in Wetland 2 samples from 1963 were higher than in the 1972 samples. The specific conductance levels place the wetlands in the slightly to moderately brackish category of Stewart and Kantrud (1972). The groundwater sample from the private well is closer to moderately brackish. 
Table 2. Chemical analyses of water samples collected from Well C, Wetland 2, and Wetland 3 in 1960, 1963, and 1972 at the Woodworth Study Area (WSA).

[Location of Well C is shown in figure 3; locations of Wetlands 2 and 3 are shown in figure 5 . Wetland 2 was sampled in 1963 and 1972; it is also known as 11-17 by WSA naming convention or informally as Fish Lake. Wetland 3 is also known as 10-2 by WSA naming convention or informally as Dittbenner or Big Lake. Calculated dissolved solids were measured as residue at $180^{\circ} \mathrm{C}$ in parts per million (ppm). Specific conductance is in microsiemens per centimeter $(\mu \mathrm{S} / \mathrm{cm})$ at $25^{\circ} \mathrm{C}$. Element and compound measurements are milligrams per liter (mg/L). Well C was privately owned, $136 \mathrm{~m}$ deep, and had a water temperature of $43^{\circ} \mathrm{F}$. No data is indicated by nd.]

\begin{tabular}{|c|c|c|c|c|}
\hline Attribute & $\begin{array}{c}\text { Well C } \\
1960\end{array}$ & $\begin{array}{c}\text { Wetland } 2 \\
1963\end{array}$ & $\begin{array}{c}\text { Wetland } 2 \\
1972\end{array}$ & $\begin{array}{c}\text { Wetland } 3 \\
1972\end{array}$ \\
\hline Data source & $\begin{array}{l}\text { Huxel and } \\
\text { Petri, } 1963\end{array}$ & $\begin{array}{c}\text { Eisenlohr, } \\
1972\end{array}$ & $\begin{array}{l}\text { Swanson and } \\
\text { others, } 1988\end{array}$ & $\begin{array}{l}\text { Swanson and } \\
\text { others, } 1988\end{array}$ \\
\hline Date sampled & May 9, 1960 & Oct. 29, 1963 & July 1972 & July 1972 \\
\hline Calculated dissolved solids (ppm) & 1,340 & 796 & nd & $\mathrm{Nd}$ \\
\hline Specific conductance $(\mu \mathrm{S} / \mathrm{cm})$ & 2,060 & 1,070 & 1,160 & 1,300 \\
\hline $\mathrm{pH}$ & 7.4 & 9.1 & 9.1 & 9.2 \\
\hline Bicarbonate $\left(\mathrm{HCO}_{3}^{-}\right)(\mathrm{mg} / \mathrm{L})$ & 677 & 21 & nd & nd \\
\hline Calcium (Ca) (mg/L) & nd & 17 & 13 & 15 \\
\hline Chloride $\left(\mathrm{Cl}^{-}\right)(\mathrm{mg} / \mathrm{L})$ & 163 & 20 & 20 & 20 \\
\hline Magnesium (Mg) (mg/L) & 25 & 97 & 108 & 130 \\
\hline Potassium (K) (mg/L) & 12 & 29 & 24 & 28 \\
\hline Sodium (Na) (mg/L) & 357 & 69 & 60 & 89 \\
\hline Sulfate $\left(\mathrm{SO}_{4}^{-}\right)(\mathrm{mg} / \mathrm{L})$ & 340 & 326 & 190 & 140 \\
\hline
\end{tabular}

\section{Atmospheric Chemistry}

Surrounding land use left a fingerprint in precipitation chemistry at the WSA. Results from a North Dakota Department of Health study (Angelo and Anderson, 1983) indicated significantly greater concentration of ammonium $\left(\mathrm{NH}_{4}{ }^{+}\right.$) at the WSA (table 3) than at Dunn Center, N. Dak., or Canfield Lake, N. Dak. Dunn Center is $250 \mathrm{~km}$ west of the WSA (appendix 7) and was in the center of coal, oil, and natural gas energy production in 1982. Canfield Lake is $90 \mathrm{~km}$ west of the WSA (appendix 7) between the Missouri Coteau and the Missouri River. Angelo and Anderson (1983) speculated that the elevated concentrations of ammonium may be related to the higher conversion of prairie to cropland near the WSA. Use of anhydrous $\mathrm{NH}_{3}$ fertilizers in agricultural practices in eastern North Dakota and the appearance of ammonium in the WSA precipitation coincide with typical timing of fall fertilizer application (fig. 6). Likewise, elevated levels of manganese (Mn) at the WSA relative to sites in western North Dakota (Park North, Park South, and Dunn Center; appendix 7) may be because of greater soil disturbance near the WSA. Mn is a crustal element that is included in precipitation when the soil is disturbed. Only the differences in $\mathrm{Mn}$ and $\mathrm{NH}_{4}{ }^{+}$between WSA and the western sites were statistically significant $(\mathrm{p}<0.05)$ (Angelo and Anderson, 1983). 
Table 3. Concentration of ions from a rainfall sample at the Woodworth Study Area (WSA) from May to October 1982.

[At least 20 samples were tested for each compound. Concentrations are arithmetic mean concentrations in microequivalents per liter $(\mu \mathrm{eq} / \mathrm{L}) \pm$ standard error of mean concentrations. No data is indicated by nd. From Angelo and Anderson (1983, p. 20)]

\begin{tabular}{llc}
\hline Type & \multicolumn{1}{c}{ Ion } & $\begin{array}{c}\text { Concentration } \\
(\mu \text { eq/liter })\end{array}$ \\
\hline Cation & $\mathrm{NH}_{4}^{+}$ & $38.53 \pm 5.15$ \\
& $\mathrm{H}^{+}$ & $21.12 \pm 7.94$ \\
& $\mathrm{Ca}^{2+}$ & $16.08 \pm 3.32$ \\
& $\mathrm{Mg}^{2+}$ & $4.54 \pm 0.70$ \\
& $\mathrm{Na}^{+}$ & $2.03 \pm 0.45$ \\
& $\mathrm{~K}^{+}$ & $1.52 \pm 0.30$ \\
& $\mathrm{Zn}^{2+}$ & $0.42 \pm 0.20$ \\
& $\mathrm{Al}^{3+}$ & $0.70 \pm 0.22$ \\
& $\mathrm{Mn}^{2+}$ & $0.27 \pm 0.04$ \\
& $\mathrm{Fe}^{3+}$ & $0.12 \pm 0.03$ \\
& & \\
Anion & $\mathrm{SO}_{4}$ & $23.61 \pm 4.42$ \\
& $\mathrm{Cl}^{-}$ & $7.30 \pm 1.49$ \\
& $\mathrm{~F}^{-}$ & $0.48 \pm 0.13$ \\
& $\mathrm{NO}_{3}^{-}$ & $21.91 \pm 2.83$ \\
& $\mathrm{HCO}_{3}^{-}$ & $31.01 \pm 6.23$ \\
& $\mathrm{PO}_{4}^{-}$ & $1.16 \pm 0.21$ \\
\hline
\end{tabular}




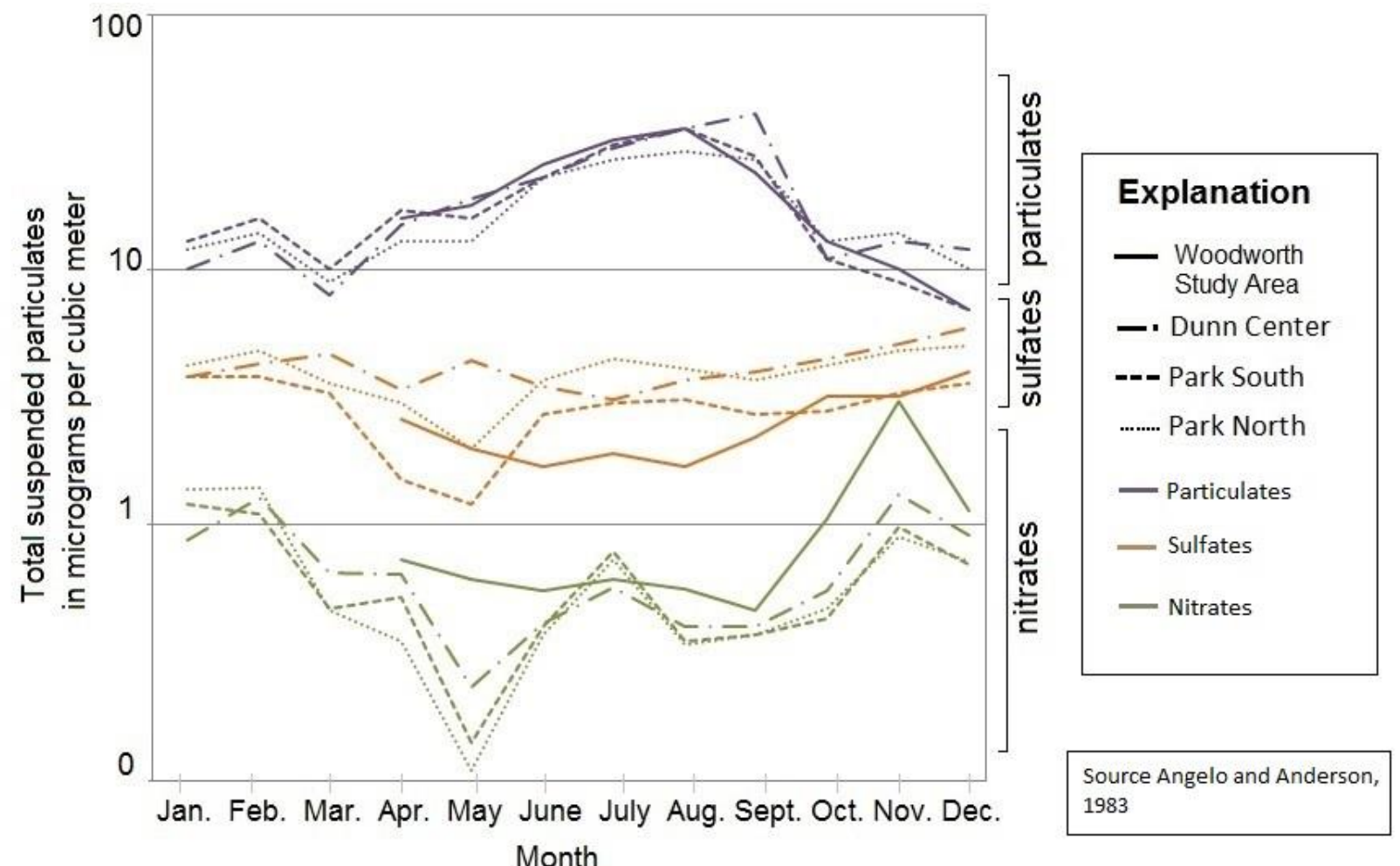

Figure 6. Monthly average concentrations of particulate pollutants at the Woodworth Study Area (WSA), Dunn Center, Park South, and Park North, North Dakota, in 1982. Locations of sampling sites are shown in appendix 7.

\section{Weather History}

Precipitation and water budgets are recognized for their importance to understanding vegetation and wetland dynamics. Data of daily total precipitation and ground cover of snow have been collected within $5 \mathrm{~km}$ of the WSA headquarters since 1951 as part of the National Weather Service Cooperative Network. In early 1965, 5 rain gages were placed in WSA fields and reported similar precipitation throughout the study area to precipitation collected in the town of Woodworth, N. Dak. In November 1965, official precipitation recording moved from the town to the headquarters building at the WSA, where daily collection of precipitation and snow cover data continued until 2005. Original copies of these data from 1959 to 1990 are available in the NPWRC archives and scanned documents from 1951 to 2005 are available from the National Oceanic and Atmospheric Administration (http://www.ncdc.noaa.gov/IPS/coop/coop.html). Daily high and low temperatures on the WSA station were recorded only for March through August of 1979 and 1980. Publications reporting long-term temperature data generally used those collected at Pettibone, N. Dak., which is $18 \mathrm{~km}$ west of the WSA. Other long-term temperature and precipitation measurements from the area were recorded in Jamestown or Napolean, N. Dak. (appendix 7) as part of the U.S. Historical Climate Network (http://cdiac.esd.ornl.gov/ epubs/ndp/ushcn/ushcn.html).

The WSA has a temperate continental climate typical of the northern Great Plains, with cold winters and warm summers (fig. 7A; Higgins and others, 1992). Winds averaged about 16 kilometers per hour and were from the northwest (Angelo and Anderson, 1983; Higgins and 
A
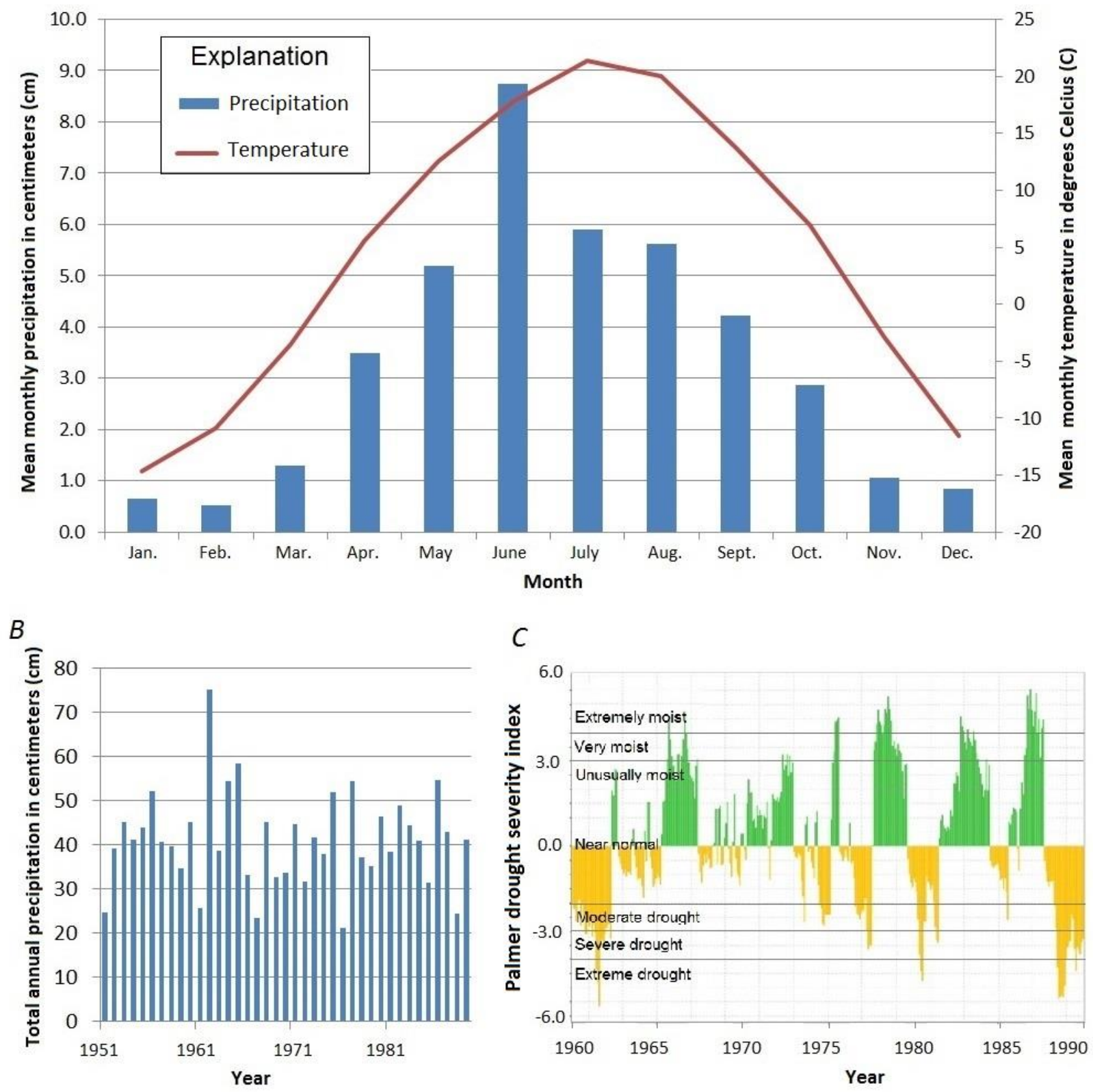

Figure 7. Precipitation, temperature, and the Palmer Drought Severity Indices (PDSI) for the Woodworth Study Area (WSA). A, Average monthly precipitation measured at or near the WSA (1963-89) and mean monthly temperature (1962-88) measured at Pettibone, North Dakota, approximately $19 \mathrm{~km}$ from the WSA (appendix 7). B, Total annual precipitation measured at or near the WSA (1951-88). C, PDSI for the south-central region of North Dakota (1960-90). 
others, 1992). Average relative humidity was 68 percent. Records from 1962 to 1988 indicate that July was the warmest month in the region, averaging $21^{\circ} \mathrm{C}$, and January was the coldest, averaging $-15^{\circ} \mathrm{C}$ (fig. $7 A$ ). Average monthly precipitation peaked in June in the form of rain (fig. 7A). There were about 120 frost-free days, from mid-May to mid-September, and an average depth of frost penetration of 1.5 m (Higgins and others, 1992; Johnson and others, 1996). Between 1951 and 1988, total annual precipitation averaged 40.9 centimeters (cm; fig. 7B). Average annual precipitation between 1963 and 1989 was similar $(40.4 \mathrm{~cm})$ and ranged from $21.3 \mathrm{~cm}$ in 1976 to $58.5 \mathrm{~cm}$ in 1965 (fig. $7 B$ ).

The Palmer Drought Severity Index (PDSI) estimates the moisture balance accounting for inputs (such as precipitation and stored soil moisture) and losses (such as potential evapotranspiration, water storage, and runoff) (Huang and others, 2011). The PDSI provides a common metric to denote seasonal and long-term trends in moisture conditions that influence wetlands and vegetation. Scores of $\pm 0-6$ indicate level of drought (-) or wet $(+)$ conditions. Data for the south-central region of North Dakota during 1960-90 indicate the WSA experienced moderate to extreme drought during its earliest years (fig. 7C). The drought of the early 1960s was followed by swings of increasing magnitude between high and low moisture (fig. 7C; National Oceanic and Atmospheric Administration, 2013).

\section{Settlement History}

Perhaps one of the most novel aspects of the WSA is the availability of land use history and concomitant social history. When lands for the WSA were acquired in the early 1960s, WSA staff members Keith Bayha and David Trauger made diligent efforts to document the land use history by interviewing local residents and mining public records for the history of each quarter section of land. Their sources included the Stutsman County Register of Deeds, files of the former Jamestown Alert newspaper, local officers of the U.S. Department of Agriculture's Soil Conservation Service and Agricultural Stabilization and Conservation Service, Service books of FWS's Area Acquisition Office, and books and direct observations by the investigators. Their results were compiled, written, and mapped by Bayha (written commun., 1963, 1964a,b). No comprehensive archaeological survey of the WSA has been completed, but Bayha (written commun, 1964a) and Mason (1938) recorded early land uses and artifacts present in the area. The NPWRC archives maintain a map of the locations of teepee ring remnants and structures created during homesteading settlement (appendix 6). The first semipermanent European settlers were livestock ranchers, some of whom built structures on the land, but nonetheless moved elsewhere when homesteaders arrived. Homesteading farmers began breaking native prairie around 1903 (fig. 8) and usually raised common flax (Linum usitatissimum) for the first 2 years (Bayha, written commun., 1964a). They also raised livestock and planted crops such as wheat (Triticum spp.) and corn (Zea mays). The Northern Pacific Railway cut through the area that is now the WSA, transporting grain, coal, passengers, and cream (Mason, 1938). The railway reached the town of Woodworth in 1912, 1 year after the town was established. The town grew to a population of nearly 300 in 1920, and nearly a century later the population had declined to less than 100 people (North Dakota State Data Center, 2000). The region remains wholly agricultural, and the main products today are soybeans (Glycine max), corn, wheat, and livestock (U.S. Department of Agriculture, 2013a). 


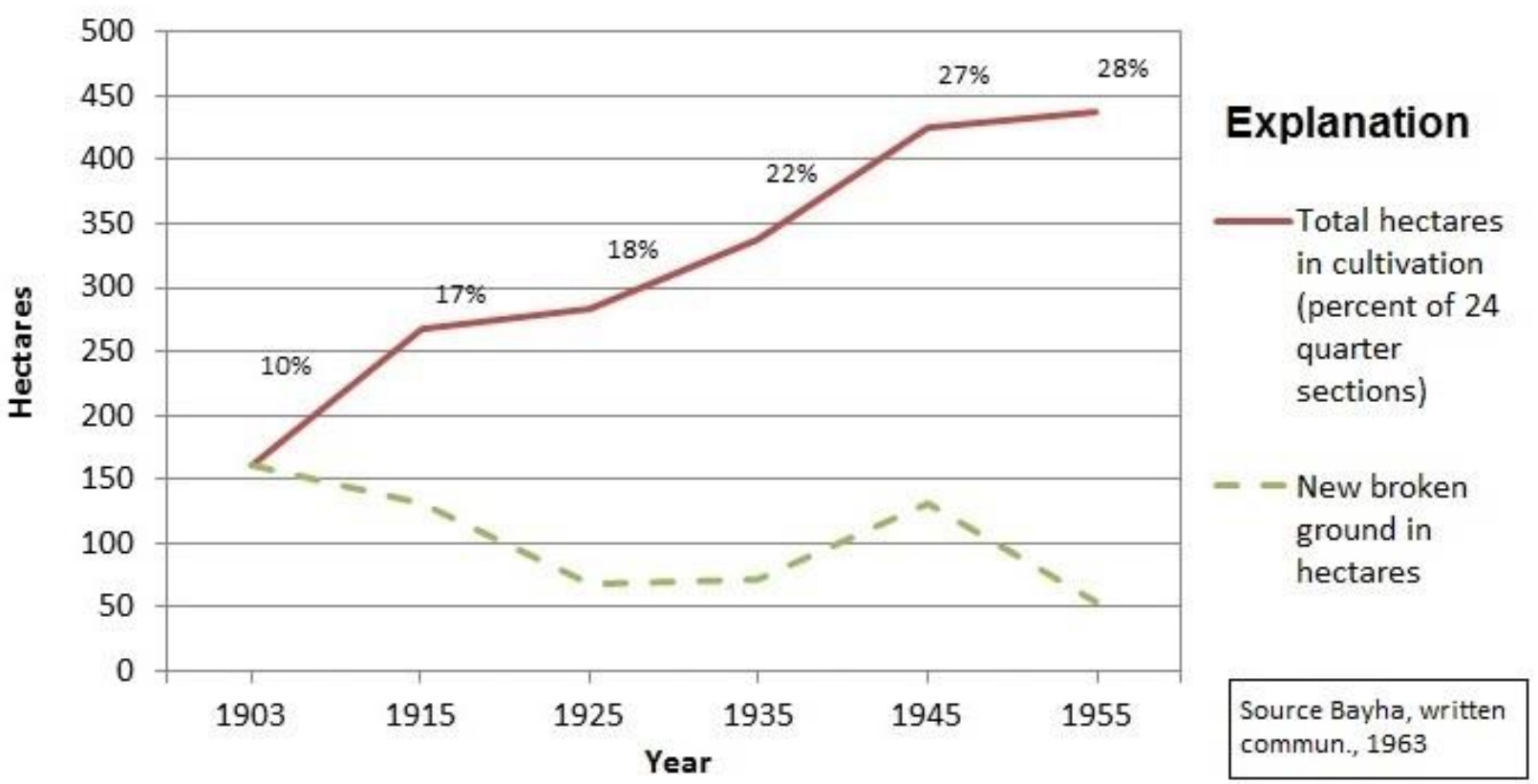

Figure 8. New broken ground and total area in cultivation of 24 quarter sections (1,550 hectares) around and including the Woodworth Study Area (WSA), 1903-55.

Social histories of the WSA and surrounding communities are preserved through Bayha's (written commun., 1964a) report as well as in documents available at institutions such as the State Historical Society of North Dakota (http://history.nd.gov/archives/index.html). Staff at CLWMD also compiled a small historical library. Social or cultural data are an often overlooked aspect of land use change (Higgs, 1997; Foster and others, 2003), but the resources available to the WSA offer an interesting opportunity for historical ecologists (Balée, 2006).

\section{Management History}

\section{General Land Use History}

Much of the WSA is remnant native prairie, although one-third of the area has a history of cultivation (Bayha, written commun. 1963, 1964a,b). The main road running east and west through the WSA serves as a general border between 2 historical land uses. North of the road, the soil is capable of cultivation (appendix 4), and much of that land has a history of agriculture. Land south of the road contains predominately native prairie and the soil is lower quality for cultivation. The first land acquisitions for the WSA were lands composed of 2 farms (referenced as the Eddy and Fish tracts; appendix 3). Appendix 1 contains the histories of each tract of land and the year acquired by the FWS or used for data collection. Physical features of the land look much the same as when it was managed by homesteaders with only minor changes. In addition to the wetland work and gravel pits already discussed, WSA staff planted or replanted 4 tree shelterbelts (appendix 6). A 12-row shelterbelt was planted west of the WSA headquarters in 1965. A second shelterbelt site was planted several meters north and west of this shelterbelt the following spring, and in 1970, an even larger shelterbelt was planted north and west of those plantings. Nearby willow trees growing along the station entrance road were cut to prevent snow 
drift across the road. A fourth grove of trees was replanted in $19670.75 \mathrm{~km}$ southeast of headquarters on a former homesteading site. The gravel mining company in the northeast corner of the WSA filled in the gravel pits and built an airstrip on the site in 1948 (Woodworth Betterment Community, 1986, p. 40). A geographic information systems (GIS) layer of shelterbelts, known structures, and remnants on the WSA is available from the NPWRC (appendixes 6 and 8).

\section{Habitat Management}

The WSA is divided into 24 units of which 17 units $(1-4,6-9,9 A, 11-13,15-18,22)$ are under federal management (fig. 9). The study units are numbered arbitrarily, although they largely follow quarter section lines and run boustrophedonically, following the conventions of township sections (appendix 6). Correspondingly, most study units are 64.7 ha (160 acres). Although a study unit and a quarter section are largely interchangeable in size, for this report, study unit refers to the WSA labeling system (fig. 9) and quarter section refers to all other geographical references. The WSA contains all or part of 6 township sections. Plat information is listed in appendix 3. Initially, WSA staff used wetlands as the basic unit of study, and thus each wetland was assigned a number within its quarter (for example, 7-10 was wetland 7 within study unit 10), but in 1967 the basic study unit was increased to the quarter section. However, because initial homesteaders worked around the many changes in soil, elevation, and wetlands, actual land use was heterogeneous within a quarter section. Furthermore, most of the federal land management and land use took place at a unit smaller than a quarter section. Hence, we use field as the current land use unit because land within a field has the same land use history and follows many natural boundaries, such as wetlands and soils. A study unit may contain as many as 12 fields. Fields are labeled numerically within each study unit starting at 1 (fig. 9).

The proportional land use of each study unit at the time of federal acquisition is shown in figure 10. Cultivation dominated study units 1, 2, 3, 6, and 7 in the north and 17 in the south, whereas native vegetation dominated land use in study unit 9, which entirely overlays an area of glacial stagnation outwash, and study units 11-15 and 18-22 in the south. Most study units had at least a small native field, and all had wetlands. Study unit 12 contained a farmstead and at the time of acquisition by FWS had more than 50 percent native cover, but that study unit was converted to the headquarters for the WSA, and later for the CLWMD.

During the first 5 years of the WSA, the land was managed in line with previous private management. During this time, the WSA was mapped and characterized (Bayha, written commun., 1963, 1964a,b), and staff developed new monitoring techniques for waterfowl surveys and nesting studies (Higgins and Woodward, 1996). Several years of habitat manipulation

followed, which was applied and recorded on the field scale (fig. 11). Widespread grazing in the early years gave way to prescribed burns and seeding by the 1970s (fig. 11). 


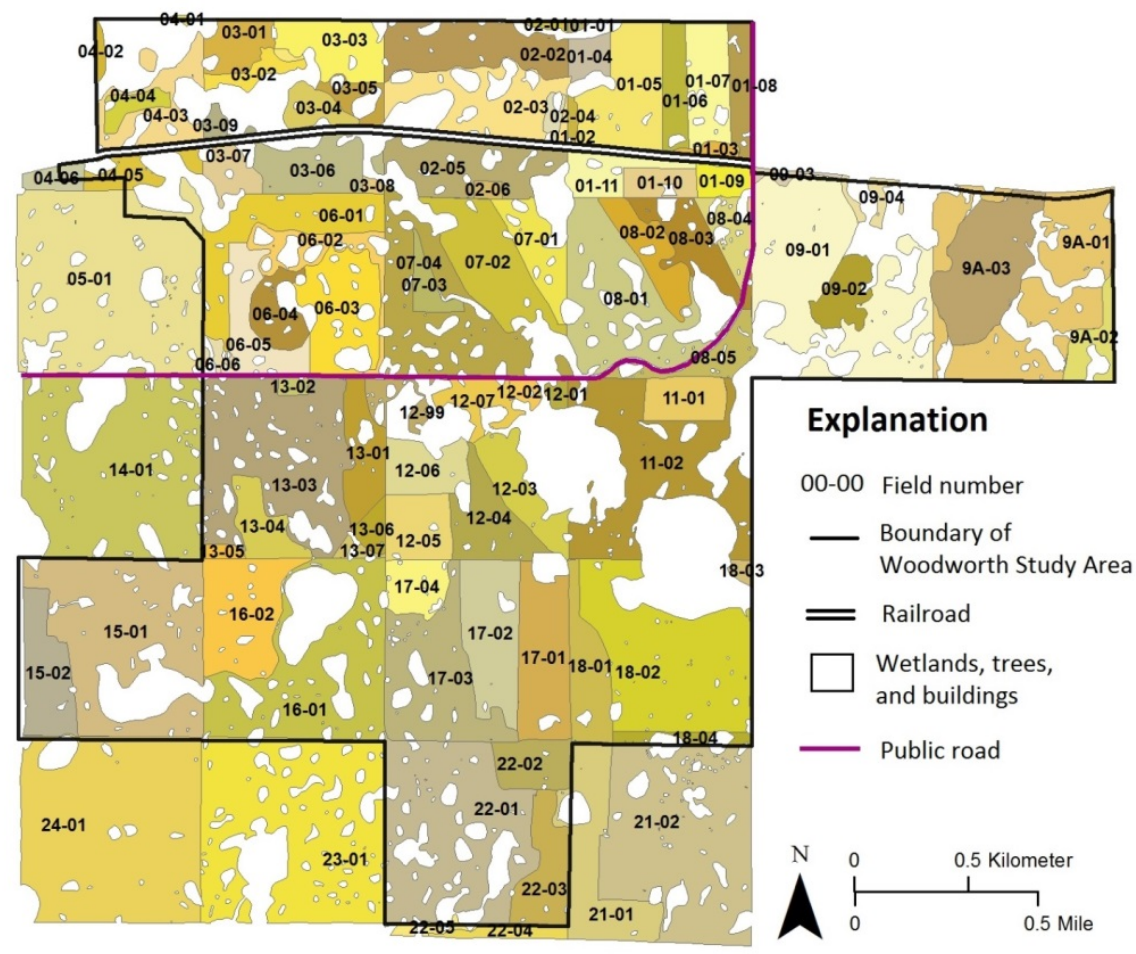

Figure 9. Numbered study units and fields at the Woodworth Study Area (WSA). Field colors are for illustration purposes only.

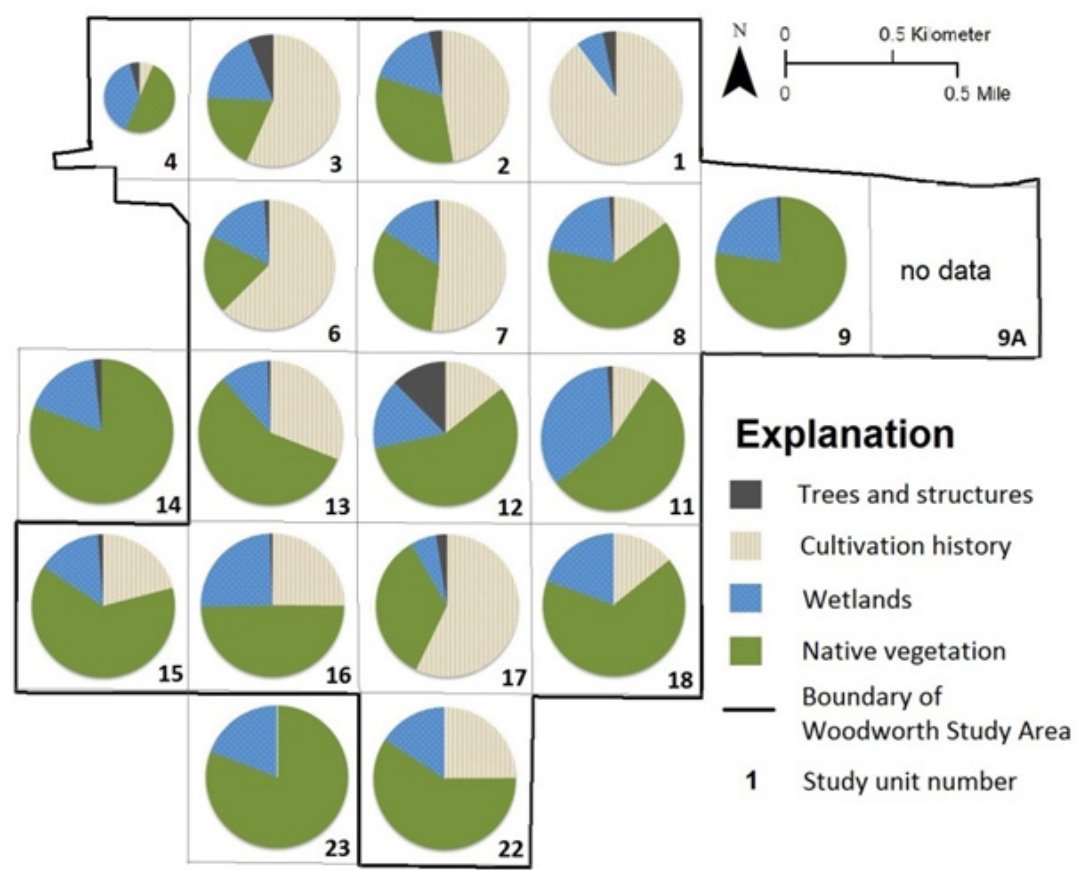

Figure 10. Land use at the time of federal acquisition or agreement to use on the Woodworth Study Area (WSA), by study unit. 


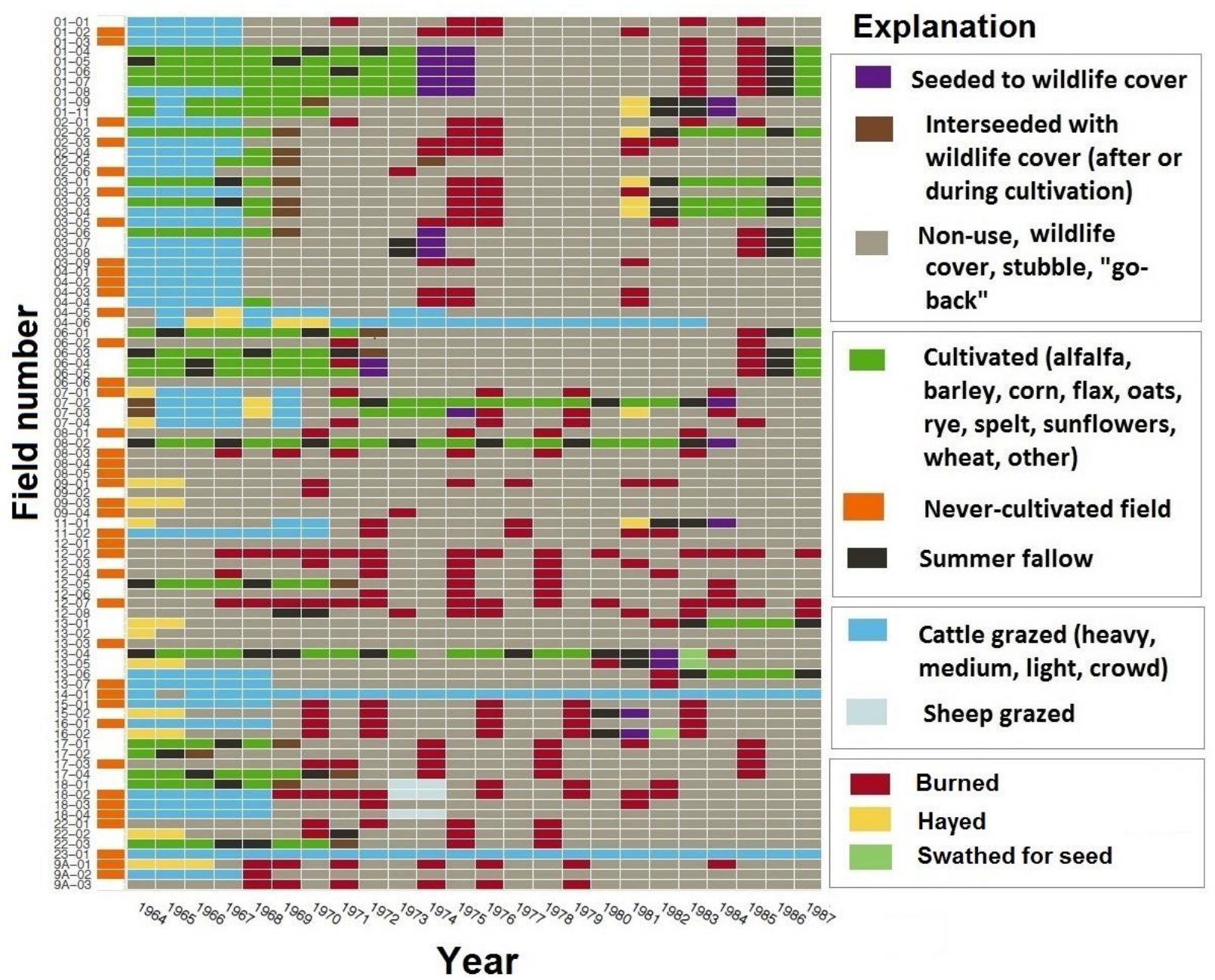

Figure 11. Land uses and treatments for all fields on the Woodworth Study Area (WSA) during 1964-87.

Some of the management practices illustrated in figure 11 can be difficult to define precisely. To facilitate analysis and synthesis, the working definition of land treatments applied at the WSA and the resulting land cover are described in table 4. The definitions follow Kantrud and Higgins's (1992) convention of distinguishing land use and land treatment based on time. For example, fallow refers to idling tilled land during a growing season; this was a common crop rotation practiced in the PPR through the 1960s. The lack of vegetative cover makes fallow fields subject to erosion or soil loss (Gleason and Euliss, 1996), so a field is generally left fallow for only one season in preparation for seeding in crops or nesting cover. Therefore, fallow is a shortterm treatment that can be applied to fields of various land uses or cover (such as a long-term pasture or cultivated field). Three other treatments that were commonly applied at the WSA were prescribed burning, seeding, and grazing. 
Table 4. Working definitions of actions applied to land at the Woodworth Study Area (WSA).

[Actions are land management treatments or experimental activities applied at WSA. Definitions are gleaned from WSA reports, publications, and unpublished memos, and summarize the action as used at the WSA.]

\begin{tabular}{ll}
\hline \multicolumn{1}{c}{ Action } & \multicolumn{1}{c}{ Definition } \\
\hline Burned & Prescribed, accidental, or wildfire. \\
Cropland & Cultivated or hayed broken field. \\
Fallow & Cropland, then idled for one season. \\
Old field succession or "go-back" & Pre-1960s cropland, which was idled for more than one season. \\
Grazed & Grazed with sheep or cattle in low, medium, high, or crowd-grazed intensities. \\
Man-made & Buildings, dams, or shelterbelts. \\
Native prairie & Never cultivated. \\
Tame or seeded grassland & Seeded with domestic forage or nesting cover. \\
\hline
\end{tabular}

Burning

Burning was a management tool developed and regularly applied at the WSA. The prescribed burning work during the 1960s and 1970s (fig. 11) provided new information on its use in maintaining optimum grassland conditions for nesting waterfowl, other migratory bird species, and resident wildlife species. The research and demonstrations were instrumental in leading FWS to embrace fire as a valuable management tool (for example, Higgins and others, 1989a). More than 200 separate burns were recorded from 1965 to 1984 on the WSA; the vast majority was prescribed, but 5 were wild fires or accidentally caused. Data include field location, date, time, weather, and logistical information. Areas from 0.4 to 65 ha were burned at one time, and the average burn covered 12 ha. Most fires occurred in the spring but timing ranged from February to November (fig. 12). The frequency of burns of a particular field varied. Several patterns of frequency emerge from figure 12, including many repeated fires, sporadic fires, and never burned under federal management. For example, fields 12-2 and 12-7 received yearly burns, whereas some fields in study units 15 and 16 received burns every 2-4 years (fig. 11). Maps of prescribed burns by year and a GIS layer of fire breaks, such as trails and roads, are available in the NPWRC archives. From 30 to $50 \mathrm{~km}$ of bare-soil fire breaks were tilled several times per season, but a few fire breaks established on section lines were graded rather than tilled.

Aside from research studies, prescribed burns were applied for other purposes, such as to stimulate seed head production on wild rye (Elymus sp.) for a harvestable seed crop, to evaluate effects on cattails (Typha sp.), or to remove annual weed seeds. For example, a 1977 memo (Kirsch, L., written commun.) notes that a treatment plot with 3 prescribed burns at 3-year intervals concurrent with dry weather reduced cover of non-native grasses by more than 90 percent, whereas cover of native grasses increased more than 70 percent. In a control plot over the same period, native grass cover decreased 31 percent, whereas non-native grass cover increased 14 percent. 


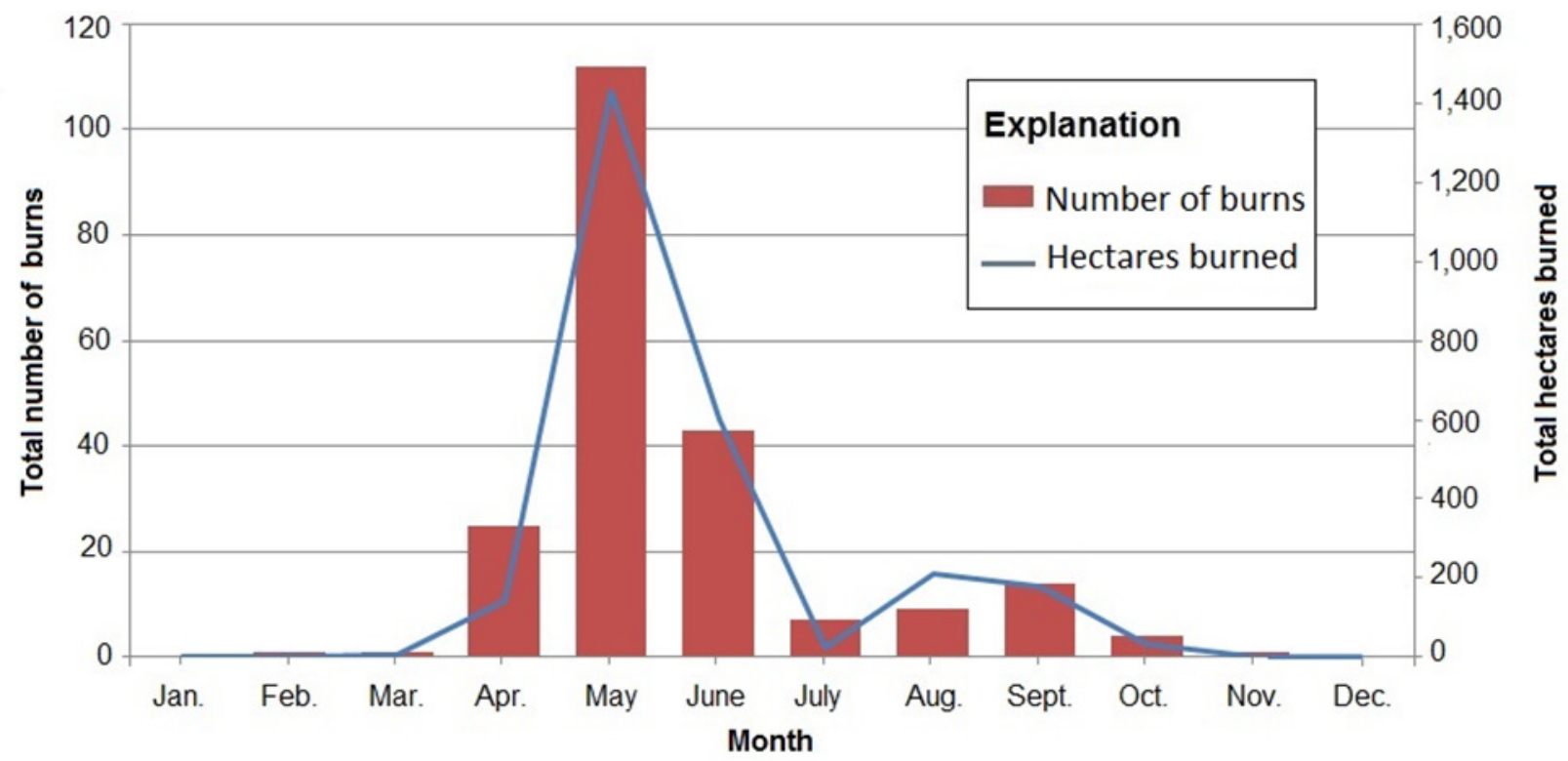

Figure 12. Total number and hectares of prescribed burns per month at the Woodworth Study Area (WSA) during 1965-84.

WSA staff published reports on various aspects of fires based on experience at the WSA, including guidelines (Higgins and others, 1989a), management reviews (Higgins and others, 1989b), effects on breeding birds (Johnson, 1976), fires caused by lightning (Higgins, 1984), fires that did not go as planned (Higgins, 1978), and effects on vegetation and wildlife (Kirsch and Kruse, 1973; Kirsch and Higgins, 1976; Kirsch, 1978).

\section{Seeding}

Another treatment often applied at the WSA was seeding cover. Seeding a tilled field to create nesting cover is variably referred to as wildlife cover, tall dense rank cover, or dense nesting cover by state and federal wildlife agencies. However, the same field may be called forage or tame hayland by farmers and ranchers, or land retirement cover or wildlife cover plantings by agriculture agencies (Higgins and Barker, 1982). The WSA records generally use the wildlife terms but also use tame hayland term.

Seeded fields shared a history of cultivation occurring either before the 1960s (fields that had become tame hay or "go-back" fields by the time of federal management; fig. 11) or after the 1960s (considered cultivated fields; fig. 11). The NPWRC archives document specific seed combinations for some fields, such as in field 3-6. This field was first broken around 1910 (Bayha, written commun., 1964a) and had regular cultivation until the early 1970s (fig. 11). The standard preparation for a field was to plow it in the fall and leave it fallow the following summer to kill aboveground vegetation and rhizomes (Higgins and Duebbert, 1982). After a year of summer fallow, field 3-6 was seeded in June 1974 to a mixture of wheat and other seeds to create tall, dense, rank cover. The seeding mixtures for this and 3 other fields are listed in table 5. 
Table 5. Seeding mixtures used on a sample of fields at the Woodworth Study Area (WSA).

[Study units refer to the location, following WSA convention, which contained the field that was planted. All values of seeding mixtures are in kilograms per hectare $(\mathrm{kg} / \mathrm{ha})$, with pounds per acre (lb/ac) in parentheses. Wheat was also included in the mix for some fields.]

\begin{tabular}{|c|c|c|c|c|}
\hline Species & $\begin{array}{l}\text { Study unit } 1 \\
{[\mathrm{~kg} / \mathrm{ha} \text { (lb/ac)] }}\end{array}$ & $\begin{array}{l}\text { Study unit } 2 \\
{[\mathrm{~kg} / \mathrm{ha}(\mathrm{lb} / \mathrm{ac})]}\end{array}$ & $\begin{array}{l}\text { Study unit } 3 \\
\text { [kg/ha (lb/ac)] }\end{array}$ & $\begin{array}{l}\text { Study unit } 6 \\
\text { [kg/ha (Ib/ac)] }\end{array}$ \\
\hline Date seeded & August 19, 1974 & June 3, 1974 & June 3, 1974 & May 1972 \\
\hline $\begin{array}{l}\text { Intermediate wheatgrass } \\
\text { Thinopyrum intermedium }\end{array}$ & $6.7(6)$ & $4.5(4)$ & $4.5(4)$ & $6.7(6)$ \\
\hline $\begin{array}{l}\text { Tall wheatgrass } \\
\text { Thinopyrum ponticum }\end{array}$ & $2.2(2)$ & $4.5(4)$ & $4.5(4)$ & $3.4(3)$ \\
\hline $\begin{array}{l}\text { Alfalfa } \\
\text { Medicago sativa }\end{array}$ & $2.2(2)$ & $1.1(1)$ & $1.1(1)$ & $2.2(2)$ \\
\hline $\begin{array}{l}\text { Yellow sweetclover } \\
\text { Melilotus officinalis }\end{array}$ & $1.1(1)$ & $1.1(1)$ & $1.1(1)$ & $2.8(2.5)$ \\
\hline
\end{tabular}

Several studies of grassland establishment were conducted at the WSA with a focus on how to establish wildlife cover using appropriate seed mixtures and techniques. Jacobson and others (1994) seeded a 12-ha field at the WSA in 1981 using "sculpted” seeding, which planted seeds according to changes in soil and topography; Higgins and Duebbert (1982) reported on the seed bed preparation for this field. Duebbert and others (1981) published a comprehensive seeding guide for managers throughout the glaciated PPR and presented a review of this topic (Duebbert, 1983), as well as a proceedings paper (Duebbert, 1987). The NPWRC also published a pamphlet on seeding methods for wider distribution to the public (Meyer, 1987).

Meyer (1996) recorded that "by 1970, more than 200 ha of former cropland were seeded into mostly non-native, cool-season grasses and legumes. The primary grass species were intermediate wheatgrass (Thinopyrum intermedium), tall wheatgrass (Thinopyrum ponticum) and slender wheatgrass (Elymus trachycaulus), and the legumes were alfalfa (Medicago sativa) and yellow sweetclover (Melilotus officinalis). Two fields were seeded into basin wild rye (Leymus cinereus)." Meyer (1996) also reported that the WSA hosted experiments of "native grass seedings during the mid-1970s. About 15 percent of the area was seeded with native grasses by 1980. The principal cool-season species were green needlegrass (Nassella viridula) and western wheatgrass (Pascopyrum smithii). Some fields were over-seeded with warm season species including switchgrass (Panicum virgatum), big bluestem (Andropogon gerardii), and Indian grass (Sorghastrum nutans).”

The combination of intermediate wheatgrass, tall wheatgrass, alfalfa, and sweetclover was planted at the WSA because these species were relatively easy to establish and they created good habitat for nesting ducks (Duebbert and others, 1981). This species combination was adaptable to many soils and conditions throughout the PPR and could enhance the soil when used in rotation with tillage (Duebbert and others, 1981). Cool-season plants, such as tall and intermediate wheatgrasses, were in general easier to establish than native, warm season grasses even though they need rejuvenation sooner than native species. For example, intermediate wheatgrass deteriorates in height, density, and vigor after 8-10 years (Duebbert and others, 1981).

Higgins and others (1984) discussed 3 fields that were seeded to native grasses in 1981 and 1982. In the publication, they refer to fields 1, 2, and 3 (equivalent to WSA conventions fields 15-2, 16-2, and 13-4, respectively; figs. 9, 11). After leaving the fields in summer fallow, 
the fields were seeded the following year to a combination of cool- and warm-season grasses. The fields were then subjected to a burning, swathing, or herbicide regime (see Higgins and others, 1984, for details). The costs of re-seeding a field were offset by harvesting seeds from existing WSA fields (for example, study unit 16 in 1982) and proceeds from crop-sharing and grazing agreements with local producers.

\section{Grazing and Agriculture}

Cattle and sheep historically grazed on the WSA before and during federal management (Bayha, written commun., 1964a, b; fig. 11). Grazing by cattle was recorded on almost one-half of the fields in the 1960s (fig. 11), and the intensity was classified as heavy, moderate or light. Kirsch (1969) gave one early definition of those terms at the WSA; grazing intensity was judged by residual vegetation left in the spring before new growth commenced. If two-thirds of the vegetation remained, the pasture was classified as lightly grazed. Between one-third and twothirds remaining was moderate, and less than one-third remaining was heavily grazed. At the WSA, light, moderate, and heavy grazing corresponded to 1 animal unit month per 6 acres (2.4 ha), 1.35 acres (0.55 ha), and 1.0 acre (0.4 ha), respectively (Kirsch, 1969). Grazing records for the WSA are in hardcopy, primarily in the form of contracts and receipts from private producers. WSA researchers analyzed grazing effects on upland nesting waterfowl pair numbers, nesting densities, and nest success (Kirsch, 1969), and waterfowl distribution, abundance, and productivity (Kirsch and others, 1978). However, little to no analysis has been conducted on the effects of cattle grazing on the vegetation. The general effects of grazing and burning on prairie wetlands were reviewed by Kantrud (1986).

Sheep grazing is noted in a 1973 memo (L. Kirsch, written commun., 1973), which recorded sheep on nearly the entire study unit 18 . Under contract with a livestock owner, about 550 sheep and lambs were pastured in study unit 18 from July 29 to October 1, 1973. WSA staff recorded qualitative descriptions of vegetation during sheep grazing. The sheep were noted as patchy eaters, cutting grass short in places and leaving other areas untouched. Forbs were heavily browsed, and sheep preferred alfalfa after the rains started in mid-August. The following spring, 450 ewes and 650 lambs were again grazed on this unit from late May to mid-July 1974 (fig. 11), and the effects were described in various memos.

In addition to qualitative descriptions, researchers also conducted controlled experiments of sheep's effect on vegetation. Four controlled plots were placed in study unit 18 for enclosure/exclosure experiments (appendix 8), and stem counts were recorded in 1973 and 1975. Researchers were particularly interested in the effects of sheep browsing on wolfberry (Symphoricarpos occidentalis), silverberry (Elaeagnus commutata), and Wood's rose (Rosa woodsii).

\section{Chemicals}

Chemicals and fertilizers have been applied periodically both for land management and experimental reasons. For land management, Banvel ${ }^{\circledR}$ (dicamba) was used for treatment of leafy spurge (Euphorbia esula) at 7 points across the WSA (fig. 13). Knapweed (Centaurea sp.) was treated with consecutive years of Tordon ${ }^{\circledR}$ (picloram), Banvel ${ }^{\circledR}$, and 2,4-D (2,4Dichlorophenoxyacetic acid) applications along with aggressive weeding. No records were apparently kept on the outcomes of these efforts. 


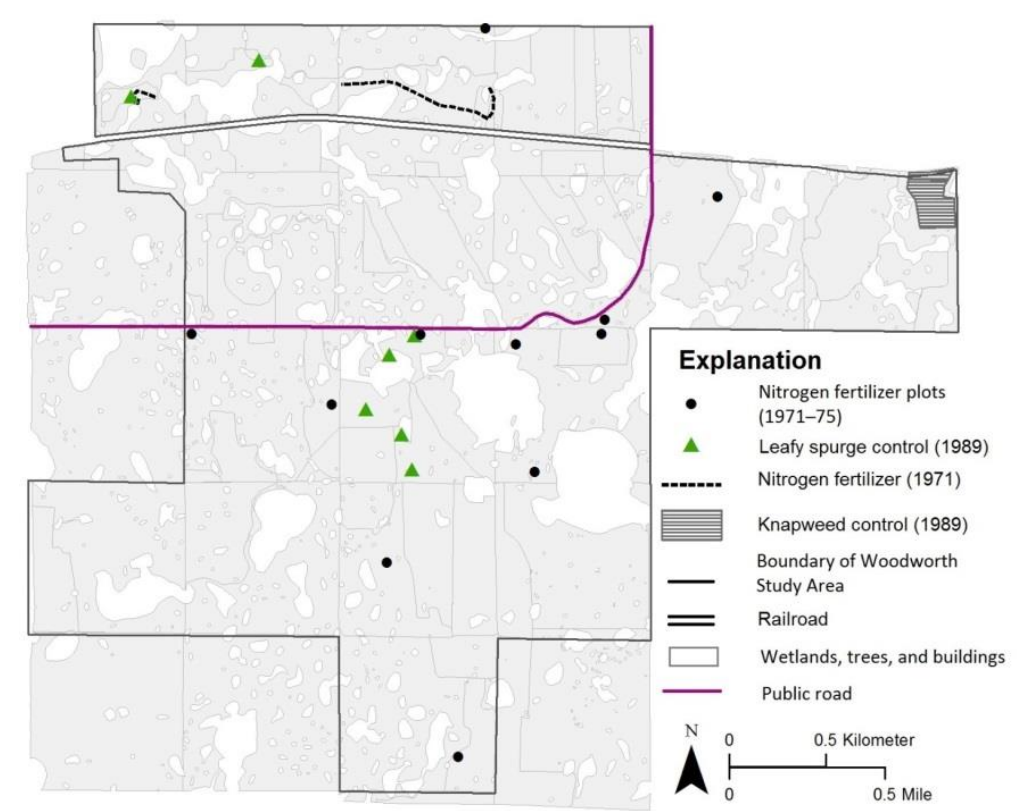

Figure 13. Location of chemical treatments for control of undesirable species and fertilization on the Woodworth Study Area (WSA). The background map is delineated into functional fields which share a homogenous land-use history.

Seeding a field after a summer fallow offered weeds opportunities to take hold. Plants such as lambquarters (Chenopodium album), annual marshelder (Iva annua), absinth wormwood (Artemisia absinthium), and field bindweed (Convolvulus arvensis) were sprayed several times with 2,4-D to stop their establishment in new fields (Higgins and Duebbert, 1982).

Experimental applications of fertilizers were tested on the WSA from 1971 to 1975 (appendix 9; fig. 13) to expand on results from nearby research plots of the U.S. Department of Agriculture. Lorenz and Rogler (1971) reported that semiarid grasslands of the Northern Plains did not appear to be primarily limited by soil moisture, and that nitrogen application increased forage production on seeded or native prairie. Soon after, WSA researchers similarly tested the use of nitrogen fertilizer in 11 native and seeded plots (fig. 13). The plots were placed throughout the WSA from high ridge to low prairie (fig. 13). Treatments were also stratified by plot treatments of grazing, burning, and an idled control plot. Each of the 11 plots was divided into 7 strips and 7 controls. Nitrogen (34-0-0) was applied once in spring 1971 to each of the 7 treatment strips with the plots at rates of 56-673 kg per hectare. Researchers revisited the plots in late summer from 1971 to 1975 and measured the average height of vegetation crowns of grass and percent cover of plant species. Results from the tests are reported only as unpublished data belonging to K.F. Higgins in Duebbert and others (1981, p. 19). The report states that preliminary analysis indicated a significant difference in crown height between fertilized and control plots. Furthermore, nitrogen treatments of less than $112 \mathrm{~kg} / \mathrm{ha}$ increased plant height for 1-2 years, whereas applications of 280-673 kg per hectare increased grass height for 3-5 years, generally relative to the amount applied.

In treatments separate from that unpublished test, nitrogen fertilizers were applied to isolated strips of land in study units 2 and 4 in 1971 at a rate of $280 \mathrm{~kg} / \mathrm{ha}$ (dashed line in fig. 13). Nitrogen, phosphorous, and potassium were also applied to select fields from 1969 to 1975 (appendix 9). 


\section{Vegetation Surveys}

\section{General Vegetation Description}

In the post-glacial landscape, grassland vegetation was a product of increased aridity, greater frequency of drought, ensuing fires, and intermittent foraging and trampling from herbivores. These factors kept shrubs and trees sparse, although they occur throughout the grasslands, implying that aridity is not the limiting factor for trees and shrubs (Axlerod, 1985). The WSA and, more broadly the Missouri Coteau, are in the mixed-grass prairie, which is botanically distinct from the tallgrass prairie to the east and shortgrass prairie to the west. The grasslands of the northern Great Plains have few endemic taxa and most occur near borders with other ecosystems (Axlerod, 1985). Axlerod (1985) attributed these patterns of endemism of grassland plants to the relatively young landscape compared to bordering forest or desert biomes.

The WSA lies at an important location for measuring plant biodiversity because a greater variety of species grow where there is topographic variation (Coupland, 1979). Woody vegetation at the WSA is patchy because of the hummocky topography and occurs in thickets where soil and slope are discontinuous. Distinct data collections of upland vegetation include an initial survey of vegetation (1963), vegetation structure (1974-89), 2 sets of upland plant transects (1966-84 and 1979-81), plant phenology (1979-84), and photograph stations (197089). A list of the 450 plant species present in the WSA from 1966 to 1989 is in appendix 10. This list is cumulative and was compiled from unique plant species noted in several surveys. The NPWRC herbaria collections contain 191 samples of plants collected at the WSA (appendix 11). Publications that used these datasets are in appendix 2. Note that no data were collected for biomass or other measures of aboveground productivity.

\section{Early Studies}

Early studies of the area's vegetation were modeled after those conducted by the FWS in Canadian parkland areas of Alberta and Saskatchewan (Higgins and others, 1992). Studies were largely qualitative or observational in nature. In 1963 and 1964, baseline surveys of the WSA wildlife, vegetation types, water, and physical characteristics were conducted (Bayha, written commun., 1964b). In the first year, those surveys included 583 ha of federal land and 85 ha of private land, and in the second year they included 1,554 ha (Bayha, written commun., 1964b). A field inspection of plant species composition was used to map partial land use history and vegetative characteristics present in 1963, and the complete WSA in 1964 (fig. 14, from Bayha, written commun., 1964b). Vegetation around wetlands was characterized according to principal species and abundances. These data are available in hardcopy in the NPWRC archives. Nonnative fields were characterized by the dominant use or cover as hayed, grazed, cultivated, or not used (fig. 11). Native prairie was further surveyed by establishing transects in 1963 (fig. 15). Native fields were categorized at each ten-step interval along the transects as upland prairie, slope prairie, lowland prairie, or brush (fig. 16). Plant species were also recorded at the intervals

and were reported in Bayha (written commun., 1963, 1964b) along with qualitative abundance values (fig. 16). These data provide an early documentation of species distribution by topographic location. 


\section{Long-term Vegetation Transects}

An accidental burn during 1966 on the WSA resulted in noticeably increased growth of desirable grass species. Transects were established to test whether prescribed fire could be a management tool for prairie vegetation composition, and this was expanded to test additional treatments such as grazing, haying, or nonuse. The first systematic and quantitative vegetative surveys at the WSA were conducted by R. E. Stewart and L. Kirsch on November 23, 1966. Two transects were created initially: 1 in the northeast corner of study unit 8 and the second in study unit 12 (fig. 15). Five additional transects were established in 1968, 2 of which were discontinued in 1972 (fig. 15). As many as 13 transects were established, although a maximum of 12 were surveyed in any 1 year (fig. 15). Transects ranged from $215 \mathrm{~m}$ to $425 \mathrm{~m}$ long and included 7-14 sampling points or "stations." The fields containing transects were mostly upland, native grassland sites, but 1 was on a "go-back" field, and several stations were in or near wetlands.

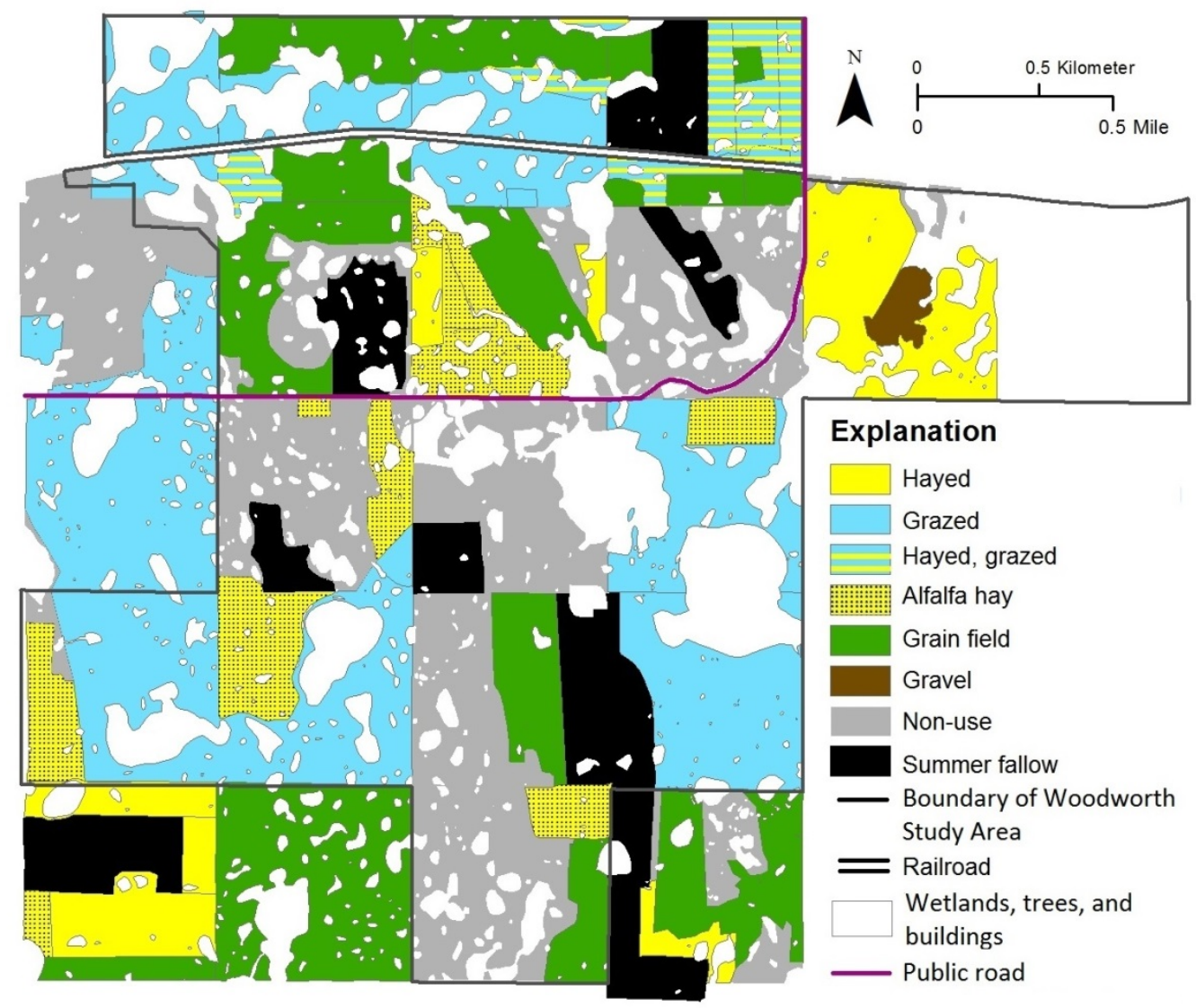

Figure 14. Land uses of the Woodworth Study Area (WSA) under federal management in 1964. Digitized from figure 10 in Bayha (written commun., 1964b). 


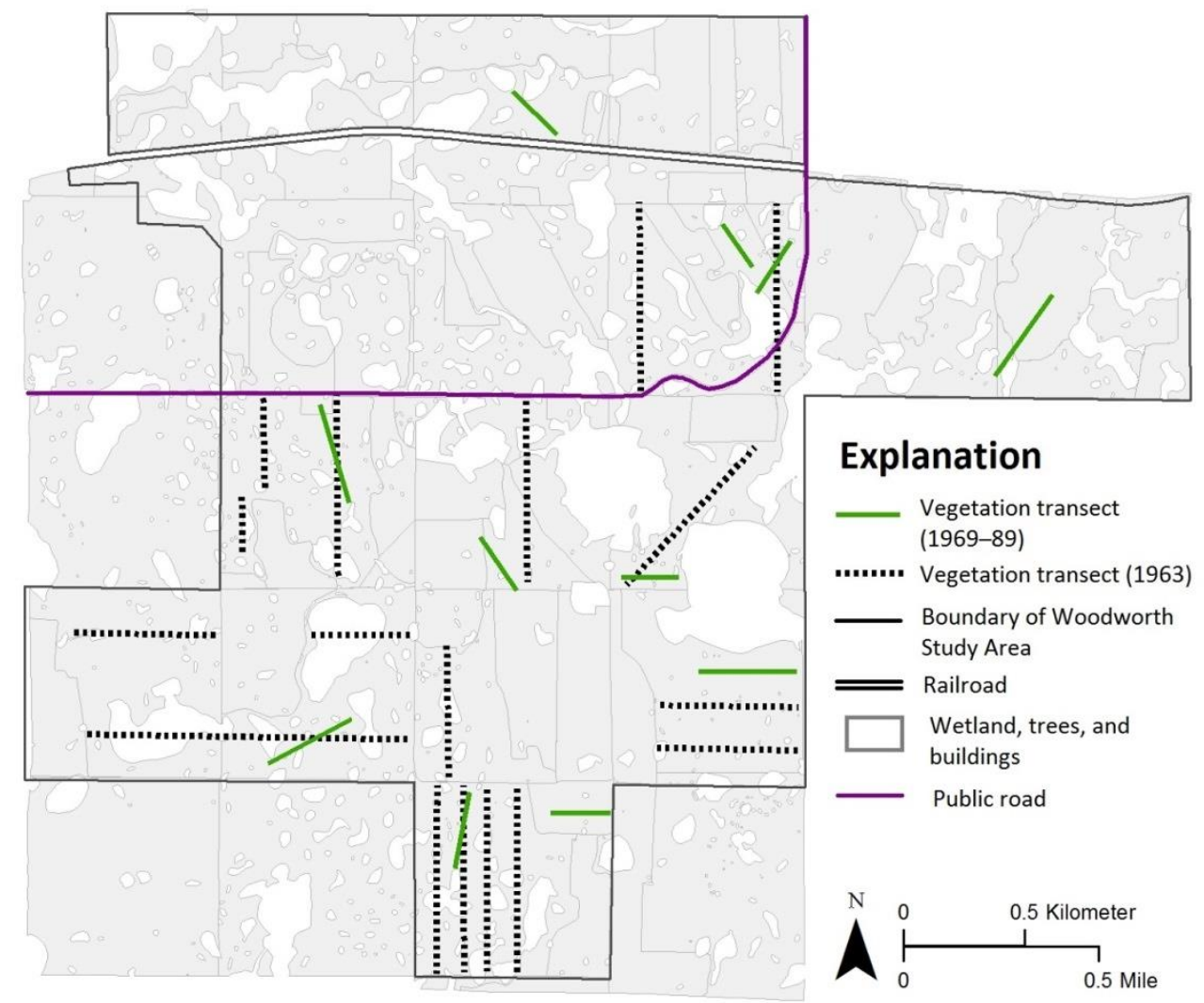

Figure 15. Locations of long-term vegetation transects (1966-89) and early vegetation transects (1963). The background map is delineated into functional fields which share a homogenous land-use history.

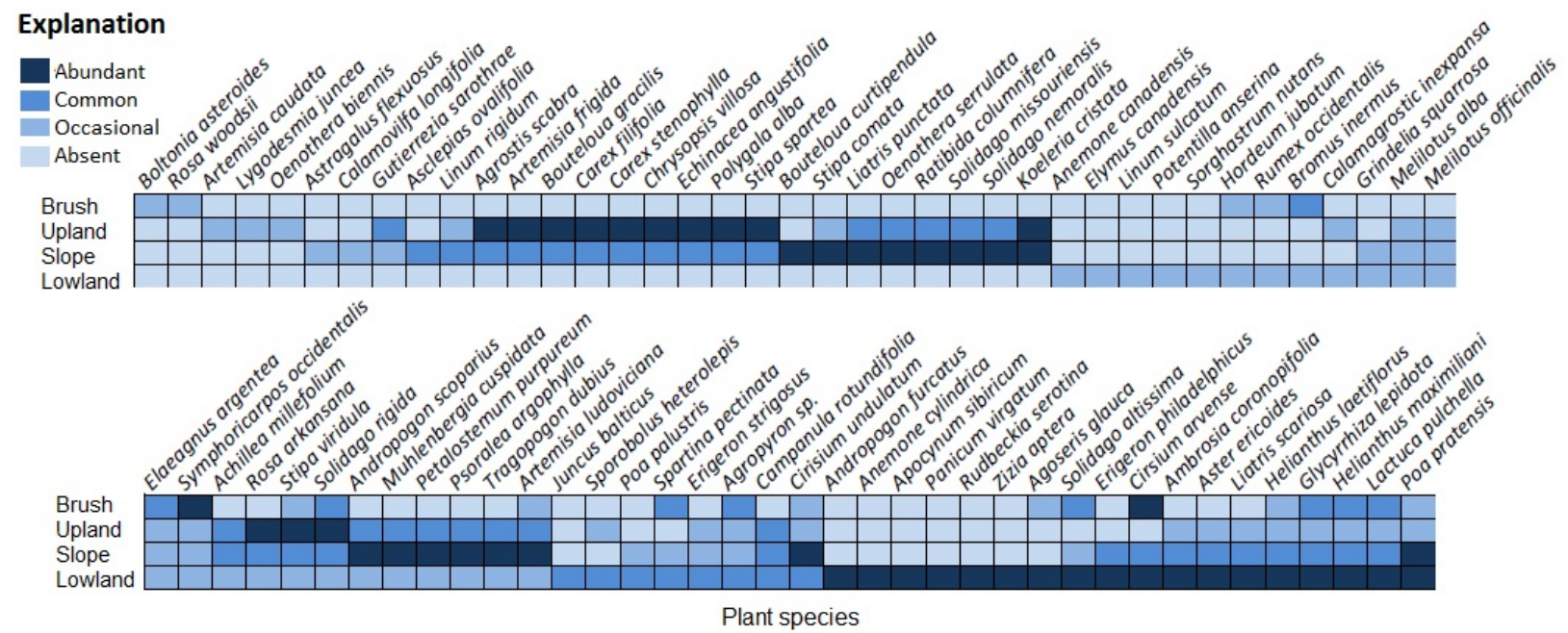

Figure 16. Relative abundance of plant species surveyed in native fields at the Woodworth Study Area (WSA) in 1963, by their location in brush, upland, slope, or lowland areas. 
Stations were surveyed once per year in summer or fall (Johnson and others, 1996). The methods generally followed the Daubenmire (1959) method, using a $1.5 \mathrm{~m} \times 1.5 \mathrm{~m}$ quadrat. Vegetation was recorded by aerial coverage of each species based on percent coverage levels of less than 5, 5-25, 25-50, 50-75, 75-95, and 95-100. Environmental data recorded at each station included soil type, moisture, slope, and aspect, as well as land uses such as grazing, idle, or burning. The end points of the transects were physically marked using steel t-posts. From 1966 to 1972, the sampling stations were located by counting paces. In 1973, the individual stations were permanently marked by a 1-inch diameter pipe. These were pounded flush to the ground to prevent chain drags from catching (K.H. Higgins, oral commun., 2014). Hence, the number of stations in each transect was consistent during 1973-89, and station data may be compared year to year. Data are available from the initial survey in 1966 through August 16, 1989, when regular transect surveys were discontinued. Johnson (written commun., 1982) summarized methods and data collected from 1966 to 1982 in an unpublished report. About 230 plant species were identified on the transects during that time, and since Johnson's analysis, more than 25 new species were identified on the transects (fig. 17).

Johnson (written commun., 1982) discussed challenges of this dataset and study design, such as plant data being inherently non-independent from 1 year to the next because some grassland plants persist perennially. Annual differences in staff and volunteers conducting the surveys may have introduced some inconsistencies, although this information is recorded and available for 1966-81. Inconsistent sampling dates (May to November; fig. 18) may introduce some longitudinal inconsistencies into the dataset. Finally, the design of the long-term transects is unbalanced in terms of number of replicates per treatment (Johnson, written commun., 1982).

Data from 4 of the 13 transects were reported by Kirsch and Kruse (1973), but other than Johnson's unpublished report (written commun., 1982), vegetation data from these long-term transects have not been summarized or analyzed before this report. Digital data and paper copies of the original data are available in the NPWRC archives.

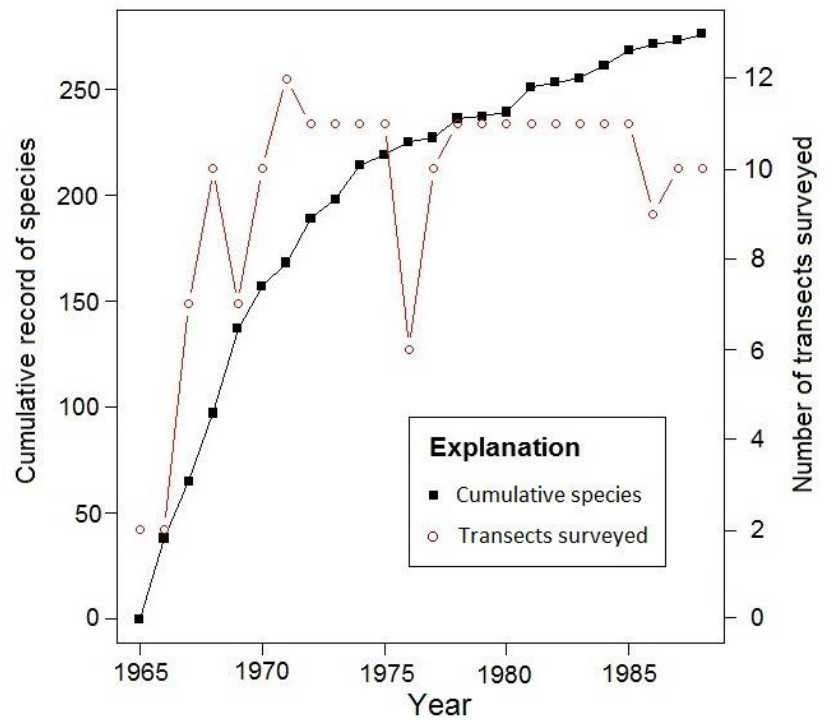

Figure 17. Cumulative number of species recorded and number of long-term transects surveyed on the Woodworth Study Area (WSA) during 1966-89. 


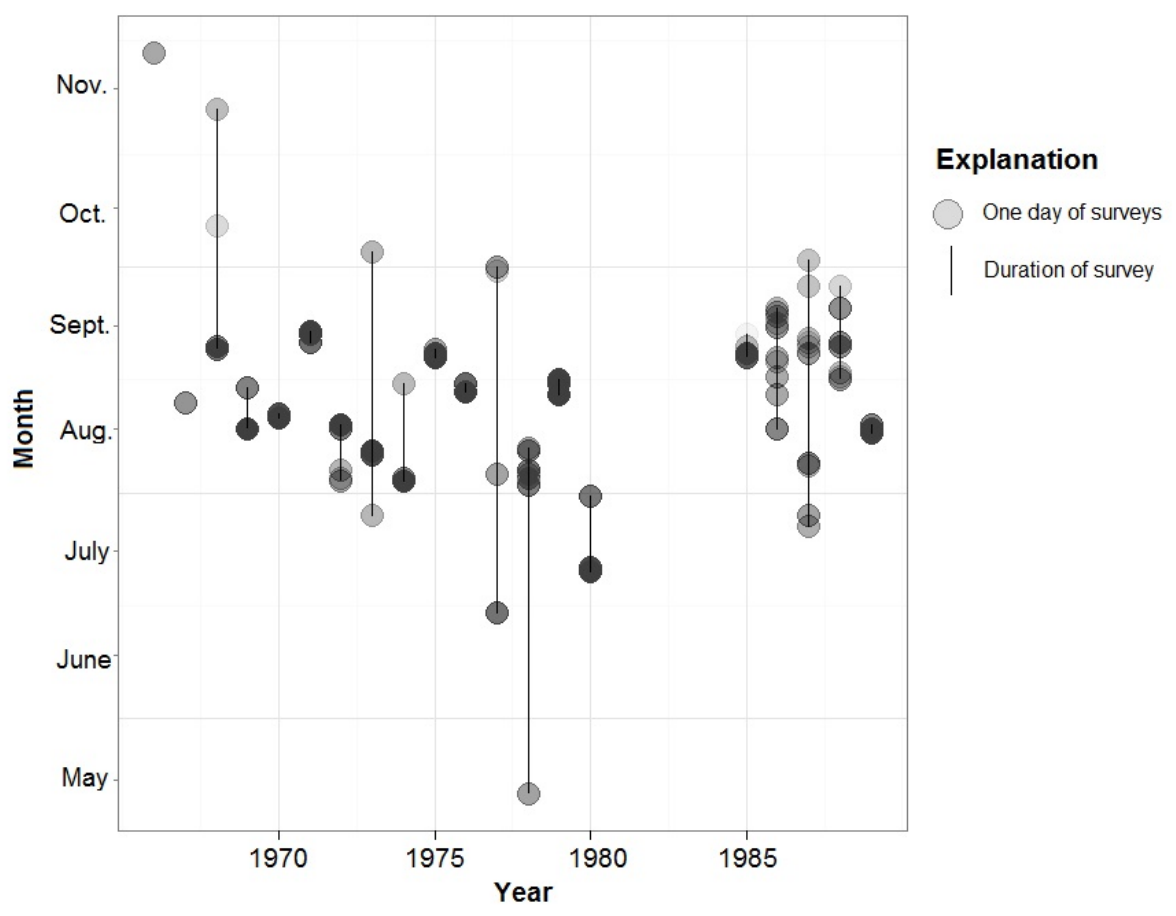

Figure 18. Survey dates for long-term transects at the Woodworth Study Area (WSA) during 1966-89. Darker shading of circles represents greater number of transects surveyed on the same day.

\section{Meyer 1980 Vegetation Transects}

A separate set of vegetation transects were established and surveyed in 1980 by Meyer (fig. 19) to provide additional quantitative results that would help interpret these data from other on-going transect surveys. The objectives of this study were to collect voucher specimens of vascular plants occurring at the WSA; describe natural plant communities; relate them to soil, aspect, and land use; and to map the mosaic of vegetation types throughout the WSA. Thus, the transects for this study were chosen to represent vegetation from several soil type, slope, and aspect combinations. Forty-two transects were established (fig. 19), and each had a number of 1 $\mathrm{m} \times 0.5 \mathrm{~m}$ stations depending on the size of the transect. There were 292 stations spaced 3-4 m apart along each 32-m transect. Each transect was marked at the beginning and end with $30-\mathrm{cm}$ tent stakes (K.H. Higgins, oral commun., 2014). Cover abundance was assessed using a modified Braun-Blanquet (1932) method similar to the long-term transects (aerial percent cover categories of $0-1,1-10,10-25,25-50,50-75,75-90$, and $90-100$ ). These transects were surveyed between July 9 and August 19, 1980. All native vegetation was classified into 5 communities and mapped (fig. 20).

Results from the survey were published (Meyer, 1985), and copies of the original field cards are available at the NPWRC. As of 1980, WSA's 587 ha of native grasslands included 432 ha of mixed grass, 87 ha of shrub, 42 ha of tall grass, 14 ha of forbs, and 3 ha of trees (fig. 20; Meyer, 1985). Additional products were generated from this study but are unpublished. Meyer surveyed all study units of the WSA on a sub-field scale and noted dominant vegetation; original data sheets are available in the NPWRC archives. Also, the plant communities of 3 select study units were mapped in detail (fig. 21). Voucher specimens of vascular plant species were collected and are stored in the herbaria at the NPWRC (appendix 11) and the WSA. 


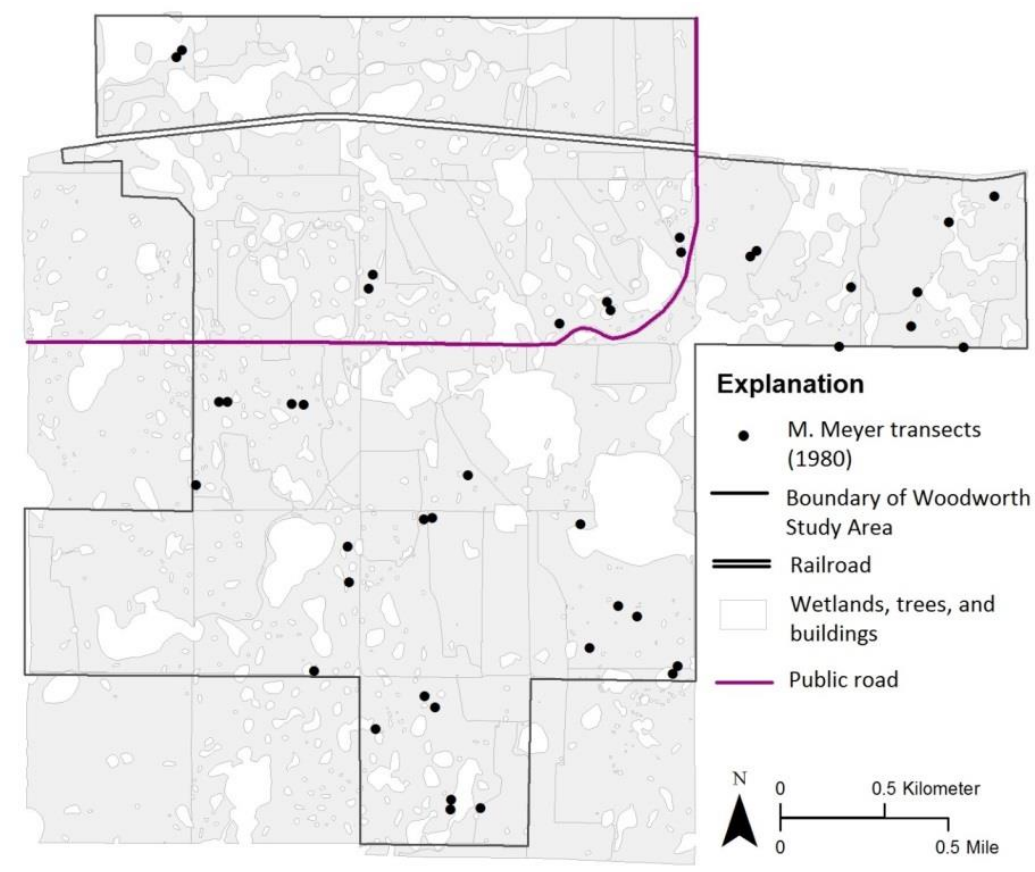

Figure 19. Approximate locations for the known vegetation transects surveyed in 1980 by Meyer (1985). The background map is delineated into functional fields that share a homogenous land-use history.

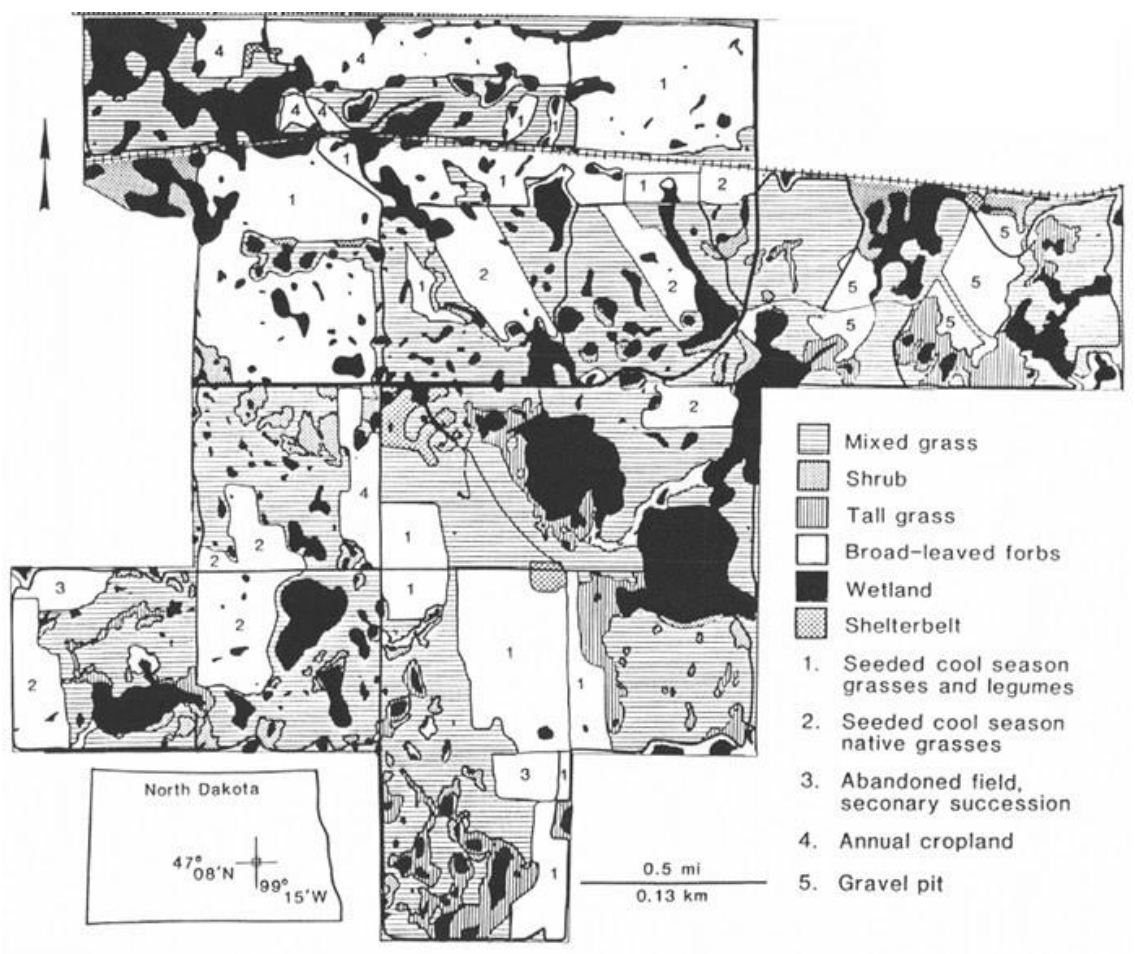

Figure 20. First thorough vegetation map at the Woodworth Study Area (WSA). From Meyer (1985: fig. 1), reprinted with permission. 

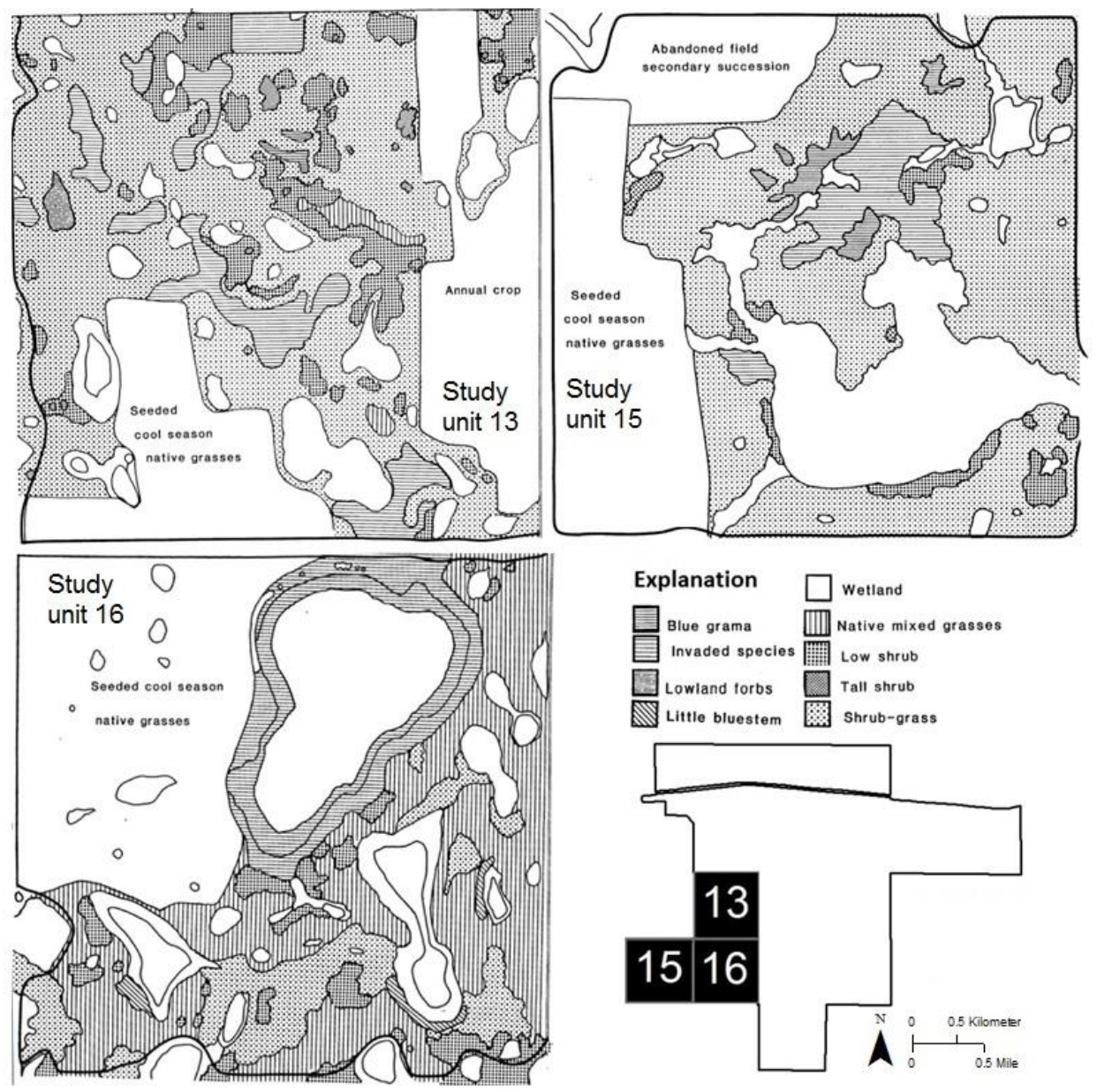

Figure 21. Detailed plant community maps of 3 study units of the Woodworth Study Area (WSA) from Meyer's 1980 surveys.

\section{Plant Phenology}

Several surveys of plant phenology have been conducted at the WSA. The most extensive was Callow and others' (1992) bloom survey, which was conducted during 1979-84. They recorded bloom stages for 97 native and introduced angiosperms at the WSA. Variables included date of first flowering or emergence, first 10 flowering individuals, full flowering aspect, flowering 95 percent complete, last flowering, and start of seed dissemination. A summary of each plant over the course of the study was published in Callow and others (1992). Paper data cards, recording each plant by year rather than summarized over the study, are kept in the NPWRC archives. The cumulative list of plants occurring at the WSA around that time identified more than 300 species, so the Callow and others' study included about one-third of all plant species recognized at the WSA at the time of the study.

Preceding Callow and others, 2 short phenology surveys were conducted at the WSA in 1975. On May 22, 1975, Stewart (written commun., 1975) recorded 32 species in bloom and 4 species with well-developed flower buds. During the course of a 6-hour survey on August 6, 1975, Stewart and Kantrud (written commun., 1975) recorded 190 species in fruit or flowering at the WSA. It is unclear what type of field or cover either survey traversed. 


\section{Vegetative Structure}

Managing grasslands for nesting waterfowl was a focus of much of the work at the WSA. By the 1930s biologists recognized the importance of vegetative cover to attract nesting ducks and protect their nests from detection by predators (for example, Grange and McAtee, 1934; Williams and Marshall, 1938). Several species, particularly mallards (Anas platyrhynchos) and northern pintails (Anas acuta), begin nesting in early April before the new vegetation growth begins (Higgins and others, 1992). Therefore, residual vegetation from the previous growing season is important to spring-nesting ducks in the PPR. Kantrud and Higgins (1992) concluded that nesting birds respond to the structure of vegetation, especially height-density and litter layer, more than the specific plant species that were present. Terrestrial bird communities of the northern Great Plains were similarly influenced by vegetation structure, height, soils, and grazing effects (Kantrud and Kologiski, 1982).

The amount of vegetative coverage, i.e., the quality of nesting cover, is a combination of the height and density of the vegetation. To measure these 2 factors, researchers at the WSA used 2 methods. From 1964 to 1975, they created and used a subjective method where in the early spring each field was assigned a cover value of 1 (poor), 2 (fair), 3 (good), or 4 (excellent). Poor sites had little nesting material and secure cover, such as in overgrazed pastures, mowed areas with little or no regrowth, or brush clumps with no understory. Fair cover provided thin uniform cover or scattered clumps of fairly dense cover in sites such as standing stubble fields, moderately grazed pastures, or brush clumps with some understory vegetation. Good cover had large expanses of nesting cover, including lightly grazed pastures and idled vegetation on poor sites that had few openings or paths. Excellent cover provided dense vegetation not interrupted by roads or trails, and offered a heavy barrier for predator movement (Kirsch and Higgins, 1976). Nesting surveys conducted at the WSA (such as Higgins and others, 1992) also routinely used this method to assign cover ratings to the area immediately around a nest. More than one-half of upland duck nests were found in cover deemed fair, and one-quarter of upland duck nests were found in good cover (Higgins and others, 1992). About an equal number were found in either poor or excellent cover. Composition of vegetation surrounding individual nests, hatching success, as well as the shape of the cover, are reported elsewhere and summarized in Higgins and others (1992).

Starting in 1974, researchers used a recently developed and more objective method for quantifying vegetative structure, the visual obstruction reading (VOR), which is informally referred to as the Robel method (Robel and others, 1970). Visual obstruction readings were made at 25 stations along each transect (fig. 22), with transects placed in various fields representing different land use histories. Mean VOR for each transect was the average of full obstruction heights for 4 cardinal directions around each station along a transect. Surveys from 1979 to 1989 also measured vegetation height by sliding a clear, plastic disc, $30 \mathrm{~cm}$ in diameter, down the pole until the first piece of vegetation touched the disc (fig. 23). Measurements of full visual obstruction and vegetation height were rounded to the nearest 0.5 decimeter (dm).

VOR data are available for 30 transects within 17 study units at the WSA. Litter height was recorded for 1974-75, and aspect or exposure of each station was recorded for 1974-77. Data from all years (1974-89, excluding 1986) are available in the original datasheets in the NPWRC archive. Subsets have been digitized (data files ROBEL6A and VISUALOB) or included in publications (Higgins, 1986b; Higgins and others, 1984; Kirsch and others, 1978), but they have not been analyzed as a whole dataset. 


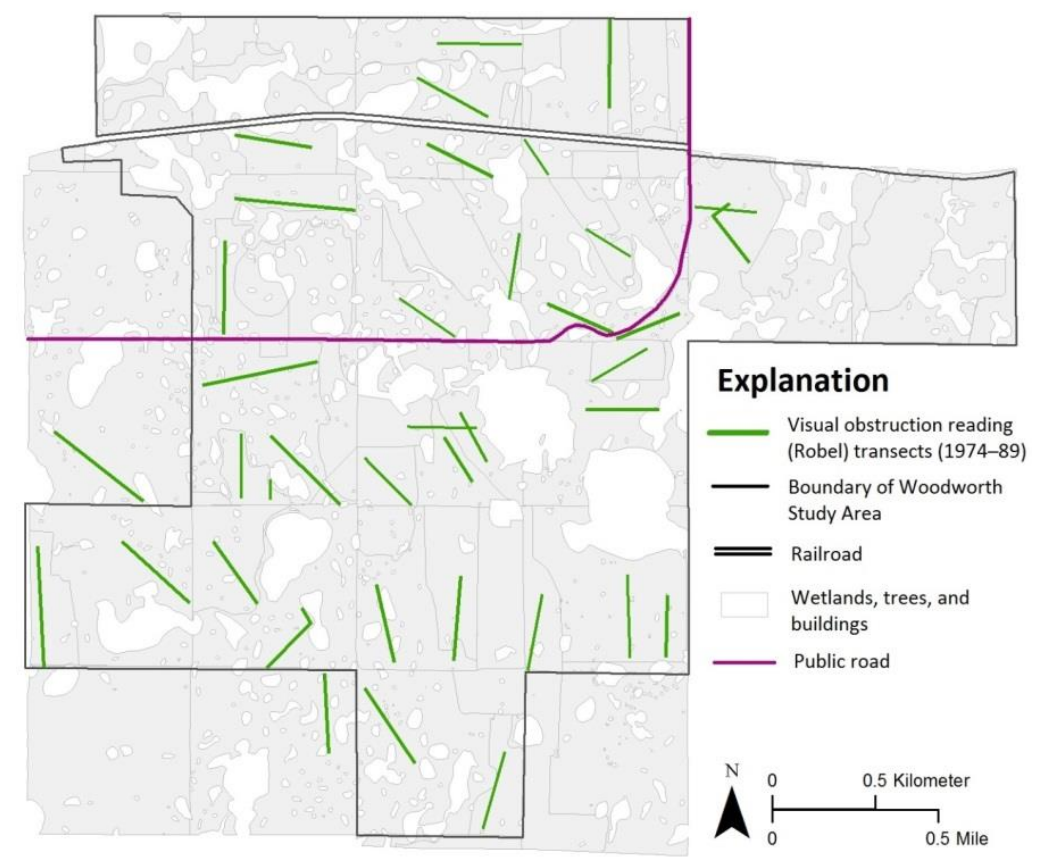

Figure 22. Transect locations for visual obstruction readings (VOR) at the Woodworth Study Area (WSA) surveyed during 1974-89. The background map is delineated into functional fields that share a homogenous land-use history.
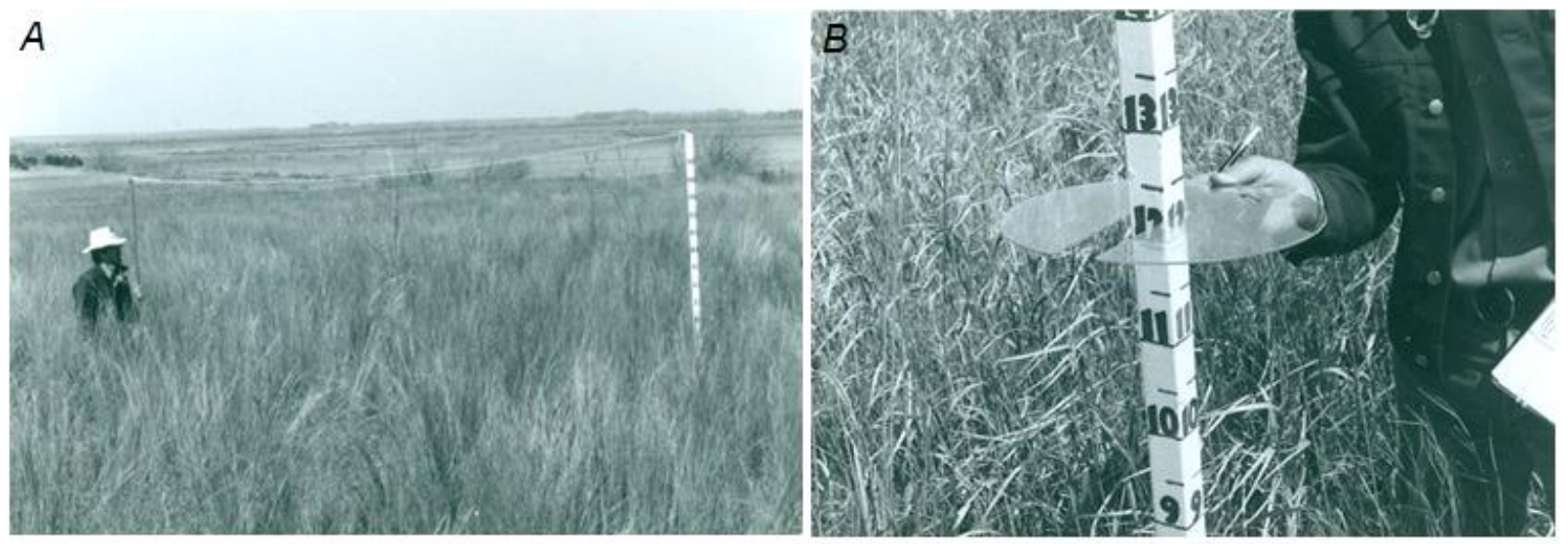

Figure 23. Measurement methods for vegetation density (visual obstruction reading [VOR]) and vegetation height using a Robel pole at the Woodworth Study Area (WSA). A, WSA staff members recorded visual obstruction of the pole from 4 meters away. $B$, Vegetation height was measured in decimeters using a clear plastic disc at the height of first contact with vegetation. Photographs taken by U.S. Fish and Wildlife Service personnel. 


\section{Wetlands and Wetland Vegetation}

The WSA contains over 300 wetland basins, thus the vegetation in and around them is a significant determinant of habitat for the study area. The pattern, density, and species composition of wetland vegetation are affected by the wetland's water depth, brackishness, and permanence. Because water chemistry tends to vary seasonally and interannually, vegetation communities integrate the fluctuations in salinity to give a more average picture of seasonal changes (Stewart and Kantrud, 1972).

Wetland vegetation surveys began soon after the study area was established and pond numbers assigned. In 1963, Bayha (written commun., 1963) identified 294 wetlands. This was expanded in 1964 to 648 wetlands and totaled 241 ha within and immediately around the study area. About 450 of these wetlands were within the federally managed bounds. All wetlands were categorized as fresh to slightly brackish ponds and classified according to an early version (Stewart and Kantrud, written commun., 1963) of the Stewart and Kantrud (1971) wetland classification system. The dominant vegetation surrounding each wetland was classified once in each decade (early 1960s, 1970s, and 1980s). Original paper data sheets are available in the NPWRC archives; it is not clear to what extent they have been used in any publications.

National Wetland Inventory data classified wetlands according to Cowardin and others (1979). Within the federally managed bounds of the WSA, 376 wetlands that represented ten classes were recognized (table 6). The 3 largest wetlands on the WSA were littoral lacustrine systems, where aquatic plants dominate and surface water is present except in extreme droughts. Almost one-half of wetlands were classed as palustrine emergent seasonally flooded but averaged only 0.2 ha in size. These wetlands are characterized by perennial vegetation that is usually present through the growing season and seasonal surface water that dries by the end of the growing season. The WSA had greater numbers of seasonal wetlands than semipermanent wetlands and relatively few temporary wetlands (fig. 24). The discrepancy between Bayha's (written commun., 1963) earlier, higher numbers of wetlands and NWI estimates has not been explored in detail, but is likely because of Bayha's inclusion of more ephemeral and temporary wetlands not detected in NWI data, and the loss of some wetlands to modifications.

Two pilot studies took place around wetlands in early years of federal management. In 1968 and 1969, WSA staff mowed the shorelines of ponds to test effects on distribution of breeding waterfowl (Klett and others, written commun., 1969). The mowed shorelines contained greater density of breeding waterfowl than the control wetlands even when the locations of the treatment and control were reversed. In the second pilot study, WSA staff installed snow fences around wetlands to test whether they could help accumulate moisture around shallow wetlands (K.F. Higgins, oral commun., 2014); no results are apparently available for this pilot study. 
Table 6. Wetland types within the federal boundaries of the Woodworth Study Area, according to National Wetland Inventory classification (NWI).

[The codes are for wetland types as defined in NWI (Cowardin and others 1979) and described in text form under Description.]

\begin{tabular}{lrrrl}
\hline NWI Code & $\begin{array}{c}\text { Number } \\
\text { of } \\
\text { wetlands }\end{array}$ & $\begin{array}{c}\text { Total } \\
\text { hectares }\end{array}$ & $\begin{array}{c}\text { Average } \\
\text { wetland } \\
\text { size } \\
\text { hectares) }\end{array}$ & Description \\
\hline PEM/ABF & 49 & 59.7 & 1.2 & Palustrine, emergent, aquatic bed, semipermanently flooded \\
L2ABG & 3 & 54.3 & 18.1 & Lacustrine, littoral, aquatic bed, intermittently exposed \\
PEMF & 66 & 52.6 & 0.8 & Palustrine, emergent, semipermanently flooded \\
PEMC & 180 & 28.3 & 0.2 & Palustrine, emergent, seasonally flooded \\
PEMA & 50 & 17.4 & 0.3 & Palustrine, emergent, temporary flooded \\
PABF & 3 & 5.3 & 1.8 & Palustrine, aquatic bed, semipermanently flooded \\
PEMCx & 12 & 1.6 & 0.1 & Palustrine, emergent, seasonally flooded, excavated \\
PEM/SSC & 1 & 1.1 & 1.1 & Palustrine, emergent, scrub-shrub, seasonally flooded \\
PEMAd & 2 & 0.6 & 0.3 & Palustrine, emergent, temporary flooded, partially \\
PABFx & 1 & 0.1 & 0.1 & Palustrine, aquatic bed, semipermanently flooded, excavated \\
Total & 367 & 221.0 & & \\
\hline
\end{tabular}

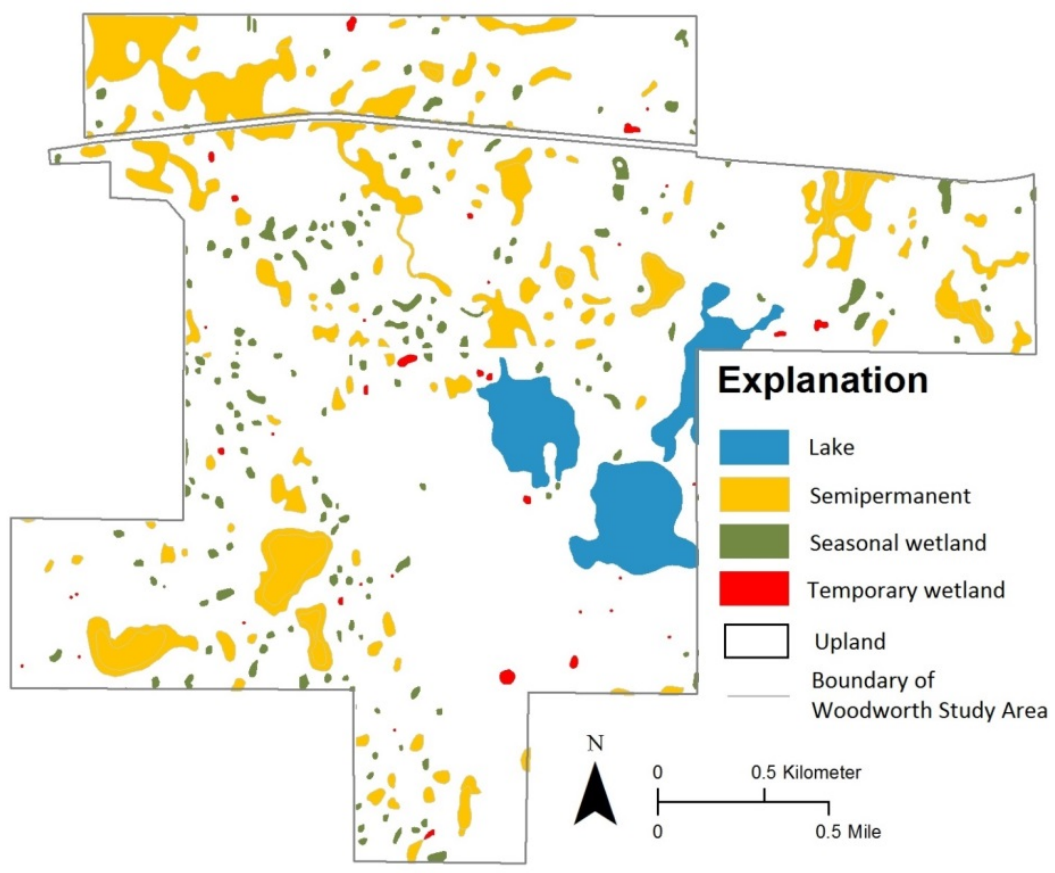

Figure 24. Wetland water regimes as identified by the National Wetland Inventory (NWI) at the Woodworth Study Area (WSA). 


\section{Preliminary Summary of the WSA Plant Community}

\section{The WSA Plant Community}

The digitized WSA vegetation datasets cumulatively consist of 450 plant species (appendix 10). The datasets included were from transect data and studies that focused mainly on upland vegetation, so although some wetland species were represented, there are likely more than 450 plant species historically found at the WSA. More than 20 years of wetland vegetation surveys are available in the NPWRC archives but are available only as original data sheets at this time. As those data are converted to digital files and examined relative to the cumulative species list, the number of wetland species recorded at the WSA may increase.

The WSA vegetation datasets include 71 taxonomic families, but 42 families were represented by only 1 or 2 species (fig. 25A). The top 5 families (Asteraceae, Poaceae, Fabaceae, Cyperaceae, and Rosaceae) contained one-half of all species at the WSA. Most species at the WSA were perennial forbs, followed by perennial grasses and annual forbs (fig. 25B). Sedges and woody species (vines, shrubs, or trees) contributed similar numbers of species, and rushes were the least numerous group (fig. 25B), which might be related to the limited number of datacollection points in wetlands. Of the forbs, 22 species were biennial (not plotted in fig. 25B). Native species outnumber non-natives in all functional categories (fig. 25C). The WSA had 348 native species and at least 69 (16.5 percent) known non-natives (fig. 25C). This is comparable to the known proportion of non-natives (15 percent) observed at the nearby CLSA during 19922001 (Mushet and others, 2004: fig. 1). The CLSA is a waterfowl production area $16 \mathrm{~km}$ southeast of the WSA that has been idled since purchased by the FWS in the early 1960s.

Nitrogen-fixing species are an important contribution to grassland productivity (LeBauer and Treseder, 2008). There were 28 plant species at the WSA able to fix nitrogen (fig. 25D). Cool-season graminoids such as crested wheatgrass (Agropyron cristatum) and smooth brome (Bromus inermis) were twice as numerous as warm-season species such as alkali cordgrass (Spartina gracilis; fig. 25D). The mean annual temperature of $5.6^{\circ} \mathrm{C}$ at the WSA falls below the $10^{\circ} \mathrm{C}$ threshold where cool-season plants occur more often than warm-season plants (Sims and Risser, 2000).

Non-native species and some invasive native species were undesirable to biologists as they were perceived to reduce habitat quality by offering little cover for wildlife or by outcompeting those plants that do benefit wildlife. In 1977, the primary "pest” plants identified in the WSA records were Kentucky bluegrass (Poa pratensis), wolfberry, and silverberry. Once established, these tended to outcompete other plants deemed more desirable for waterfowl nesting cover. Other grasses such as smooth brome and quackgrass (Elymus repens) were common non-native species on unmanaged grasslands, which also competed with native plants. However, these species were considered more acceptable than Kentucky bluegrass for wildlife management because when in vigorous growth, they provided good nesting cover. From a potential community of over 200 plants, those deemed desirable for wildlife habitat in 1977 (L. Kirsch, written commun.) included big bluestem, switchgrass, Indian grass, green needlegrass (Nassella viridula), porcupine grass (Hesperostipa spartea), blue grama (Bouteloua gracilis), prairie cordgrass (Spartina pectinata), bearded wheatgrass (Elymus caninus), prairie dropseed, (Sporobolus heterolepis), wild timothy (marsh muhly, Muhlenbergia racemosa), prairie sandreed (Calamovilfa longifolia), little bluestem (Schizachyrium scoparium), sideoats grama (Bouteloua curtipendula), western wheatgrass (Pascopyrum smithii), needle and thread (Hesperostipa comata), and native legumes. 

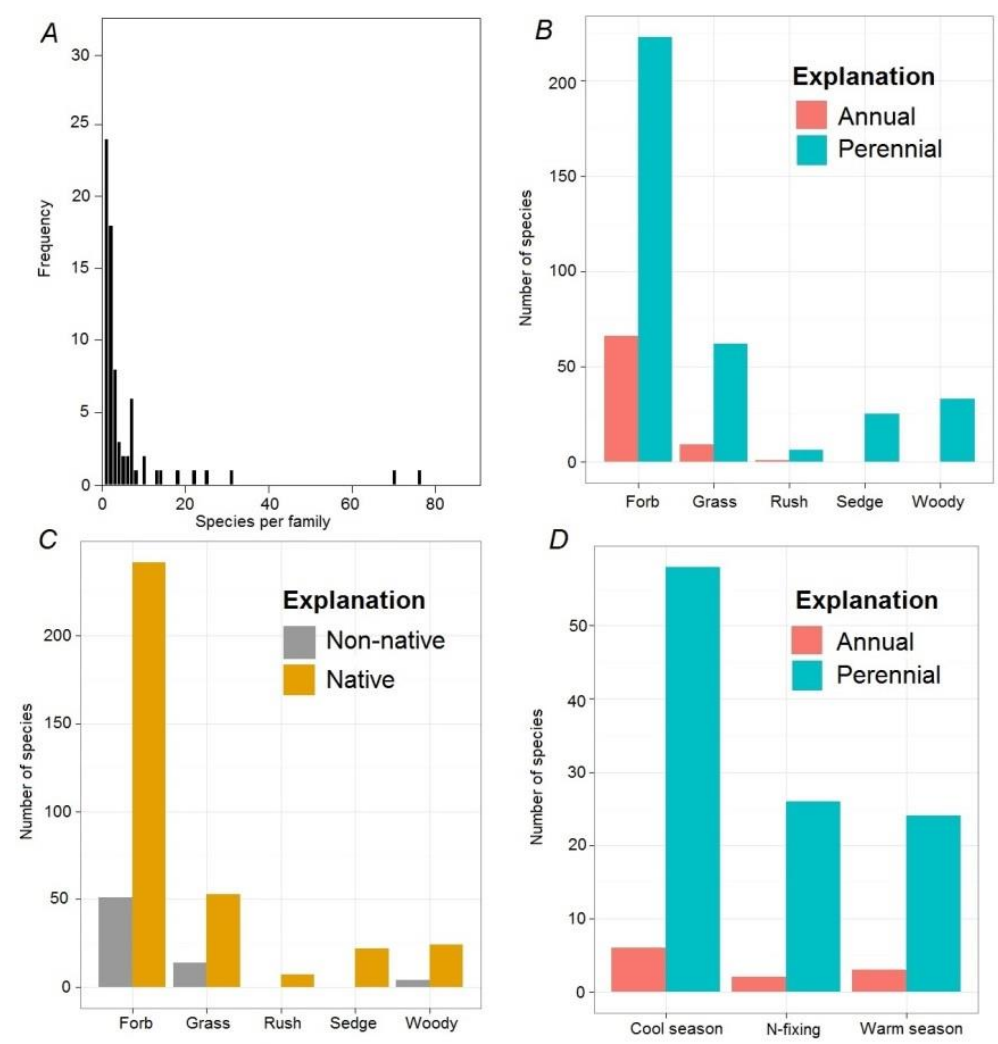

Figure 25. Summaries of plant types recorded on the Woodworth Study Area (WSA) during 1963-89. A, Histogram of the number of species per family. $B$, Plant functional groups by growth form. $C$, Numbers of native and non-native species by growth form. $D$, Numbers of annual or perennial cool-season, nitrogen $(\mathrm{N})$-fixing, and warm-season species.

\section{Floristic Quality Assessment}

Coefficients of conservatism and floristic quality assessments are tools for measuring the conservation status of a plant community. The coefficient of conservatism (C) is a number (010) assigned to each plant by a committee of experts on the region's flora (Swink and Wilhelm, 1979, 1994; Mushet and others, 2001). It is a composite score of fidelity of a species to specific environmental conditions or habitat, and tolerance to disturbance. For example, if a plant has low tolerance to disturbance and high fidelity to a region (i.e. rare or hard to find), its $C$ value would be 10. In contrast, a plant that grows in many conditions and is robust to disturbance is assigned a C near 0. Non-native species are not assigned a C value. The Floristic Quality Index (FQI) uses the $C$ values of plants in an area to provide a standardized metric to evaluate the closeness of the plant community to undisturbed conditions (Swink and Wilhelm, 1994). For any area, FQI equals the average $C$ times the square root of the number of species.

The mean C for the WSA master list of vegetation species was 5.3, and the median was 5 . The FQI was 98.6 (348 native species). Twenty-two species assigned a 10 have been observed at the WSA during 1966-89 (fig. 26). The data included in this assessment are the long-term vegetation transects, phenology records, and the most recent plant list of the WSA from 1986. To examine changes in $\mathrm{C}$ over time, we used the systematic surveys from the long-term vegetation transects, and separated the transects that had been treated by fire or grazing from transects that 
remained idle as a control. Mean $\mathrm{C}$ remained largely stable throughout the long-term data, and no clear pattern emerged across years or between idle and treated areas (fig. 27).

Similarly, the distribution of $C$ values appears largely stable across years (fig. 28). The increasing proportion of plants with $C$ values of 8-10 in the first 5 years (fig. 28) may reflect improved coverage by transects, better plant identification, or actual changes in plant occurrences. Overall, the observed occurrences of non-native species from 1966 to 1989 averaged to 4.1 percent \pm 5.5 percent (standard deviation) of species identified.

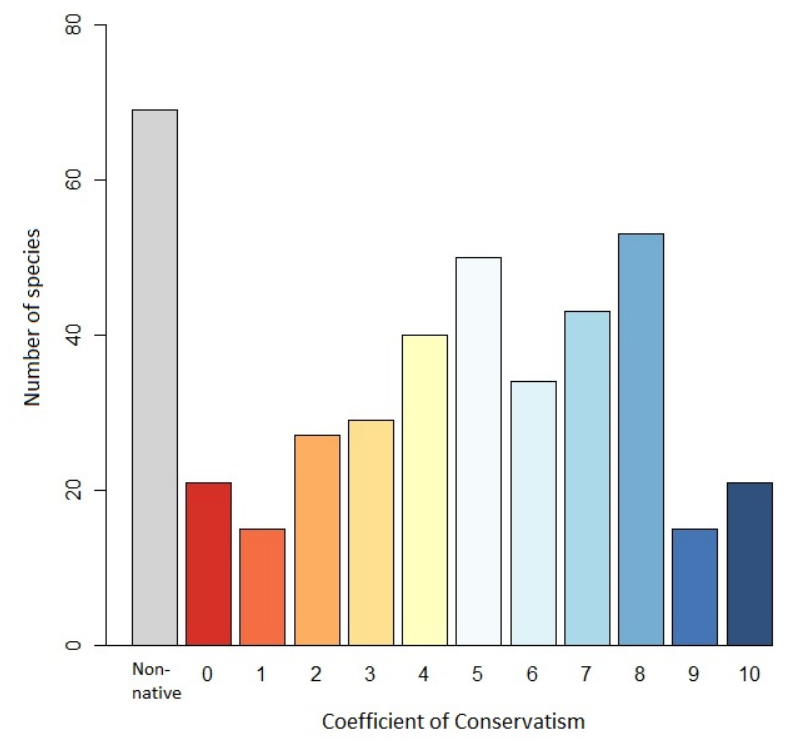

Figure 26. The frequencies of coefficients of conservatism $(C)$ scores for all taxa recorded at the Woodworth Study Area (WSA) during 1966-89. Bar colors correspond to colors in figure 28.

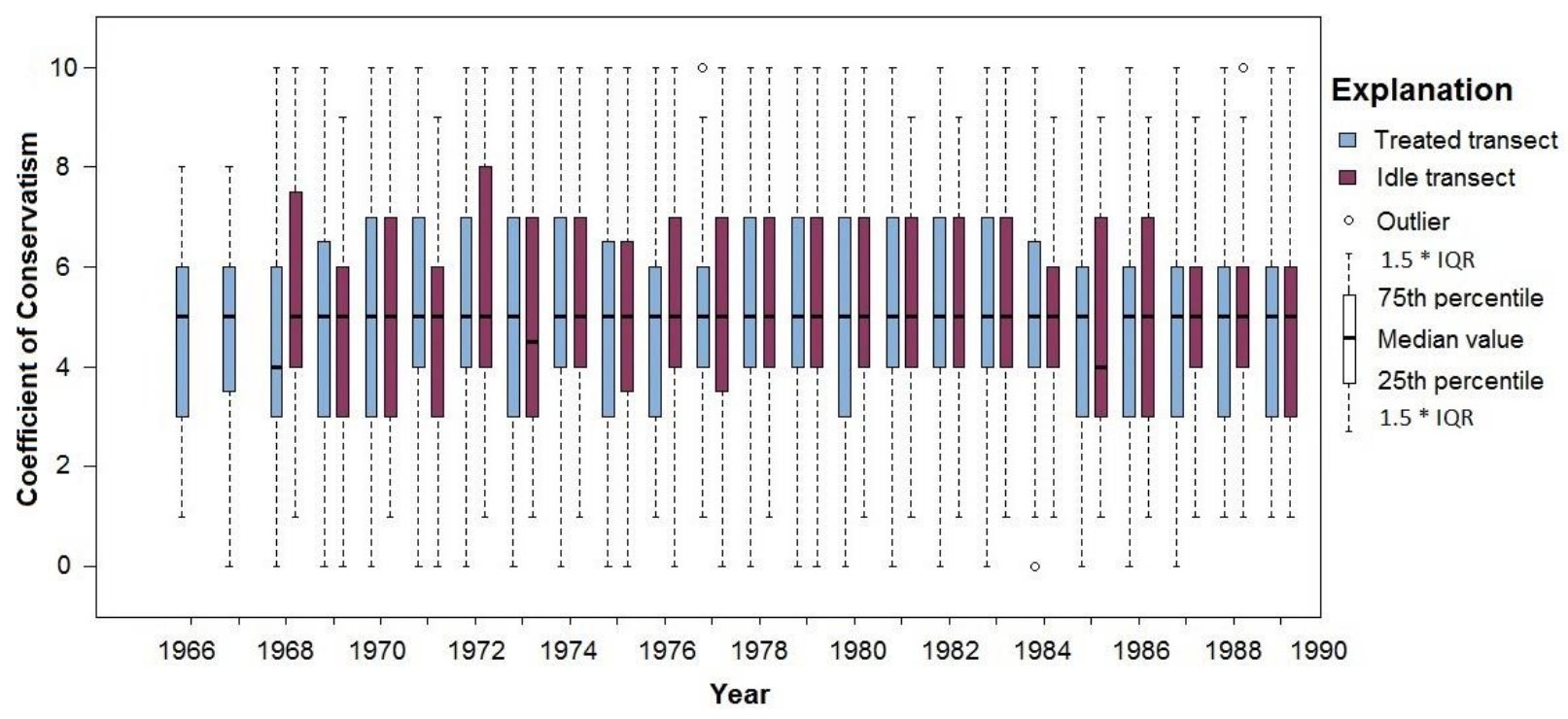

Figure 27. Boxplots of the coefficients of conservatism (C) of plants recorded on long-term transects on idle and treated fields during 1966-89. 


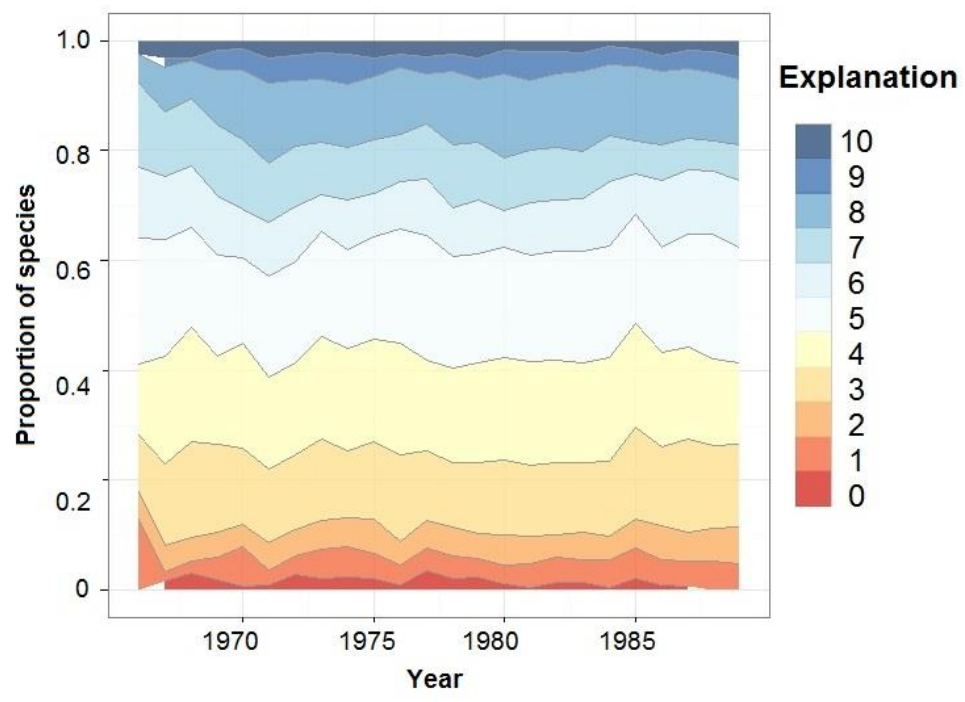

Figure 28. Proportion of native plant species recorded each year (1966-89) by coefficients of conservatism (C) on long-term transects at the Woodworth Study Area (WSA).

\section{Additional Data Resources}

\section{Wildlife Data}

In addition to the vegetative surveys discussed in this report, regular surveys included counts of duck breeding pairs and broods (Higgins and others 1992), upland waterfowl and shorebird nesting surveys, and terrestrial passerine surveys (Johnson, 1996, 1997). Surveys were conducted for varying lengths of time for other waterfowl and waterbird research (e.g., Klett and Kirsch 1976; Ryan and others, 1984). As part of state-wide surveys, sharp-tailed grouse (Tympanuchus phasianellus) surveys were conducted at the WSA and surrounding areas from 1964 to 1985 (appendix 8). Surveys of white-tailed deer (Odocoileus virginianus), ring-necked pheasants (Phasianus colchicus), small mammals, and predators were conducted occasionally, as were surveys of nests in nesting structures and on islands (Higgins and Woodward, 1996; Nelson, 1996). Early surveys of birds and small mammals were reported by Bayha (written commun., 1963). A systematic survey of small mammals was conducted in 1972 (Ladd, written comm., 1972). These data and unpublished reports are available in the NPWRC archive.

\section{Photograph Stations}

Photograph stations have been in place at the WSA since 1970. Over 30 permanent markers are placed throughout the WSA on fields with various land-use histories (native, seeded native, or seeded nesting cover) and treatments (grazed, burned, or idled). Photographs of the landscape were oriented in the same direction and taken as many as 3 times per year (fig. 29). The timing was meant to show vegetative conditions before new growth occurred in April or May, during the growing season, and near the end of the growing season in August (fig. 29; Johnson and others, 1996). All photographs have been scanned and georeferenced in a geodatabase. In recent years, photographs continue to be made at several photograph stations, so a 40 -year record is available for certain stations. No analysis or reporting has been done on this dataset. 

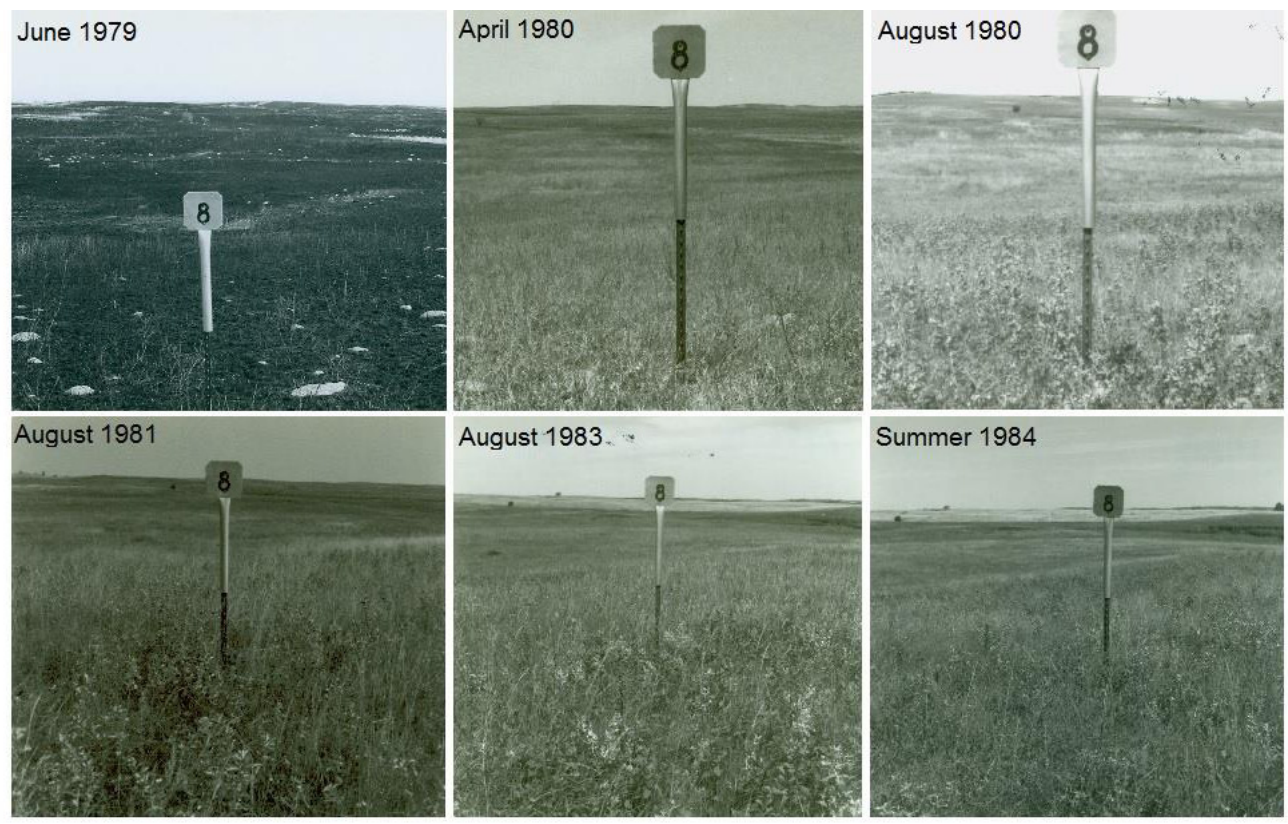

Summer 1984

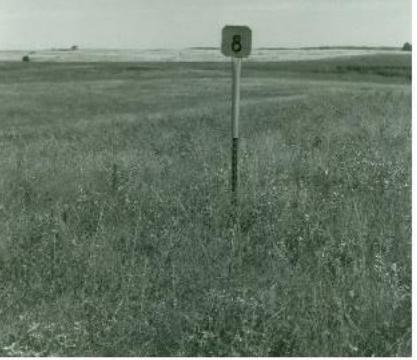

Figure 29. Example of photographs taken at a photograph station (Station 8 in study unit 16) at the Woodworth Study Area (WSA) over multiple years. Photograph taken by U.S. Fish and Wildlife Service personnel.

\section{Herbaria}

Plant species collected from the WSA are maintained in herbaria at the WSA and the NPWRC. By 1986, over 300 of the 450 identified plant species occurring on the WSA, representing 18 taxonomic families, were cataloged in the NPWRC herbaria. Appendix 11 lists the plants collected at the WSA that are archived in the NPWRC herbarium. The plants were collected by WSA staff from May 1978 to August 1981. All specimens have associated date, location, and collector metadata.

\section{Spatial Data}

During most of the WSA history, biologists relied on aerial photographs, hand-drafted maps (for example, habitat maps of Bayha, written commun., 1963; Meyer, 1985), and printed maps (for example, soils maps) to link field data to location. Geographic information systems were rapidly embraced by the NPWRC as the technology became available, and many different types of spatial data have since been captured for use in GIS applications. As part of this project, several GIS layers have been digitized from maps held in the NPWRC archive. See appendix 8 for a list of GIS data layers and appendix 12 for a list of aerial imagery. The GIS layers that were created from hardcopy maps in the NPWRC archives were produced in ESRI ArcGIS ${ }^{\circledR}$ (ESRI, 2011) and are available for download and viewing. Readers without access to ESRI ArcGIS ${ }^{\circledR}$ Desktop 10+ can download and install the free ESRI ArcReader ${ }^{\circledR} 10$ software that allows read, view, print, and identify features (ESRI, 2004). Features and layers that are currently available are categorized as locations of land treatments, features of the WSA, geophysical formations, base layers and outlines, land use and cover digitized from previous analyses, and vegetative 
transect locations. Light detection and ranging (lidar) data obtained in fall 2011 and spring 2012 are also available for the WSA at a vertical accuracy of less than or equal to $18.5 \mathrm{~cm}$ (Carswell, 2014). Aerial photographs and negatives are available for several years beginning in July 1957 (appendix 12; for example, fig. 30). WSA staff also made 2 aerial videos from 1988 and 1989 (appendix 12). All media are available in the NPWRC archives.

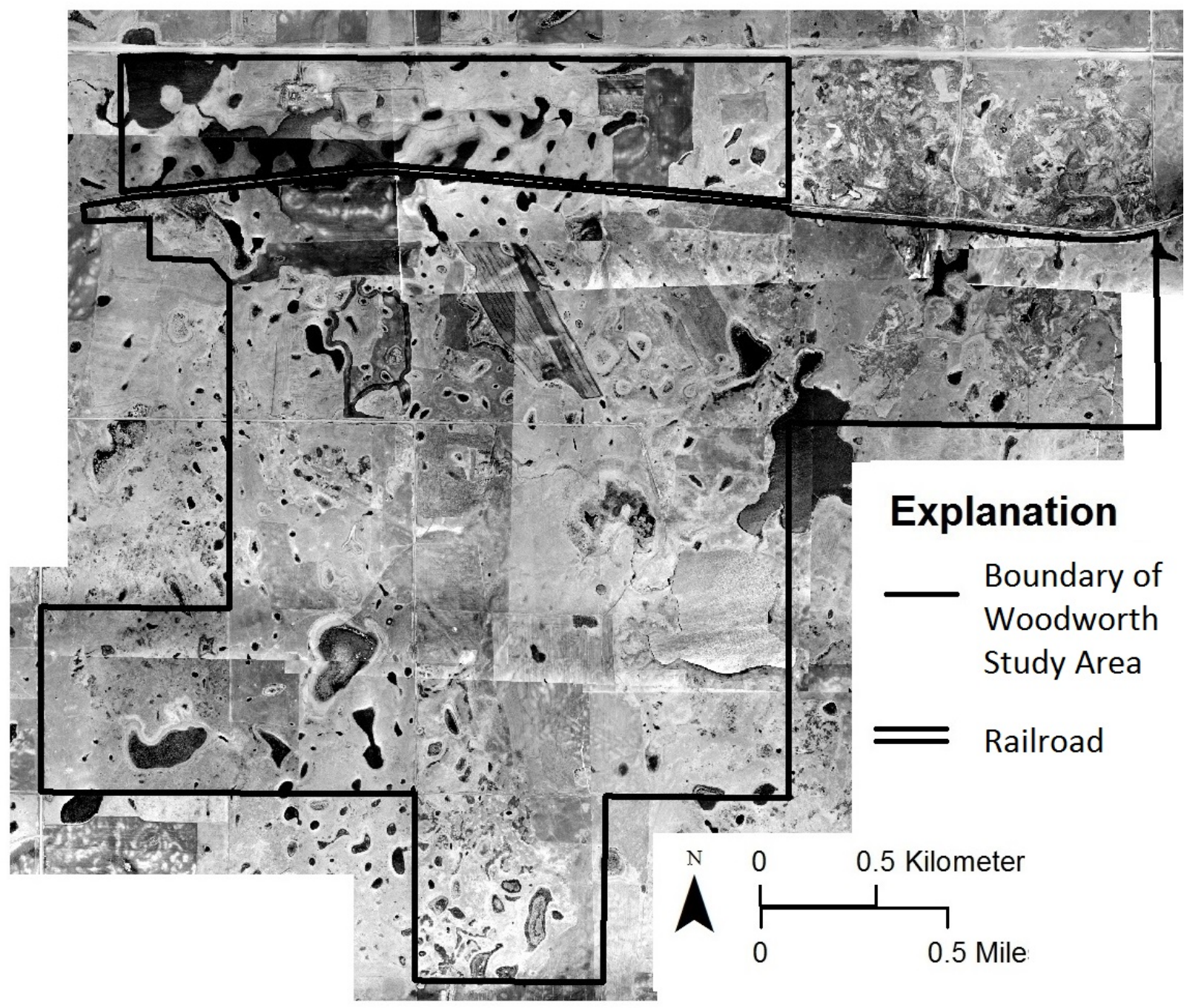

Figure 30. Composite aerial photograph of the Woodworth Study Area (WSA) taken from 9,000 feet above the surface in May, 1963. Photograph taken by U.S. Fish and Wildlife Service personnel.

\section{Data Management Strategy}

Data management for the WSA must satisfy several agencies. The CLWMD requires short- to mid-term use of the data addressing management options, whereas the NPWRC seeks a long-term data archiving solution to ensure the longevity and viability of these data for future study. Valuable data become obsolete quickly if not managed properly. The seemingly safe and well-organized compact disks used in the1990s-2000s were once the well-organized 8.5-inch 
floppy disks of the early 1980s or the magnetic tapes of the 1960s. In addition, storing data solely in proprietary formats is risky should a researcher or lab lose track of their copy of that software or find that it is no longer functional on newer computer systems.

We used a management strategy for this project to ensure the reliability and accessibility of the WSA data for 100 years or more. The so-called centinel system (Lehman and other, 2012) has 4 main tenets: (1) store a copy of the data in plain ASCII-text format, (2) store metadata in the same file as the data, (3) protect data against accidental changes or omissions; and (4) print several copies and store them in separate locations for permanent or archival data.

\section{ASCII}

Numerical data should be both human and machine readable. We find that ASCII files stored in columns and delimited by vertical bars or colons, or the like, work well. The files can be visually understood on a computer screen or paper, as well as scanned into a computer or imported to spreadsheet software. The numerical data products of the WSA vegetation project will be stored in ASCII-based datasets. These products include (1) all historical vegetation data gathered in the paper archives or already stored electronically, (2) concatenated data files, where possible, to maximize the amount and value of data, (3) a new crosswalk database to translate between original species symbols recorded at the WSA, current USDA Plant Database acronyms (appendix 10), species physiognomy, and the coefficient of conservatism codes, and (4) complete accompanying metadata. Core layers of GIS data were also converted to an ASCIIbased format (GeoJson; Butler and others, 2008) for long-term storage. This creates a digital format that can be archived on paper, and it also removed the GIS layer from a proprietary format.

The data that we have archived as part of this project are at least 20 years old, so few regular edits are expected in the future. However, in practice, editing may be necessary as more robust metadata are discovered. In this case, changes should be made primarily to the ASCII-text files stored on the network, and the changes should be noted in the accompanying metadata.

\section{Metadata}

A primary focus of this project was to provide metadata that specify data sources, formats, storage locations, and procedures for data collection and data quality. For numerical data, the Centinel system (Lehman and others, 2012) recommends storing the metadata for a file with the data. Preferably, metadata will form a header for the data that includes a description of the data that addresses the what, why, when, who, and where of the data (appendix 13). Following that should be a description of each variable including any meanings of codes or abbreviations. A complete description of abbreviations in the heading will compact the data files in the value (for example, assigning the value "native prairie" to "a", "cultivation history" to "b", etc.), and in the variable heading (for example, assigning the heading "Land use cover" to "L"). Metadata should be written to be understandable to researchers not familiar with the project. For geospatial data, standards in Executive Order 12906 (The White House, 1994) were recognized, and metadata will be prepared in compliance with the Federal Geographic Data Committee Content Standards for Digital Geospatial Metadata and Biological Resources Division Policy Issuance Number 8 (U.S. Geological Survey, 1999) following completion of the study. Data will be stored at CLWMD headquarters and at the NPWRC in compliance with FWS standards for metadata records. 


\section{Centinels}

Digital data are a precise method of recording data and can be stored electronically as well as on paper. For example, compare gathering data from a table (digital) to data from a graphical version (analog). Alphanumeric symbols can present a problem; for example, the letter $\mathrm{l}$ and the number 1 might be confused by either a reader or a scanner. To detect, prevent, and fix accidental changes or omissions, each line of data and metadata is protected by a string of characters called "centinels." The methods and code needed to use centinels are freely available in Lehman and others (2012).

\section{Paper Copies}

Given the value of the historical vegetation datasets from the WSA, at least 2 paper copies of the ASCII-based data should be made. For the WSA data covered in this report, copies have been printed, bound, and stored in both the NPWRC archive and at CLWMD headquarters. Digital copies are stored on the facilities' network drives as well. Data can be easily imported into the analysis software of the user's choice.

\section{Conclusion}

The Woodworth Study Area (WSA) has been called one of the largest controlled grassland research sites in North America (Higgins and Woodward, 1996). Research at the WSA was scaled down in the late 1980s, which unfortunately occurred just before the onset of a significant drought (1988-92) and a series of extremely wet years (1993-95). Although the 1990s and 2000s went largely unrecorded at the WSA, new attention is being given to future research there. The long record of baseline data, existing facilities at the WSA (such as the office, lab, bunkhouse, shop), and land management information that has become available in the intervening years make the future of research promising at the WSA. The WSA was selected as a core site for the National Ecological Observatory Network (NEON), a National Science Foundation-funded initiative that is committing to 30 years of ecological data collection. These WSA data, and those from the nearby Cottonwood Lake Study Area, should provide invaluable resources to help understand long-term changes in this prairie ecosystem. All the data discussed in this report are available to researchers interested in legacy vegetation data, and researchers using NEON data in particular may find the historical context helpful in their analyses. Initial data collection for NEON will begin in 2014 on study units 16 and 17 . Study unit 16 is native prairie, and study unit 17 was former cropland cultivated between the 1920s and 1969, after which it was seeded to nesting cover. Photograph stations 10, 14, and 15; visual obstruction transect 17A; long-term transects 2 and 12; and Meyer transects 1 and 27 are also nearby.

Compiling and summarizing the available WSA data may be helpful in interpreting future data in a historical context and in designing future long-term monitoring surveys, such as vegetative responses to management practices. The available data may also be valuable in addressing pressing management issues at the CLWMD, such as determining (1) reference states for the mixed-grass prairie in North Dakota (i.e. historic species composition before increases of Kentucky bluegrass, smooth brome, and the effects of decades of rest), (2) trends that identify shifts in plant species composition, (3) effects of management (such as fire, grazing, rest), and (4) effects of landscape factors that may be causing shifts in plant species composition and abundance. 
Although legacy datasets provide valuable opportunities, there are also distinct challenges for researchers. Long-term data collection may suffer from staff turnover, observational errors, chronological gaps, identification mistakes, undocumented protocol changes, or uncontrolled environmental changes. Study protocol and data at the WSA reflect the rapidly evolving nature of ecological science of the 1960s-1980s. Land management activities were not always conducted with research in mind. In addition, several datasets provide only a few years of data or breadth rather than depth of data. The WSA hosted researchers with diverse interests, creating a patchwork of projects; analyzing these smaller datasets may require supplementation with other datasets or a qualitative rather than quantitative approach. The purpose of this report was to present a summary of the individual datasets along with metadata and context without critical analysis. However, before using any of these datasets researchers should recognize both the accompanying opportunities and challenges.

\section{References Cited}

Abel, P.L., Gulsvig, A., Johnson, D.L., and Seaholm, J., 1995, Soil survey of Stutsman County, North Dakota: Washington, D.C., U.S. Department of Agriculture, Natural Resources Conservation Service, accessed July 23, 2014 at http://www.nrcs.usda.gov/Internet/FSE_MANUSCRIPTS/north_dakota/ND093/0/stutsman.pdf.

Angelo, R.T., and Anderson, K.W., 1983, The chemistry of atmospheric precipitation in North Dakota-Second annual report with comments on the ambient air quality and meteorological characteristics of North Dakota in 1982: Division of Environmental Waste Management and Research, North Dakota State Department of Health, 102 p.

Axelrod, D.I., 1985, Rise of the grassland biome, central North America: The Botanical Review, v. 51, p. 163-201.

Balée, W., 2006, The research program of historical ecology: Annual Review of Anthropology, v. 35, p. 75-98.

Batt, B.D.J., Anderson, M.G., Anderson, C.D., and Caswell, F.D., 1989, The use of prairie potholes by North American ducks, in van der Valk, A., ed., Northern Prairie Wetlands: Ames, Iowa, Iowa State University Press, p. 204-227.

Braun-Blanquet, J., 1932, Plant sociology—The study of plant communities: Hafner, N.Y., 476 p.

Butler, H., Daly, M., Doyle, A., Gillies, S., Schaub, T., and Schmidt, C., 2008, The GeoJSON format specification, revision 1.0: accessed April 21, 2014, at http://geojson.org/geojsonspec.html.

Callow, J.M., Kantrud, H.A., and Higgins, K.F., 1992, First flowering dates and flowering periods of prairie plants at Woodworth, North Dakota: Prairie Naturalist, v. 24, p. 57-64.

Carswell, W.J., Jr., 2014, The 3D Elevation Program-Summary for North Dakota: U.S. Geological Survey Fact Sheet 2014-3036, accessed April 22, 2014, at http://dx.doi.org/10.3133/fs20143036.

Clayton, L., 1966, Notes on Pleistocene stratigraphy of North Dakota: North Dakota Geological Survey Report of Investigation, v. 44, 25 p.

Cottam, C., 1958, Waterfowl research-Why research is needed: Naturalist, v. 8, p. 28-31.

Coupland, R.T., ed., 1979, Grassland ecosystems of the world-Analysis of grasslands and their uses (18th ed.): Cambridge University Press, 401 p. 
Cowardin, L.M., Carter, V., Golet, F.C., and LaRoe, E.T., 1979, Classification of wetlands and deepwater habitats of the United States: Washington, D.C., U.S. Department of the Interior, U.S. Fish and Wildlife Service FWS/OBS-79/31, 131 p.

Daubenmire, R., 1959, A canopy-coverage method of vegetational analysis: Northwest Science, v. 33, p. 43-64.

Duebbert, H.F., 1983, Seeded grasslands for wildlife habitat in the Prairie Pothole Region:

Bismarck, N. Dak., Wildlife Society of North Dakota, North Dakota Game and Fish Department, 43 p.

Duebbert, H.F., 1987, Planted grasslands for wildlife habitat in the Prairie Pothole Region, in Johnson, A.W., ed., Proceedings of the North Dakota Academy of Science: Moorhead, Minn., $41 \mathrm{p}$.

Duebbert, H.F., Jacobson, E.T., Higgins, K.F., and Podoll, E.B., 1981, Establishment of seeded grasslands for wildlife habitat in the Prairie Pothole Region: U.S. Fish and Wildlife Service, Special Scientific Report, Wildlife no. 234, 21 p.

Eisenlohr, W.S., Jr., 1972, Hydrologic investigations of prairie potholes in North Dakota, 19591968: Washington, D.C., U.S. Geological Survey Professional Paper 585-A, 102 p.

ESRI, 2004, ArcReader release 10.2: Redlands, Calif., Environmental Systems Research Institute, accessed April 21, 2014, at http://www.esri.com/software/arcgis/arcreader. 2011, ArcGIS Desktop release 10: Redlands, Calif., Environmental Systems Research Institute, accessed April 21, 2014, at http://www.esri.com/software/arcgis/arcgis-for-desktop. Euliss, N.H., Jr., LaBaugh, J.W., Fredrickson, L.H., Mushet, D.M., Laubhan, M.K., Swanson, G.A., Winter, T.C., Rosenberry, D.O., and Nelson, R.D., 2004, The wetland continuum-A conceptual framework for interpreting biological studies: Wetlands, v. 24, p. 448-458.

Fernald, M.L., 1950, Gray's Manual of botany; a handbook of the flowering plants and ferns of the central and northeastern United States and adjacent Canada: New York, N.Y., American Book Company. 1632 p.

Foster, D., Swanson, F., Aber, J., Burke, I., Brokaw, N., Tilman, D., and Knapp, A., 2003, The importance of land-use legacies to ecology and conservation: BioScience, v. 53, p. 77-88.

Gabrielson, I., 1958, Waterfowl—A problem of national significance: Naturalist, v. 8, p. 8-12.

Gleason, R.A., and Euliss, N.H., Jr., 1996, Impact of agriculture land-use on prairie wetland ecosystems-Experimental design and overview, in Garvey, R., ed., Proceedings of the North Dakota Academy of Science: Valley City, N. Dak., p. 103-107.

Grange, W.B., and McAtee, W.L., 1934, Improving the farm environment for wildlife: U.S. Department of Agriculture, Farmer's Bulletin no. 1719, 64 p.

Higgins, K.F., 1978, Fire bloopers, in Proceedings of the Prairie Prescribed Burning Symposium and Workshop: Jamestown, N. Dak., U.S. Forest Service, Bureau of Land Management, Fish and Wildlife Service, 4 p.

Higgins, K.F., 1981, “Duck stamp” dollars reserve native prairie tracts: Rangelands, v. 3, p. 190_ 191.

Higgins, K.F., 1982, Principal flora and wildlife use of a 35-40 year old gravel pit in North Dakota, in Svedarsky, W.D., and Crawford, R.D., eds., Wildlife Values of Gravel Pits Symposium Proceedings: Crookston, Minn., Northwest Agricultural Experiment Station, University of Minnesota, p. 159-161.

Higgins, K.F., 1984, Lightning fires in North Dakota grasslands and in pine-savanna lands of South Dakota and Montana: Journal of Range Management, v. 37, p. 100-103. 
Higgins, K.F., 1986a, Interpretation and compendium of historical fire accounts in the Northern Great Plains: U.S. Fish and Wildlife Service Resource Publication 161, 39 p.

Higgins, K.F., 1986b, A comparison of burn season effects on nesting birds in North Dakota mixed-grass prairie: Prairie Naturalist, v. 18, p. 219-228.

Higgins, K.F., Arnold, T.W., and Barta, R.M., 1984, Breeding bird community colonization of sown stands of native grasses in North Dakota: Prairie Naturalist, v. 16, p. 177-182.

Higgins, K.F., and Barker, W.T., 1982, Changes in vegetation structure in seeded nesting cover in the Prairie Pothole Region: U. S. Fish and Wildlife Service Special Scientific Report, Wildlife no. 242, 26 p.

Higgins, K.F., and Duebbert, H.F., 1982, Successful establishment of stands of cool-season native grasses (North Dakota): Restoration and Management Notes, v. 1, p. 12.

Higgins, K.F., Kirsch, L.M., Klett, A.T., and Miller, H.W., 1992, Waterfowl production on the Woodworth Station in south-central North Dakota, 1965-1981: U.S. Fish and Wildlife Service Resource Publication 180, 79 p.

Higgins, K.F., Kruse, A.D., and Piehl, J.L., 1989a, Prescribed burning guidelines in the Northern Great Plains: U.S. Fish and Wildlife Service, Cooperative Extension Service, South Dakota State University, U.S. Department of Agriculture EC 760, 36 p., accessed April 1, 2014, at http://www.npwrc.usgs.gov/resource/habitat/burning/index.htm.

1989b, Effects of fire in the Northern Great Plains: U.S. Fish and Wildlife Service, Cooperative Extension Service, South Dakota State University, U.S. Department of Agriculture EC 761, 48 p., accessed April 1, 2014, at http://www.npwrc.usgs.gov/resource/habitat/fire/index.htm.

Higgins, K.F, and Woodward, R.O., 1996, Waterfowl studies at the Woodworth Study Area, Stutsman County, North Dakota-1965-1995, in Garvey, R., ed., Proceedings of the North Dakota Academy of Science: Valley City, N. Dak., p. 132-134.

Higgs, E.S., 1997, What is good ecological restoration?: Conservation biology, v. 11, p. 338348.

Huang, S., Dahal, D., Young, C., Chander, G., and Liu, S., 2011, Integration of Palmer Drought Severity Index and remote sensing data to simulate wetland water surface from 1910 to 2009 in Cottonwood Lake area, North Dakota: Remote Sensing of Environment, v. 115, p. 33773389.

Huxel, C.J., Jr., and Petri, L.R., 1963, Ground water basic data, part 2: U.S. Geological Survey, County Ground Water Studies 2, Bulletin 41, accessed April 1, 2014, at http://www.swc.state.nd.us/4dlink9/4dcgi/GetContentRecord/PB-279.

Jacobson, E.T., Wark, D.B., Arnott, R.G., Haas, R.J., and Tober, D.A., 1994, Sculptured seeding-An ecological approach to revegetation: Ecological Restoration, v. 12, p. 46-50. Johnson, D.H., 1976, Effects of grassland burning on breeding birds-preliminary report, in McCullough, D., ed., Proceedings of the North Dakota Academy of Science: Moorhead, Minn., p. 24.

- 1996, Terrestrial bird communities of the Woodworth Study Area in Garvey, R., ed., Proceedings of the North Dakota Academy of Science: Valley City, N. Dak, p. 127-131. 1997. Effects of fire on bird populations in mixed-grass prairie in Knopf, F.L. and Samson, F.B., eds., Ecology and of Great Plains vertebrates, Chapter 8: New York, N.Y., Springer, p. 181-206. 
Johnson, D.H., Higgins, K.F., and Woodward, R.O., 1996, An introduction to the Woodworth Study Area, in Garvey, R., ed., Proceedings of the North Dakota Academy of Science: Valley City, N. Dak., p. 95-102.

Kantrud, H.A., 1983, An environmental overview of North Dakota—Past and present: Bismarck, N. Dak., Presentation to Department of Energy's Subcommittee on Environmental Research, Committee on Coal Gasification Research, accessed April 10, 2014, at http://www.npwrc.usgs.gov/resource/habitat/envovrvw/index.htm.

1986, Effects of vegetation manipulation on breeding waterfowl in prairie wetlands - A literature review. U.S. Fish and Wildlife Service Fish and Wildlife Technical Report no. 3, 15 p.

Kantrud, H.A., and Higgins, K.F., 1992, Nest and nest site characteristics of some groundnesting, non-passerine birds of northern grasslands: Prairie Naturalist, v. 24, p. 67-84.

Kantrud, H.A., and Kologiski, R.L., 1982, Effects of soils and grazing on breeding birds of uncultivated upland grasslands of the Northern Great Plains: U.S. Fish and Wildlife Service Wildlife Research Report no. 15, 33 p.

Kirsch, L.M., 1969, Waterfowl production in relation to grazing: The Journal of Wildlife Management, v. 33, p. 821-828.

- 1978, Effects of fire upon wildlife habitat, in Proceedings Fire and Range Management Seminar: Regina, Saskatchewan, Land Use Service DREE-PFRA, Lands Branch, Saskatchewan Department of Agriculture, p. 47-51.

Kirsch, L.M., Duebbert, H.F., and Kruse, A.D., 1978, Grazing and haying effects on habitats of upland nesting birds: Transactions of the North American Wildlife and Natural Resources Conference, v. 43, p. 486-497.

Kirsch, L.M., and Higgins, K.F., 1976, Upland sandpiper nesting and management in North Dakota: Wildlife Society Bulletin, v. 4, p. 16-20.

Kirsch, L.M., and Kruse, A.D., 1973, Prairie fires and wildlife, in Proceedings Annual Tall Timbers Fire Ecology Conference: Lubbock, Tex., p. 289-303.

Klett, A.T., and Kirsch, L.M., 1976, Diurnal use of small wetlands by ducks: Journal of Wildlife Management, v. 40, p. 351-353.

LeBauer, D.S., and Treseder, K.K., 2008, Nitrogen limitation of net primary productivity in terrestrial ecosystems is globally distributed: Ecology, v. 89, p. 371-379.

Lehman, C., Williams, S., and Keen, A., 2012, The Centinel data format-Reliably communicating through time and place in Proceedings of the International Conference on Information and Knowledge Engineering: v. 12, p. 47-53, accessed April 1, 2014, at http://world-comp.org/p2012/IKE3167.pdf.

Leopold, A., 1933, Game management: New York, Charles Scribners’ Sons.

Lorenz, R.J., and Rogler, G.A., 1971, Increasing production of native and seeded pastures with nitrogen fertilizer, in Proceedings of the 22d Annual Fertilizer Conference of the Pacific Northwest: Bozeman, Mont., p. 65-74.

Mann, G.E., 1958, Duck troubles...on the prairie: Naturalist, v. 8, p.50-52. 1974, The prairie pothole region: A zone of environmental opportunity: Naturalist vol. 21, p. 2-7.

Mason, N.A., 1938, Dakota Pioneer of Gold-Wood-Mars, 1963-1938: Woodworth, N. Dak., distributed by J. J. Dittbenner, 73 p.

Meyer, M.I., 1985, Classification of native vegetation at the Woodworth Station, North Dakota: Prairie Naturalist, v. 17, p. 167-175. 
Meyer, M.I., 1987, Planting grasslands for wildlife habitat: U.S. Fish and Wildlife Service Report, 12 p.

Meyer, M.I., 1996, Upland vegetation at the Woodworth Study Area in Garvey, R., ed., Proceedings of the North Dakota Academy of Science: Valley City, N. Dak., p. 126.

Mushet, D.M., Euliss, N.H., Jr., Lane, S.P., and Goldade, C.M., 2004, The flora of the Cottonwood Lake Study Area, Stutsman County, North Dakota: The Prairie Naturalist, v. 36, p. 43-62.

Mushet, D.M., Barker, W.T., Dekeyser, E.S., Kantrud, H.A., Kirby, D.R., Larson, G.E., Lenz, D.M., Maxwell, J.A., Melvin, N.C., III, Ode, D.J., and Pelizza, C.A., 2001, Coefficients of conservatism for the vascular flora of the Dakotas and adjacent grasslands: U.S. Geological Survey, Biological Resources Division, Information and Technology Report USGS/BRD/ITR2001-0001, 32 p.

National Oceanic and Atmospheric Administration, 2013, National Climate Data Center online divisional climate data: Silver Spring, Md., National Oceanic and Atmospheric Administration, accessed June 8, 2013, at http://www7.ncdc.noaa.gov/CDO/CDODivisionalSelect.jsp.

Nelson, H.K., 1996, Linking research with management-A historical perspective, in Garvey, R., ed., Proceedings of the North Dakota Academy of Science: Valley City, N. Dak., p. 152156.

Nelson, H.K., and Lee, F.B, 1966, A new center for waterfowl research: Naturalist, v. 17, p. 2932, accessed April 1, 2014, at http://www.npwrc.usgs.gov/about/npwrc.htm.

Neon, Inc., 2011, 2011 Science strategy - enabling continental scale ecological forecasting: Boulder, Colo., Pressmo.com, 56 p.

North Dakota State Data Center, 2000, Total population for North Dakota cities-1920 to 2000: accessed April 2, 2014, at http://www.ndsu.edu/sdc/.

Olson, D.M., Dinerstein, E., Wikramanayake, E.D., Burgess, N.D., Powell, G.V., Underwood, E.C., D'amico, J.A., Itoua, I., Strand, H.E., Morrison, J.C., Loucks, C.J., Allnutt, T.F., Ricketts, T.H., Kura, Y., Lamoreux, J.F., Wettengel, W.W., Heda, P, and Kassem, K.R., 2001, Terrestrial ecoregions of the world: A new map of life on Earth, BioScience vol. 51, p. 933938.

Olson, D.M., Dinerstein, E., Wikramanayake, E.D., Burgess, N.D., Powell, G.V.N., Underwood, E.C., D'Amico, J.A., Itoua, I., Strand, H.E., Morrison, J.C., Loucks, C.J., Allnutt, T.F., Ricketts, T.H., Kura, Y., Lamoreux, J.F., Wettengel, W.W., Hedao, P., and Kassem, K.R., 2001, Terrestrial Ecoregions of the World: A New Map of Life on Earth: BioScience, v. 51, p. 933-938.

Omodt, H.W., Johnsgard, G.A., Patterson, D.D., and Olson, O.P., 1968, The major soils of North Dakota: North Dakota Agricultural Experiment Station Bulletin 472, 60 p.

Patterson, D.D., Johnsgard, G.A., Sweeney, M.D., and Omodt, H.W., 1968, Soil Survey Report, County General Soil Maps, North Dakota: North Dakota Agricultural Experiment Station Bulletin 473, 150 p.

Robel, R.J., Briggs, J.N., Dayton, A.D., and Hulbert, L.C., 1970, Relationships between visual obstruction measurements and weight of grassland vegetation: Journal of Range Management, v. 23, p 295-297.

Ryan, M.R, Renken, R.B., and. Dinsmore, J.J., 1984, Marbled godwit habitat selection in the northern prairie region. Journal of Wildlife Management, vol. 48, p. 1206-1218. 
Sims, P.L., and Risser, P.G., 2000, Grasslands, in Barbour, M.G., and Billings, W.D., eds., North American terrestrial vegetation (2d ed.): Cambridge University Press, p. 323-356.

Sloan, C.E., 1972, Ground-water hydrology of prairie potholes in North Dakota: Washington, D.C., U.S. Geological Survey Professional Paper 585-C, 28 p.

Stewart, R.E., and Kantrud, H. A., 1971, Classification of natural ponds and lakes in the glaciated prairie region: Washington, D.C., U.S. Fish and Wildlife Service, Resource Publication 92, 57 p. 1972, Vegetation of prairie potholes, North Dakota, in relation to quality of water and other environmental factors: Washington, D.C., U.S. Geological Survey Professional Paper 585-D, 36 p.

Swanson, G.A., Winter, T.C., Adomaitis, V.A., and LaBaugh, J.W., 1988, Chemical characteristics of prairie lakes in south-central North Dakota-Their potential for influencing use by fish and wildlife: Washington, D.C., U.S. Fish and Wildlife Service Technical Report 18, 44 p.

Swink, F., and Wilhelm, G.S., 1979, Plants of the Chicago region (3d ed.): Lisle, Ill., Morton Arboretum, 932 p.

1994, Plants of the Chicago region (4th ed.): Indianapolis, Ind., Indiana Academy of Science, $921 \mathrm{p}$.

The White House, 1994, Executive Order 12906, Coordinating Geographic Data Acquisition and Access: The National Spatial Data Infrastructure, 59 Fed. Reg. 17671-74 (Apr. 11, 1994).

Tutill, S.J., Clayton, L., and Laird, W.M., 1964, A comparison of a fossil Pleistocene molluscan fauna from North Dakota with a recent molluscan fauna from Minnesota: American Midland Naturalist, v. 71, p. 344-362.

U.S. Department of Agriculture, 2009, Soil Survey Geographic Database (SSURGO): Lincoln, Nebr., U.S. Department of Agriculture, Natural Resources Conservation Service, National Soil Survey Center, accessed March 1, 2014, at http://websoilsurvey.nrcs.usda.gov/.

— 2013, 2012 acreage data as of January 2013: Washington, D.C., U.S. Department of Agriculture, Farm Service Agency, accessed April 1, 2014, at http://www.fsa.usda.gov/FSA/webapp?area=newsroom\&subject=landing\&topic $=$ foi-er-fricad.

— 2014, The PLANTS database: Greensboro, N. C., U.S. Department of Agriculture, Natural Resources Conservation Service, National Plant Data Team, accessed April 3, 2014, at http://plants.usda.gov.

U.S. Geological Survey, 1999, Metadata for data sets and information products: Reston, Virg., U.S. Geological Survey, Biological Resources Division, Policy Issuance no. 08, 2 p.

Williams, C.S., and Marshall, W.H., 1938, Duck nesting studies, Bear River Migratory Bird Refuge, Utah, 1937: Journal of Wildlife Management, v. 2, p. 29-48.

Winter, T.C., and Rosenberry, D.O., 1995, The interaction of ground water with prairie pothole wetlands in the Cottonwood Lake area, east-central North Dakota, 1979-1990: Wetlands, v. 15, p. 193-211.

Winters, H.A., 1963, Geology and ground water resources of Stutsman County, North Dakota, Bulletin 41: Grand Forks, N. Dak., North Dakota Geological Survey County Ground Water Studies 2, accessed April 1, 2014, at http://www.swc.state.nd.us/4dlink9/4dcgi/GetContentRecord/PB-279.

Woodworth Betterment Community, 1986, The Woodworth Rustler, Woodworth, Stutsman County, North Dakota, June 20-21, 1986: Two Rivers Printing, 388 p. 


\section{Appendices}




\section{Appendix 1. Unpublished reports relating to the Woodworth Study Area (WSA) archived at Northern Prairie Wildlife Research Center}

Bayha, K.D., 1963, Preliminary waterfowl and habitat surveys on the Woodworth substation, Northern Prairie Wildlife Research Center, during 1963: Jamestown, N. Dak., U.S. Fish and Wildlife Service, Northern Prairie Wildlife Research Center, unpublished report, 64 p. 1964a, History of the Woodworth Study Area with emphasis on land use: Jamestown, N. Dak., U.S. Fish and Wildlife Service, Northern Prairie Wildlife Research Center, unpublished report, $76 \mathrm{p}$.

1964b, Inventory of wildlife populations and habitat conditions on the Woodworth Study Area, 1963-1964: Jamestown, N. Dak., U.S. Fish and Wildlife Service, Northern Prairie Wildlife Research Center, unpublished report, 81 p.

Johnson, D.H., 1982, Relations of selected prairie plants with environmental attributes on the Woodworth Study Area, North Dakota: Jamestown, N. Dak., U.S. Fish and Wildlife Service, Northern Prairie Wildlife Research Center internal files, 30 p.

Klett, A.T., Kirsch, L.M., Higgins, K.F., King, R., Dwyer, T., and Murdy, H.W., 1969, Effect of land-use on waterfowl and other wildlife populations, zone of influence of land-use on waterfowl populations, Annual Progress Report 1968-1969: Jamestown, N. Dak., Northern Prairie Wildlife Research Center, unpublished report, 30 p.

Ladd, W.N., 1972, Relationships of small mammals to land use treatments, Woodworth Study Area, North Dakota, 1972: Jamestown, N. Dak., Northern Prairie Wildlife Research Center, unpublished report, $39 \mathrm{p}$.

Stewart, R.E., and Kantrud, H.A., 1963, Long-term investigations of pothole complexes on the Missouri Coteau in Stutsman County, North Dakota, Annual Progress Report, Wildlife Research Work Unit A-7.1: Denver, Colo., U.S. Fish and Wildlife Service, Denver Wildlife Research Center, unpublished report, 62 p. 


\section{Appendix 2. Published and unpublished reports that use vegetation or weather data from the Woodworth Study Area (WSA) region}

Arnold, T.W., and Higgins, K.F., 1986, Effects of shrub coverages on birds of North Dakota mixed-grass prairies: Canadian Field-Naturalist, v. 100, p. 10-14.

Bayha, K.D., 1963, Preliminary waterfowl and habitat surveys on the Woodworth substation, Northern Prairie Wildlife Research Center, during 1963: Jamestown, N. Dak., U.S. Fish and Wildlife Service, Northern Prairie Wildlife Research Center, unpublished report, 64 p.

Callow, J.M., Kantrud, H.A., and Higgins, K.F., 1992, First flowering dates and flowering periods of prairie plants at Woodworth, North Dakota: Prairie Naturalist, v. 24, p. 57-64.

Hammond, M.C., and Johnson, D.H., 1984, Effects of weather on breeding ducks in North Dakota: Washington, D.C., U.S. Fish and Wildlife Technical Report FWS-TR-1, 17 p.

Higgins, K.F., 1986, A comparison of burn season effects on nesting birds in North Dakota mixed-grass prairie: Prairie Naturalist, v. 18, p. 219-228.

Higgins, K.F., and Barker, W.T., 1982, Changes in vegetation structure in seeded nesting cover in the Prairie Pothole Region: Washington, D.C., U.S. Fish and Wildlife Service Special Scientific Report Wildlife no. 242, 27 p.

Higgins, K.F., Arnold, T.W., and Barta, R.M., 1984, Breeding bird community colonization of sown stands of native grasses in North Dakota: Prairie Naturalist, v. 16 p. 177-182.

Higgins, K.F., Kirsch, L.M., Klett, A.T., and Miller, H.W., 1992, Waterfowl production on the Woodworth Station in south-central North Dakota, 1965-1981: U.S. Fish and Wildlife Service Resource Publication no. 180, 79 p.

Higgins, K.F., 1982, Principal flora and wildlife use of a 35-40 year old gravel pit in North Dakota, in Svedarsky, W.D. and Crawford, R.D., eds., Wildlife Values of Gravel Pits Symposium Proceedings: Crookston, Minn., Northwest Agricultural Experiment Station, University of Minnesota, p. 159-161.

Johnson, D.H., 1982, Relations of selected prairie plants with environmental attributes on the Woodworth Study Area, North Dakota: Jamestown, N. Dak, U.S. Fish and Wildlife Service, Northern Prairie Wildlife Research Center internal files, $30 \mathrm{p}$.

Kirsch, L.M., Duebbert, H.F., and Kruse, A.D., 1978, Grazing and haying effects on habitats of upland nesting birds: Transactions of the North American Wildlife and Natural Resources Conference, v. 43, p. 486-497.

Ladd, W.N., 1972, Relationships of small mammals to land use treatments, Woodworth Study Area, North Dakota, 1972: Jamestown, N. Dak., U.S. Fish and Wildlife Service, Northern Prairie Wildlife Research Center, unpublished report, 39 p.

Meyer, M.I., 1985, Classification of native vegetation at the Woodworth Station, North Dakota: Prairie Naturalist, v. 17, p. 167-175.

Renken, R.B., and Dinsmore, J.J., 1987, Nongame bird communities on managed grasslands in North Dakota: Canadian Field Naturalist, v. 101, p. 551-557. 


\section{Appendix 3. Woodworth Study Area (WSA) tract locations and ownership}

[Study unit follows WSA convention. Year acquired is when the tract came under federal management; NA indicates the tract remained in private ownership. Tract name is the reference name used on land management records. The final three columns are number of wetlands on the tracts in 1970, the tract size in both hectares (ha) and acres (ac), and township plat location. T. = Township, R. = Range, sec. = section, and R.R = railroad. Tracts with no wetland data are indicated by nd.]

\begin{tabular}{|c|c|c|c|c|c|}
\hline $\begin{array}{l}\text { Study } \\
\text { unit }\end{array}$ & $\begin{array}{c}\text { Year } \\
\text { acquired }\end{array}$ & Tract name & $\begin{array}{l}\text { Number of } \\
\text { wetlands } \\
\text { in } 1970\end{array}$ & $\begin{array}{l}\text { Tract size in } \\
\text { ha (ac) }\end{array}$ & Plat location \\
\hline 1 & 1968 & Rickford & 21 & $64.7(160)$ & NE1/4 sec. 1 , T. 142 N., R. 68 W. \\
\hline 2 & 1968 & Rickford & 35 & $64.7(160)$ & NW11/4 sec. 1 , T. 142 N., R. 68 W. \\
\hline 3 & 1968 & Rickford & 18 & $64.7(160)$ & NE1/4 sec. 2, T. 142 N., R. 68 W. \\
\hline 4 & 1968 & Rickford & 9 & $26.4(65.1)$ & E1/2NW1/4 north of R.R. sec. 2, T. 142 N., R. 68 W. \\
\hline 4 & 1975 & Hotchkiss & nd & $12.6(31.1)$ & NW11/4 south of R.R. sec. 2, T. 142 N., R. 68 W. \\
\hline 5 & NA & Hotchkiss & nd & $59.47(147)$ & SW11/4 sec. 2, T. 142 N., R. 68 W. \\
\hline 6 & 1967 & Bohl & 39 & $64.7(160)$ & SE $1 / 4$ sec. 1, T. 142 N., R. 68 W. \\
\hline 7 & 1969 & Kutz & 35 & $64.7(160)$ & SW11/4 sec. 1 , T. 142 N., R. 68 W. \\
\hline 8 & 1963 & Eddy & 34 & $64.7(160)$ & SE $1 / 4$ sec. 1 , T. 142 N., R. 68 W. \\
\hline 9 & 1966 & Railroad & 11 & 70 (173) & SW11/4 sec. 6, T. 142 N., R. 67 W.; NW11/4 south of R.R. \\
\hline $9 \mathrm{~A}$ & 1966 & Railroad & nd & $65.5(161.8)$ & W. $435 \mathrm{ft}$ of SE1/4 sec. 6, T. 142 N., R. 67 W.; NE $1 / 4$ south of R.R. \\
\hline 10 & NA & Holzworth & nd & $64.7(160)$ & NW11/4 sec. 7, T. 142 N., R. 67 W. \\
\hline 11 & 1962 & Fish & 22 & $64.7(160)$ & NE1/4 sec. 12, T. 142 N., R. 68 W. \\
\hline 12 & 1963 & Eddy & 19 & $64.7(160)$ & NW¹/4 sec. 12, T. 142 N., R. 68 W. \\
\hline 13 & 1963 & Eddy & 47 & $64.7(160)$ & NE1/4 sec. 11, T. 142 N., R. 68 W. \\
\hline 14 & NA & Hotchkiss & 36 & $64.7(160)$ & NW¹/4 sec. 11, T. 142 N., R. 68 W. \\
\hline 15 & 1963 & Eddy & 24 & $64.7(160)$ & SW11/4 sec. 11, T. 142 N., R. 68 W. \\
\hline 16 & 1963 & Eddy & 32 & $64.7(160)$ & SE1/4 sec. 11 , T. 142 N., R. 68 W. \\
\hline 17 & 1962 & Fish & 28 & $64.7(160)$ & SW11/4 sec. 12, T. 142 N., R. 68 W. \\
\hline
\end{tabular}




\begin{tabular}{|c|c|c|c|c|c|}
\hline $\begin{array}{l}\text { Study } \\
\text { unit }\end{array}$ & $\begin{array}{c}\text { Year } \\
\text { acquired }\end{array}$ & Tract name & $\begin{array}{c}\text { Number of } \\
\text { wetlands } \\
\text { in } 1970 \\
\end{array}$ & $\begin{array}{l}\text { Tract size in } \\
\text { ha (ac) }\end{array}$ & Plat location \\
\hline 18 & 1962 & Fish & 23 & $64.7(160)$ & SE1/4 sec. 12, T. 142 N., R. 68 W. \\
\hline 19 & NA & Holzworth & nd & $64.7(160)$ & SW1⁄4 sec. 7, T. 142 N., R. 68 W. \\
\hline 20 & NA & Holzworth & nd & $34.2(84.5)$ & E1/2NW11/4 sec. 18, T. 142 N., R. 67 W. \\
\hline 20 & NA & Stoppleworth & nd & $29.4(72.6)$ & W11/2NW11/4 sec. 18, T. 142 N., R.67W. \\
\hline 21 & NA & Stoppleworth & nd & $64.7(160)$ & NE1/4 sec. 13, T. 142 N., R. 68 W. \\
\hline 22 & 1962 & Fish & 39 & $64.7(160)$ & NW1/4 sec. 13, T. 142 N., R. 68 W. \\
\hline 23 & NA & Krenz & 49 & $64.7(160)$ & NE1/4 sec. 14, T. 142 N., R. 68 W. \\
\hline 24 & NA & Krenz & nd & $64.7(160)$ & NW1/4 sec. 14, T. 142 N., R. 68 W. \\
\hline
\end{tabular}


Appendix 4. Soil classifications at the Woodworth Study Area (WSA) using the Soil Survey Geographic Database (SSURGO)

Data source is the U.S. Department of Agriculture (2009). Scale is consistent across the 3 maps.
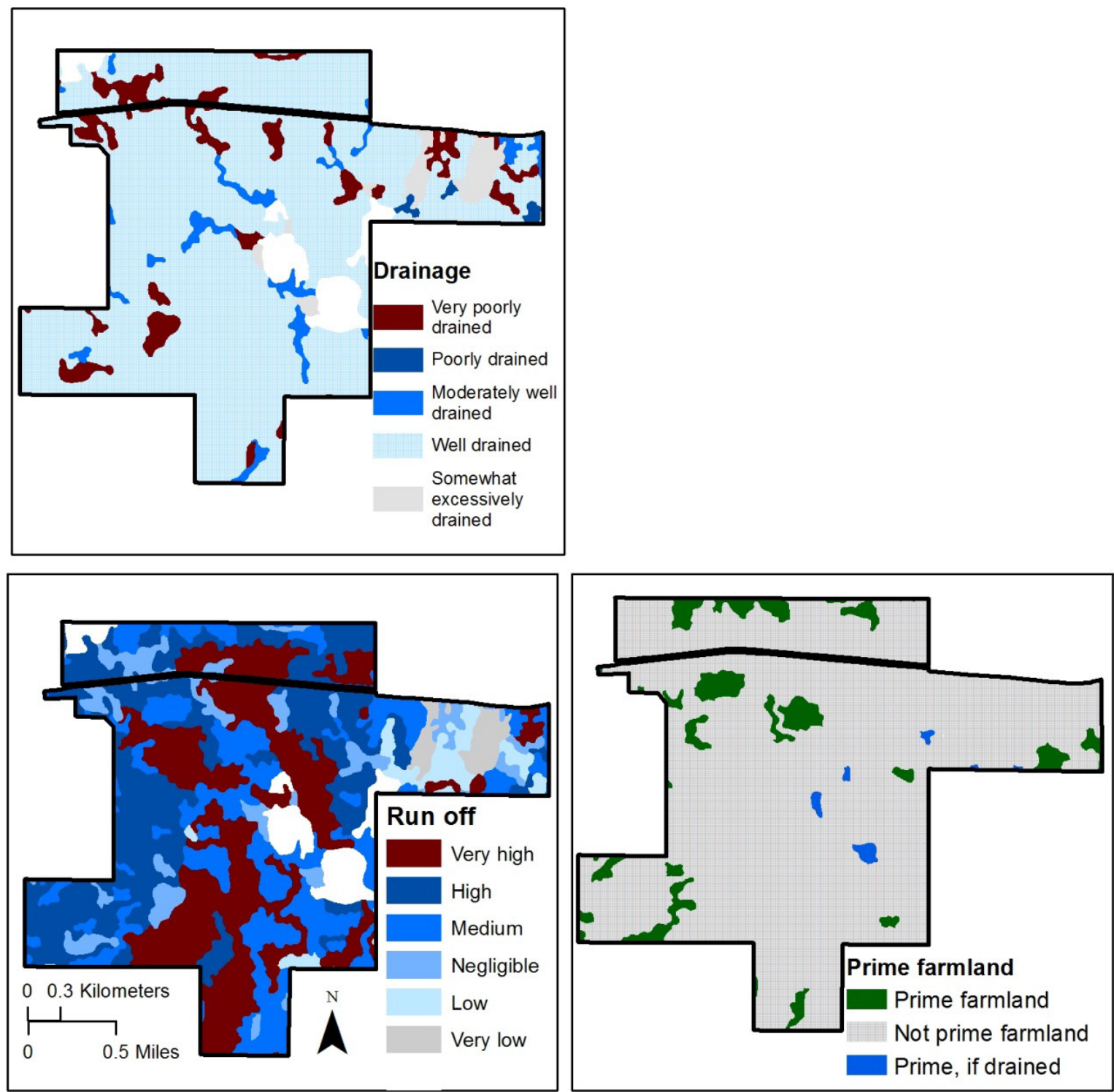


\section{Appendix 5. Original survey map of townships encompassing the Woodworth Study Area (WSA) from 1875}

The original township survey from 1875 shows several of the Woodworth Study Area's larger wetlands that lie on the section survey lines. Big Lake is the large wetland mapped along the A line. Plat maps and notes are available online at $h t t p: / / s u r v e y . s w c . n d . g o v /$. Accessed 14 April, 2014.

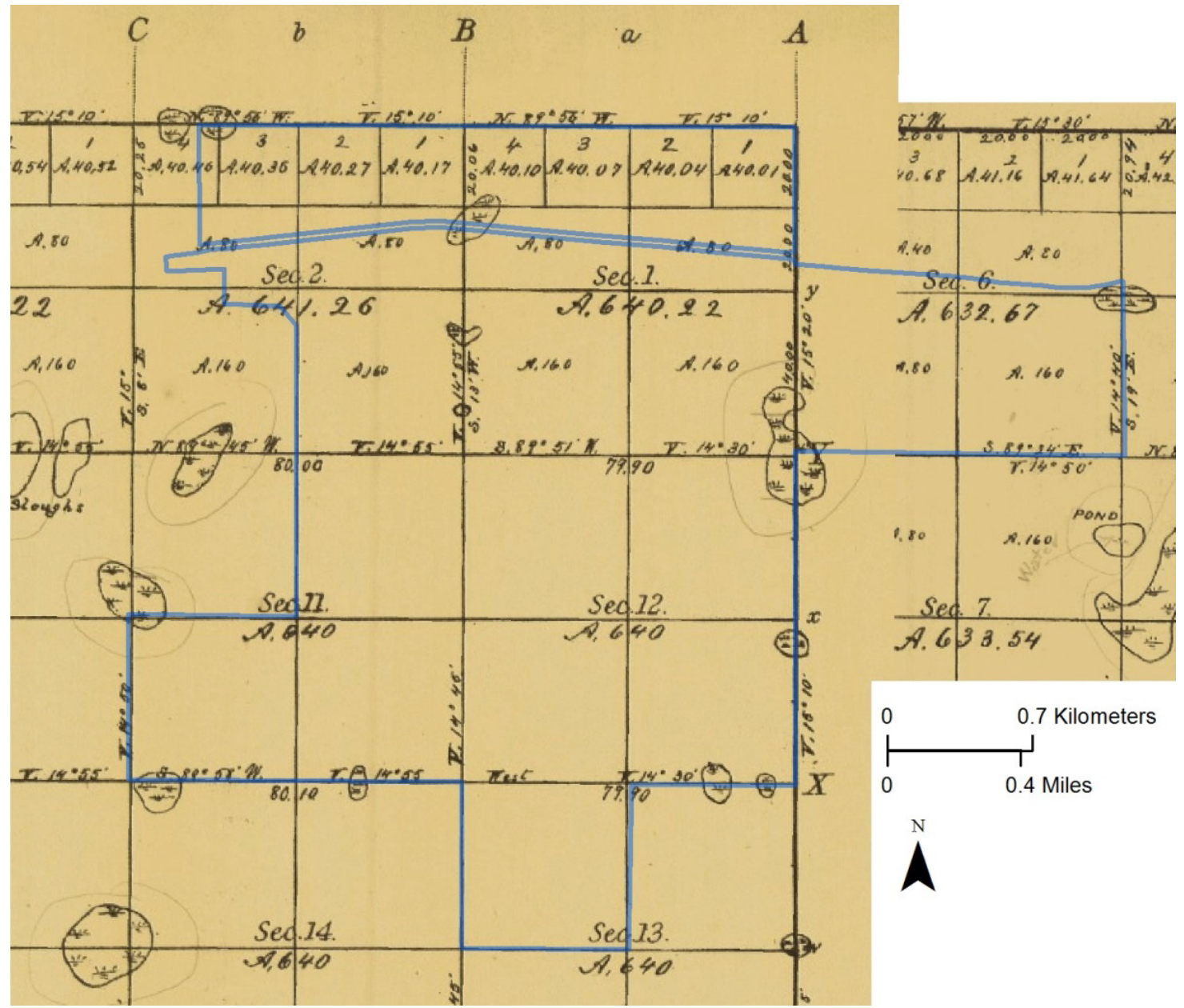


Appendix 6. Locations of man-made structures at the Woodworth Study Area (WSA)

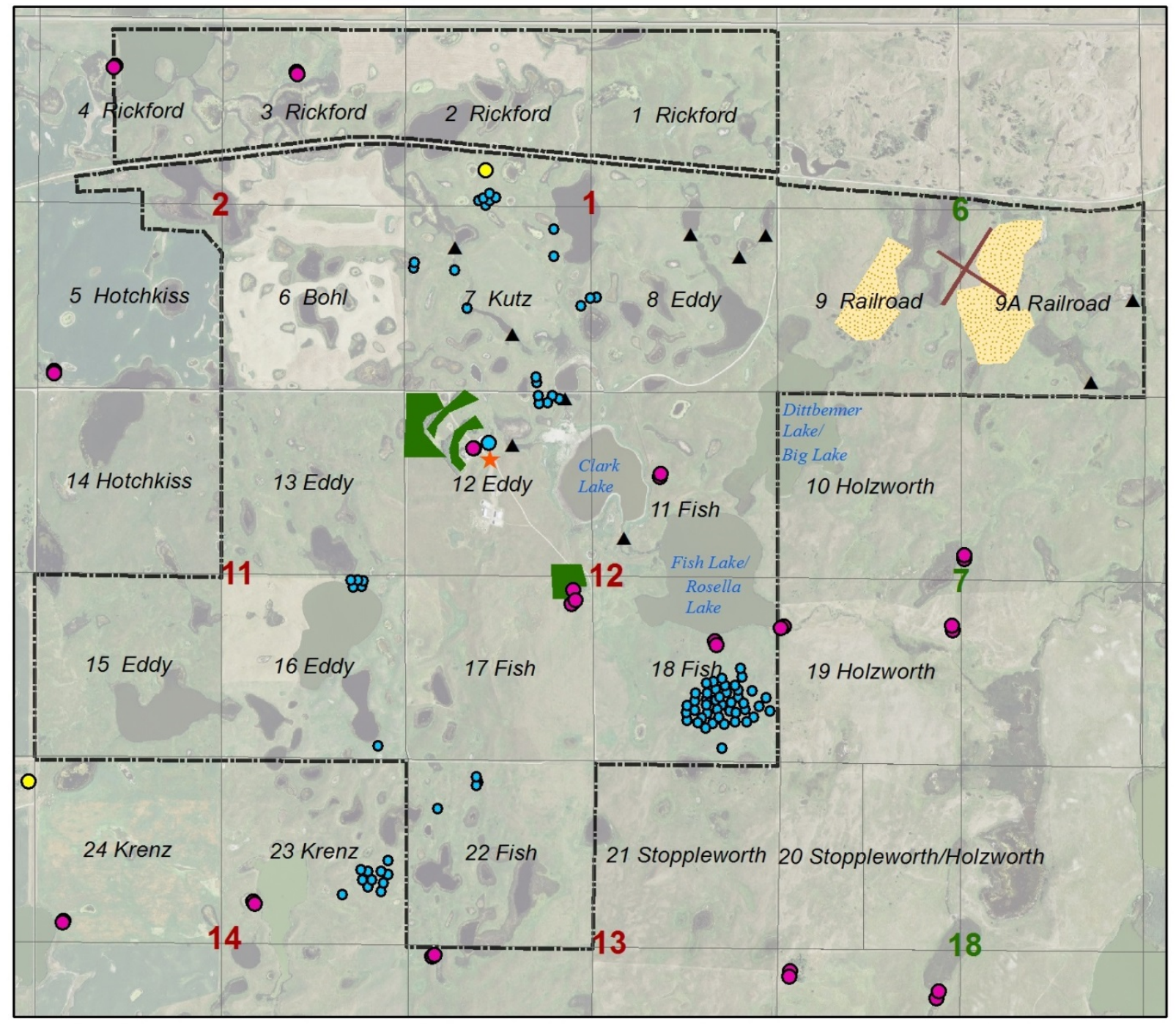

\section{Explanation}

$\star \quad$ Woodworth Study Area headquarters

- Former houses and structures

- Plat survey markers

- Teepee rings

- Dams

Airstrip (1948)

Gravel pit (1948)

Shelterbelts
-.-_-_ Boundary of Woodworth Study Area

1 Rickford Study unit, tract name

1 Section number in Strong Township

6 Section number in Paris Township

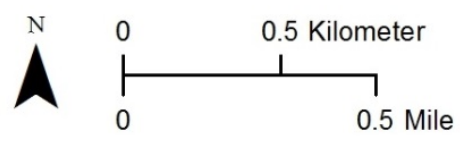




\section{Appendix 7. Location of North Dakota cities and survey sites mentioned in the text}

Jamestown is the location of the Northern Prairie Wildlife Research Center. Locations of U.S. Historical Climate Network data sites near the Woodworth Study Area are in Pettibone and Napolean, N. Dak. Dunn Center and Canfield Lake, N. Dak. were two additional sampling sites for precipitation chemistry, and Park North, Park South, and Dunn Center, N. Dak., were additional sites of air chemistry sampling in Angelo and Anderson (1983).

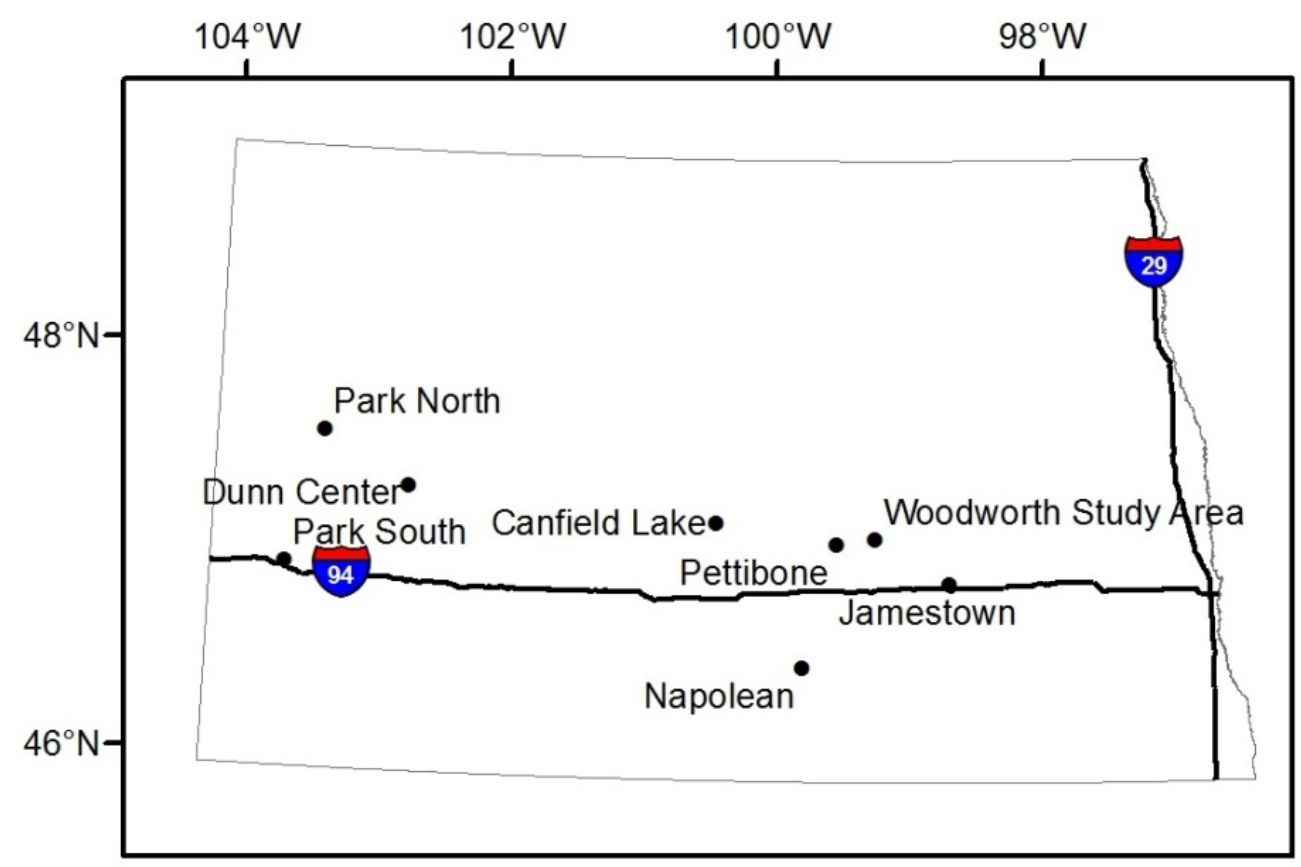




\section{Appendix 8. Geographic Information System (GIS) layers of the Woodworth Study Area (WSA) available as shapefiles}

[Feature is a general keyword description of the layer. Year is the associated time of the activity or creation of the feature; dashes indicate not applicable. Source is from where the digital file was procured. Hardcopy maps were digitized into ESRI ArcGIS ${ }^{\circledR} 10$ (ESRI, 2011) in 2013. FWS is U.S. Fish and Wildlife Service.]

\begin{tabular}{|c|c|c|c|}
\hline Feature & Years & Description & Source \\
\hline \multicolumn{4}{|c|}{ Features } \\
\hline Buildings & $\sim 1900-50$ & Homes, farms & $\begin{array}{l}\text { Bayha (written comm., } \\
\text { 1964a) }\end{array}$ \\
\hline Dams & $1960 \mathrm{~s}$ & Wetland dams & Existing file \\
\hline Water gauges & 1963-1965 & Wetland water depths & Hardcopy map \\
\hline Teepee rings & Unknown & Reported teepee rings & Hardcopy map \\
\hline Shelterbelt trees & $\sim 1900-65$ & Trees planted by settlers and staff & Archived memos \\
\hline Auto tour & $2000 s$ & Features for visitors & Existing digital file \\
\hline $\begin{array}{l}\text { Sharp-tailed } \\
\text { grouse }\end{array}$ & 1964-85 & Survey locations & Hardcopy map \\
\hline Railroad & $1912-2014$ & Northern Pacific railroad & Existing digital file \\
\hline Roads & 1900s-2014 & Main road through the WSA & Existing digital file \\
\hline Water wells & 1963 & Private wells & Huxel and Petri (1963) \\
\hline Airstrip & 1948 & Historical airstrip & $\begin{array}{l}\text { Bayha (written commun., } \\
\text { 1964a); } \\
\text { Woodworth Betterment } \\
\text { Community (1986) }\end{array}$ \\
\hline Plat markers & 1934, 1951 & Federal survey markers & http://survey.swc.nd.gov \\
\hline \multicolumn{4}{|c|}{ Treatments } \\
\hline Weed chemical & 1989 & $\begin{array}{l}\text { Leafy spurge and knapweed spray } \\
\text { treatment }\end{array}$ & Hardcopy map \\
\hline Nitrogen fertilizer & 1971-75 & $\begin{array}{l}\text { Experimental and treatment } \\
\text { applications }\end{array}$ & Hardcopy map \\
\hline Prescribed burns & 1965-90 & Areas burned by year & Hardcopy map \\
\hline Fire breaks & 1987 & Dirt, mowed, trail breaks & Hardcopy map \\
\hline Sheep grazing & 1973, 1975 & Enclosure, exclosure areas & Hardcopy map \\
\hline \multicolumn{4}{|c|}{ Geophysical } \\
\hline Permeable soils & --- & Band of few wetlands & $\begin{array}{l}\text { Bayha (written commun., } \\
\text { 1964b) }\end{array}$ \\
\hline Glacial features & --- & $\begin{array}{l}\text { Hummocky stagnation and } \\
\text { outwash border }\end{array}$ & Winters (1963) \\
\hline Physiographic & --- & Four physical regions of N. Dak. & FWS existing digital file \\
\hline Current soil series & --- & $\begin{array}{l}\text { SSURGO soils (U.S. Department } \\
\text { of Agriculture, 2011) }\end{array}$ & Existing digital file \\
\hline Wetland classes & --- & National Wetland Inventory & $\begin{array}{l}\text { FWS; Cowardin and others } \\
\text { (1979) }\end{array}$ \\
\hline
\end{tabular}




\begin{tabular}{|c|c|c|c|}
\hline Feature & Years & Description & Source \\
\hline \multicolumn{4}{|c|}{ Base layers } \\
\hline Field outlines & Pre-1960s & Pioneer fields, delineated by use & $\begin{array}{l}\text { Bayha (written commun., } \\
\text { 1964b) }\end{array}$ \\
\hline Field outlines & Post-1960s & $\begin{array}{l}\text { Fields delineated after federal } \\
\text { management }\end{array}$ & $\begin{array}{l}\text { Bayha (written commun., } \\
\text { 1964b) }\end{array}$ \\
\hline WSA border & 1975 & Federally managed land & Existing digital file \\
\hline Study units & 1975 & Study unit or quarter section lines & Existing digital file \\
\hline \multicolumn{4}{|c|}{ Vegetation transects } \\
\hline Bayha & 1963 & First upland transects at the WSA & $\begin{array}{l}\text { Bayha (written commun., } \\
\text { 1963) }\end{array}$ \\
\hline Meyer & 1980 & One year of percent cover & Hardcopy map \\
\hline $\begin{array}{l}\text { Higgins, } \\
\text { approximate }\end{array}$ & 1966 & Approximate transect locations & Existing digital file \\
\hline $\begin{array}{l}\text { Higgins, ground } \\
\text { truthed }\end{array}$ & 1966 & Existing transect end poles & $\begin{array}{l}\text { Ground truthed in } 2013 \text { by } \\
\text { K. Higgins }\end{array}$ \\
\hline Robel & 1975 & Approx. transect locations & Hardcopy maps \\
\hline $\begin{array}{l}\text { Photograph } \\
\text { stations }\end{array}$ & 1970 & Current photograph stations & Existing digital file \\
\hline \multicolumn{4}{|c|}{ Land cover } \\
\hline Bayha land cover & 1964 & Habitat types & $\begin{array}{l}\text { Bayha (written commun., } \\
\text { 1964b) }\end{array}$ \\
\hline Bayha land cover & 1963 & Upland vegetation & $\begin{array}{l}\text { Bayha (written commun., } \\
\text { 1963) }\end{array}$ \\
\hline Field land use & 1964-87 & Available as GeoJson file & Hardcopy file \\
\hline
\end{tabular}




\section{Appendix 9. Fertilizer treatments and locations at the Woodworth Study Area (WSA), 1966-}

75

[ID was arbitrarily assigned for the present report and corresponds to the location of the treatment in the map figure below. Study unit follows WSA convention. Date is the month (if known) and year of fertilizer application. Original descriptions are as written in archived notes and maps in the Northern Prairie Wildlife Research Center archives; see Conversion Factors for metric equivalents. Descriptions indicate application rates in pounds (lbs) or pounds per acre (lb/ac) of phosphorous (phos.), nitrogen $(\mathrm{N})$, or potassium (K).]

\begin{tabular}{|c|c|c|c|}
\hline ID & $\begin{array}{c}\text { Study } \\
\text { unit }\end{array}$ & Date & Original description \\
\hline A & 15 & October 1971 & $100 \mathrm{lb} / \mathrm{ac}$ actual phos., $100 \mathrm{lbs} / \mathrm{ac}$ actual $\mathrm{N}$ on $\sim 40$ acres \\
\hline B & 13 & October 1971 & 100 lb/ac actual phos., 100 lbs/ac actual N, on $\sim 40$ ac \\
\hline $\mathrm{C}$ & 6 & October 1971 & 100 lbs/acres actual phosphate on 36.80 acres \\
\hline $\mathrm{D}$ & 12 & September 1969 & 100 lbs $25-25-0$ \\
\hline $\mathrm{E}$ & 16 & 1969 & $25-25-0$ \\
\hline $\mathrm{F}$ & 16 & 1969 & $25-25-0$ \\
\hline G & 17 & September 1969 & 100 lbs $0-46-0$ \\
\hline $\mathrm{H}$ & 15 & November 1972 & 100 lbs K, 100 lbs N; 400 lbs 25-25-0/acre \\
\hline I & 17 & 1968 & 46 lbs K; 100 lbs/acre 0-46-0 \\
\hline $\mathrm{J}$ & 13 & November 1972 & 100 lbs K, 100 lbs N; 400 lbs 25-25-0/acre \\
\hline K & 6 & September 1969 & 46 lbs K; 100 lbs $0-46-0$ \\
\hline $\mathrm{L}$ & 6 & November 1972 & 100 lbs phos.; 217 lbs of $0-46-0 / a c r e$ \\
\hline M & 3 & September 1969 & 100 lbs 0-46-0; 46 lbs K \\
\hline $\mathrm{N}$ & 3 & September 1969 & 100 lbs 0-46-0; 46 lbs K \\
\hline $\mathrm{O}$ & 2 & 1969 & 25 lbs K, 25 lbs N; 100 lbs+ 25-25-0 \\
\hline $\mathrm{O}$ & 2 & October 1974 & 11-48-0, 200 lbs/acre; 96 lbs K; 22 lbs N \\
\hline$P$ & 3 & October 1974 & 200 lbs, 11-48-0; almost all covered by low areas \\
\hline Q & 1 & 1975 & 41 lbs phos; 16 lbs $N$ \\
\hline
\end{tabular}


Appendix 9 - Figure 1. Location of the fertilizer treatment on the Woodworth Study Area (WSA) between 1969 and 1975.

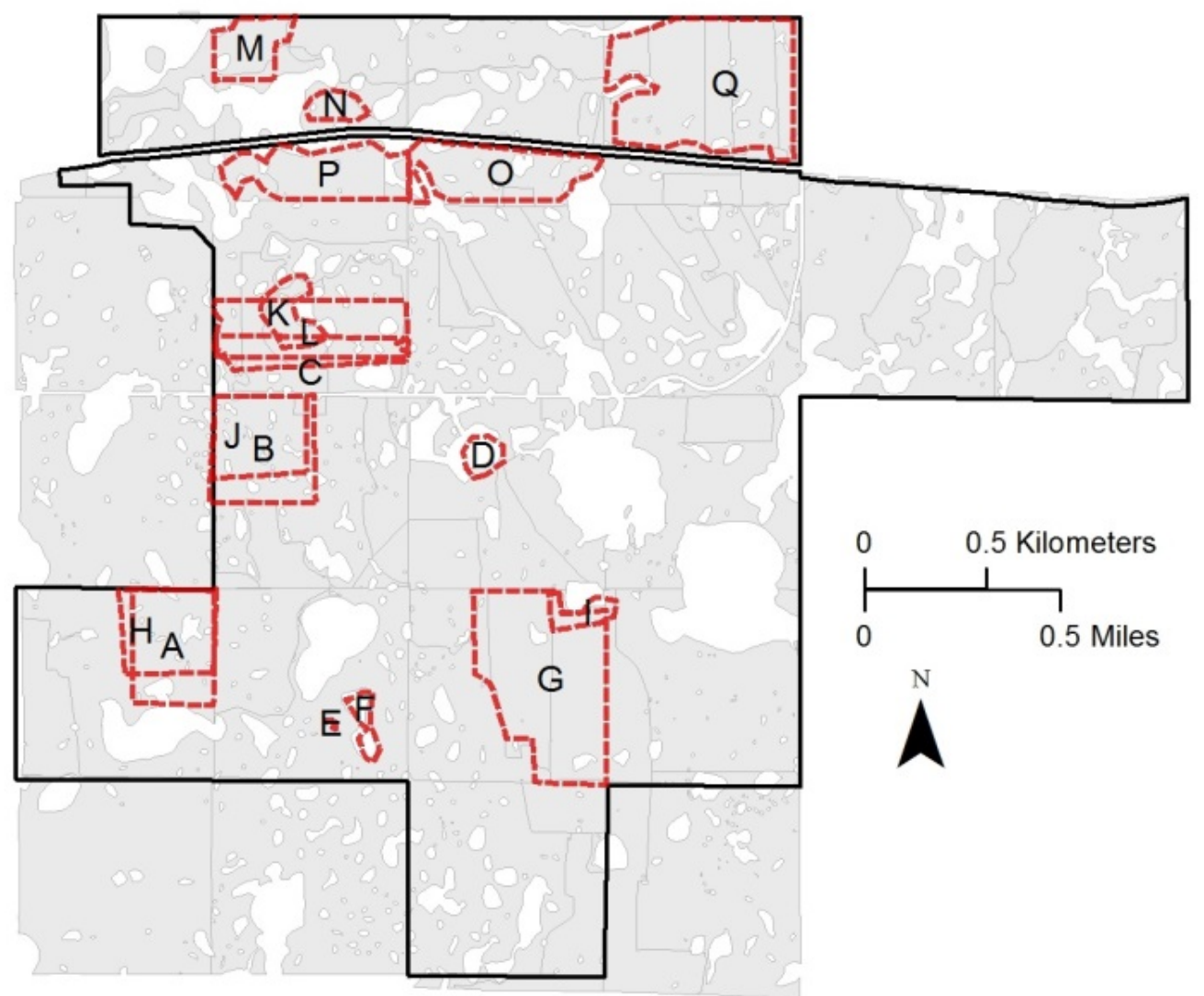




\section{Appendix 10. Master list of vegetation found at the Woodworth Study Area (WSA) during 1966-89}

[Plants that were recorded in at least one survey at the WSA during 1966-89, listed alphabetically by scientific name. Scientific species name and USDA symbol are from USDA Plant Database (2014). Common name(s) are from USDA Plant Database (2014), WSA files, or the Northern Great Plains Floristic Quality Assessment Panel (Mushet and others, 2001); INV is invasive species, UNK is unknown C value. The $C$ is coefficient of conservatism assigned by Mushet and others (2001). Functional group is sedge, forb, grass, or VST (vine, shrub, or tree).]

\begin{tabular}{|c|c|c|c|c|}
\hline Scientific name & Common name(s) & USDA & C & $\begin{array}{l}\text { Functional } \\
\text { group }\end{array}$ \\
\hline Acer negundo & boxelder & ACNE2 & 1 & VST \\
\hline Achillea millefolium & common yarrow & ACMI2 & 3 & forb \\
\hline Acroptilon repens & hardheads & ACRE3 & INV & forb \\
\hline Agalinis tenuifolia & $\begin{array}{l}\text { slenderleaf false foxglove, slender } \\
\text { gerardia }\end{array}$ & AGTEM & 8 & forb \\
\hline Agoseris glauca & pale agoseris, false dandelion & AGGL & 8 & forb \\
\hline Agoseris retrorsa & spearleaf agoseris & AGRE & UNK & forb \\
\hline Agrimonia striata & roadside agrimony, agrimony & AGST & 5 & forb \\
\hline Agropyron cristatum & crested wheatgrass & AGCR & INV & grass \\
\hline Agrostis hyemalis & winter bentgrass, ticklegrass & AGHY & 1 & grass \\
\hline Agrostis scabra & rough bentgrass & AGSC5 & 1 & grass \\
\hline Alisma gramineum & narrowleaf water plantain & ALGR & 2 & forb \\
\hline Alisma subcordatum & American water plantain & ALSU & 2 & forb \\
\hline Allium stellatum & autumn onion, pink wild onion & ALST & 7 & forb \\
\hline Allium textile & textile onion, white wild onion & ALTE & 7 & forb \\
\hline Alopecurus aequalis & shortawn foxtail & ALAE & 2 & grass \\
\hline Amaranthus retroflexus & redroot amaranth, rough pigweed & AMRE & 0 & forb \\
\hline Ambrosia psilostachya & Cuman ragweed, western ragweed & AMPS & 2 & forb \\
\hline Amelanchier alnifolia & Saskatoon serviceberry, juneberry & AMAL2 & 6 & VST \\
\hline Amorpha canescens & leadplant & AMCA6 & 9 & VST \\
\hline Amorpha fruticosa & false indigo bush & AMFR & 4 & VST \\
\hline Amorpha nana & dwarf false indigo, dwarf wild indigo & AMNA & 9 & VST \\
\hline Andropogon gerardii & big bluestem & ANGE & 5 & grass \\
\hline Androsace occidentalis & western rockjasmine & ANOC2 & 5 & forb \\
\hline Anemone canadensis & Canadian anemone, meadow anemone & ANCA8 & 4 & forb \\
\hline Anemone cylindrica & candle anemone & ANCY & 7 & forb \\
\hline Antennaria neglecta & field pussytoes & ANNE & 5 & forb \\
\hline Antennaria parvifolia & small-leaf pussytoes, pussy toes & ANPA4 & 6 & forb \\
\hline Antennaria rosea & rosy pussytoes & ANRO2 & UNK & forb \\
\hline Anthriscus caucalis & bur chervil & ANSC8 & UNK & forb \\
\hline Apocynum androsaemifolium & spreading dogbane & APAN2 & 6 & forb \\
\hline Apocynum cannabinum & Indianhemp, prairie dogbane & APCA & 4 & forb \\
\hline Arabis $\times$ divaricarpa & spreadingpod rockcress, rock cress & ARDI2 & 9 & forb \\
\hline
\end{tabular}




\begin{tabular}{|c|c|c|c|c|}
\hline Scientific name & Common name(s) & USDA & C & $\begin{array}{l}\text { Functional } \\
\text { group }\end{array}$ \\
\hline Arabis hirsuta & hairy rockcress, rock cress & ARHI & 7 & forb \\
\hline Arabis holboellii & Holboell's rockcress, rock cress & ARHO2 & 5 & forb \\
\hline Arabis spp. & rockcress & ARABI & UNK & forb \\
\hline Arctium minus & lesser burdock & ARMI2 & INV & forb \\
\hline Argentina anserina & silverweed cinquefoil, silverweed & ARAN7 & 2 & forb \\
\hline Artemisia absinthium & absinthium, wormwood & ARAB3 & INV & forb \\
\hline Artemisia biennis & biennial wormwood & ARBI2 & INV & forb \\
\hline Artemisia campestris & field sagewort, western sagebrush & ARCAC & 5 & forb \\
\hline Artemisia dracunculus & tarragon, silky wormwood & ARDR4 & 4 & forb \\
\hline Artemisia frigida & prairie sagewort & ARFR4 & 4 & VST \\
\hline Artemisia ludoviciana & white sagebrush, white sage & ARLU & 3 & forb \\
\hline Asclepias ovalifolia & oval-leaf milkweed & ASOV & 9 & forb \\
\hline Asclepias speciosa & showy milkweed & ASSP & 4 & forb \\
\hline Asclepias syriaca & common milkweed & ASSY & 0 & forb \\
\hline Asclepias verticillata & whorled milkweed & ASVE & 3 & forb \\
\hline Asclepias viridiflora & $\begin{array}{l}\text { green comet milkweed, green } \\
\text { milkweed }\end{array}$ & ASVI & 8 & forb \\
\hline Asclepias incarnata & swamp milkweed & ASIN & 5 & forb \\
\hline Asclepias pumila & plains milkweed & ASPU & 7 & forb \\
\hline Astragalus agrestis & purple milkvetch & ASAG2 & 6 & forb \\
\hline Astragalus bisulcatus & twogrooved milkvetch & ASBI2 & 5 & forb \\
\hline Astragalus canadensis & Canadian milkvetch & ASCA11 & 5 & forb \\
\hline $\begin{array}{l}\text { Astragalus canadensis var. } \\
\text { brevidense }\end{array}$ & shorttooth Canadian milkvetch & ASCAB & 5 & forb \\
\hline Astragalus crassicarpus & groundplum milkvetch & ASCR2 & 7 & forb \\
\hline Astragalus flexuosus & flexile milkvetch, slender milkvetch & ASFL2 & 4 & forb \\
\hline Astragalus gilviflorus & plains milkvetch, tufted milkvetch & ASGI5 & 7 & forb \\
\hline Astragalus laxmannii & prairie milkvetch & ASLAR & 8 & forb \\
\hline Astragalus pectinatus & narrowleaf milkvetch & ASPE5 & 8 & forb \\
\hline Astragalus racemosus & cream milkvetch & ASRA2 & 7 & forb \\
\hline Astragalus tenellus & looseflower milkvetch & ASTE5 & 8 & forb \\
\hline Astragalus lotiflorus & lotus milkvetch & ASLO4 & 6 & forb \\
\hline Avena fatua & wild oat & AVFA & INV & grass \\
\hline Avenula hookeri & spikeoat & AVHO3 & 9 & grass \\
\hline Bassia scoparia & burningbush, kochia & BASC5 & INV & forb \\
\hline Beckmannia syzigachne & American sloughgrass & BESY & 1 & grass \\
\hline Bidens frondosa & devil's beggartick, beggarticks & BIFR & 1 & forb \\
\hline Bidens vulgata & big devils beggartick, beggarticks & BIVU & 1 & forb \\
\hline Bidens comosa & threelobe beggarticks, swamp tickseed & BICO3 & 2 & forb \\
\hline Boltonia asteroides & white doll's daisy, violet boltonia & BOASL & 3 & forb \\
\hline Bouteloua curtipendula & sideoats grama & BOCU & 5 & grass \\
\hline Bouteloua gracilis & blue grama & BOGR2 & 7 & grass \\
\hline
\end{tabular}




\begin{tabular}{|c|c|c|c|c|}
\hline Scientific name & Common name(s) & USDA & C & $\begin{array}{l}\text { Functional } \\
\text { group }\end{array}$ \\
\hline Bromus arvensis & field brome, Japanese brome & BRAR5 & INV & grass \\
\hline Bromus inermis & smooth brome & BRIN2 & INV & grass \\
\hline Bromus tectorum & cheatgrass, downy brome & BRTE & INV & grass \\
\hline Calamagrostis canadensis & bluejoint & CACA4 & 5 & grass \\
\hline Calamagrostis montanensis & plains reedgrass & CAMO & 8 & grass \\
\hline Calamagrostis stricta & northern reedgrass & CASTI3 & 5 & grass \\
\hline Calamovilfa gigantea & giant sandreed & CAGI3 & UNK & grass \\
\hline Calamovilfa longifolia & prairie sandreed & CALO & 5 & grass \\
\hline Callitriche hermaphroditica & northern water-starwort & CAHE2 & 7 & forb \\
\hline Calochortus lyallii & $\begin{array}{l}\text { Lyall's mariposa lily, yellow evening } \\
\text { primrose }\end{array}$ & CALY & 7 & forb \\
\hline Calylophus serrulatus & yellow sundrops & CASE12 & 7 & forb \\
\hline Calystegia sepium & $\begin{array}{l}\text { hedge false bindweed, hedge } \\
\text { bindweed }\end{array}$ & CASEA2 & 0 & forb \\
\hline Campanula rotundifolia & bluebell bellflower, harebell & CARO2 & 7 & forb \\
\hline Capsella bursa-pastoris & shepherd's purse & CABU2 & INV & forb \\
\hline Carex atherodes & wheat sedge, slough sedge & СAAT2 & 4 & sedge \\
\hline Carex brevior & shortbeak sedge, fescue sedge & CABR10 & 4 & sedge \\
\hline Carex duriuscula & needleleaf sedge & CADU6 & 4 & sedge \\
\hline Carex filifolia & threadleaf sedge & CAFI & 7 & sedge \\
\hline Carex inops & sun sedge & CAINH2 & 7 & sedge \\
\hline Carex interior & inland sedge & CAIN11 & 10 & sedge \\
\hline Carex laxiculmis & spreading sedge & CALAC & UNK & sedge \\
\hline Carex pellita & woolly sedge & CAPE42 & 4 & sedge \\
\hline Carex pensylvanica & Pennsylvania sedge & CAPE6 & 8 & sedge \\
\hline Carex praegracilis & clustered field sedge & CAPR5 & 5 & sedge \\
\hline Carex rostrata & beaked sedge & CAR06 & 8 & sedge \\
\hline Carex aquatilis & water sedge & CAAQA5 & 10 & sedge \\
\hline Carex crawei & Crawe's sedge & CACR3 & 9 & sedge \\
\hline Carex obtusata & obtuse sedge & CAOB4 & 8 & sedge \\
\hline Carex sartwellii & Sartwell's sedge & CASA8 & 5 & sedge \\
\hline Castilleja sessiliflora & downy paintedcup & CASE5 & 8 & forb \\
\hline Castilleja coccinea & scarlet Indian paintbrush & CAC017 & UNK & forb \\
\hline Ceanothus arboreus & feltleaf ceanothus & CEAR & UNK & VST \\
\hline Celastrus scandens & American bittersweet & CESC & 5 & VST \\
\hline Centaurea maculosa & spotted knapweed & CEMA4 & INV & forb \\
\hline Cerastium arvense & field chickweed, prairie chickweed & CEAR4 & 2 & forb \\
\hline Chamaerhodos erecta & little rose & CHER & 6 & forb \\
\hline Chamaesyce serpyllifolia & $\begin{array}{l}\text { thymeleaf sandmat, thyme-leaved } \\
\text { spurge }\end{array}$ & CHSES & 0 & forb \\
\hline Chamaesyce maculata & spotted sandmat & CHMA15 & UNK & forb \\
\hline Chamaesyce serpens & matted sandmat & CHSE4 & UNK & forb \\
\hline
\end{tabular}




\begin{tabular}{|c|c|c|c|c|}
\hline Scientific name & Common name(s) & USDA & C & $\begin{array}{l}\text { Functional } \\
\text { group }\end{array}$ \\
\hline Chamerion angustifolium & fireweed & CHANA2 & 5 & forb \\
\hline Chenopodium album & lambsquarters & CHAL7 & INV & forb \\
\hline Chenopodium glaucum & oakleaf goosefoot & CHGL3 & INV & forb \\
\hline Cicuta maculata & spotted, common water hemlock & CIMA2 & 4 & forb \\
\hline Cirsium arvense & Canada thistle & CIAR4 & INV & forb \\
\hline Cirsium flodmanii & Flodman's thistle, prairie thistle & CIFL & 5 & forb \\
\hline Cirsium undulatum & wavyleaf thistle & CIUN & 7 & forb \\
\hline Cirsium vulgare & bull thistle & CIVU & INV & forb \\
\hline Cistanthe umbellata & Mt. Hood pussypaws & CIUM & UNK & forb \\
\hline Collomia linearis & tiny trumpet, collomia & COLI2 & 5 & forb \\
\hline Comandra umbellata & bastard toadflax & COUM & 8 & forb \\
\hline Convolvulus arvensis & field bindweed & COAR4 & INV & forb \\
\hline Conyza canadensis & Canadian horseweed, horseweed & COCA5 & 0 & forb \\
\hline Cornus sericea & redosier dogwood & COSES & UNK & VST \\
\hline Crataegus chrysocarpa & $\begin{array}{l}\text { fireberry hawthorn, roundleaf } \\
\text { hawthorn }\end{array}$ & $\mathrm{CRCH}$ & UNK & VST \\
\hline Crepis runcinata & fiddleleaf hawksbeard, hawk's-beard & CRRU3 & 8 & forb \\
\hline Cypripedium parviflorum & lesser yellow lady's slipper & CYPAP4 & 10 & forb \\
\hline Cypripedium parviflorum & greater yellow lady's slipper & CYPAP3 & 10 & forb \\
\hline Dalea candida & white prairie clover & DACA7 & 8 & forb \\
\hline Dalea purpurea & purple prairie clover & DAPU5 & 8 & forb \\
\hline Dalea candida & white prairie clover & DACAC & 8 & forb \\
\hline Dalea leporina & foxtail prairie clover & DALE3 & 2 & forb \\
\hline Deschampsia cespitosa & tufted hairgrass & DECE & 9 & grass \\
\hline Descurainia sophia & herb sophia, flixweed & DESO2 & INV & forb \\
\hline Dichanthelium leibergii & Leiberg's panicum & DILE2 & 8 & grass \\
\hline Dichanthelium wilcoxianum & fall rosette grass, Wilcox panicum & DIWI5 & 8 & grass \\
\hline Distichlis spicata & saltgrass & DISP & 2 & grass \\
\hline Draba nemorosa & woodland draba, yellow whitlowwort & DRNE & 1 & forb \\
\hline Echinacea angustifolia & $\begin{array}{l}\text { blacksamson echinacea, } \\
\text { purple coneflower }\end{array}$ & ECAN2 & 7 & forb \\
\hline Echinochloa crus-galli & barnyardgrass & ECCR & INV & grass \\
\hline Elaeagnus angustifolia & Russian olive & ELAN & INV & VST \\
\hline Elaeagnus commutata & silverberry & ELCO & 5 & VST \\
\hline Eleocharis acicularis & needle spikerush & ELAC & 3 & sedge \\
\hline Eleocharis erythropoda & bald spikerush & ELER & 2 & sedge \\
\hline Eleocharis palustris & common spikerush, spike rush & ELPA3 & 4 & sedge \\
\hline Eleocharis compressa & flatstem spikerush & ELCO2 & 8 & sedge \\
\hline Eleocharis macrostachya & pale spikerush & ELMA5 & 4 & sedge \\
\hline Elymus canadensis & Canada wildrye & ELCA4 & 3 & grass \\
\hline Elymus caninus & $\begin{array}{l}\text { bearded wheatgrass, slender } \\
\text { wheatgrass }\end{array}$ & ELCA11 & 6 & grass \\
\hline
\end{tabular}




\begin{tabular}{|c|c|c|c|c|}
\hline Scientific name & Common name(s) & USDA & C & $\begin{array}{l}\text { Functional } \\
\text { group }\end{array}$ \\
\hline Elyleymus hirtiflorus & Canadian wildrye & ELHI4 & UNK & grass \\
\hline Elymus lanceolatus & thickspike wheatgrass & ELLAL & 7 & grass \\
\hline Elymus repens & quackgrass & ELRE4 & INV & grass \\
\hline Elymus trachycaulus & slender wheatgrass & ELTRS & 6 & grass \\
\hline Epilobium brachycarpum & tall annual willowherb, willow herb & EPBR3 & 3 & forb \\
\hline Epilobium ciliatum & fringed willowherb & EPCIC & 3 & forb \\
\hline Epilobium palustre & $\begin{array}{l}\text { marsh willowherb, } \\
\text { narrow-leaved willow herb }\end{array}$ & EPPA & 6 & forb \\
\hline Epilobium angustifolium & fireweed & EPAN2 & 5 & forb \\
\hline Equisetum arvense & field horsetail & EQAR & 4 & forb \\
\hline Equisetum laevigatum & smooth horsetail & EQLA & 3 & forb \\
\hline Equisetum hyemale & scouringrush horsetail & EQHY & 3 & forb \\
\hline Erigeron glabellus & streamside fleabane, smooth fleabane & ERGL2 & 7 & forb \\
\hline Erigeron philadelphicus & Philadelphia fleabane & ERPH & 2 & forb \\
\hline Erigeron strigosus & prairie fleabane, daisy fleabane & ERST3 & 3 & forb \\
\hline Eriophorum viridicarinatum & thinleaf cottonsedge & ERVI9 & 10 & sedge \\
\hline Eriophorum polystachion & cottongrass & ERPO6 & 8 & sedge \\
\hline Erucastrum gallicum & common dogmustard, dog mustard & ERGA & INV & forb \\
\hline Erysimum asperum & western wallflower & ERAS2 & 3 & forb \\
\hline Erysimum cheiranthoides & wormseed wallflower & ERCH9 & INV & forb \\
\hline Erysimum inconspicuum & shy wallflower, smallflower wallflower & ERIN7 & 7 & forb \\
\hline Escobaria vivipara & spinystar, pincushion cactus & ESVIV & 10 & forb \\
\hline Eupatoriadelphus maculatus & $\begin{array}{l}\text { spotted trumpetweed, } \\
\text { spotted joe-pye-weed }\end{array}$ & EUMAM3 & 9 & forb \\
\hline Euphorbia esula & leafy spurge & EUESE & INV & forb \\
\hline Eurybia sibirica & arctic aster, simple aster & EUSI13 & 3 & forb \\
\hline Euthamia graminifolia & $\begin{array}{l}\text { flat-top goldentop, } \\
\text { narrow-leaved goldenrod }\end{array}$ & EUGRG & 6 & forb \\
\hline Festuca ovina & sheep fescue & FEOV & 8 & grass \\
\hline Fragaria virginiana & Virginia strawberry, wild strawberry & FRVI & 4 & forb \\
\hline Fumaria officinalis & drug fumitory & FUOF & UNK & forb \\
\hline Gaillardia aristata & common gaillardia, blanketflower & GAAR & 5 & forb \\
\hline Galium boreale & northern bedstraw & GABO2 & 4 & forb \\
\hline Galium trifidum & threepetal bedstraw, small bedstraw & GATR2 & 8 & forb \\
\hline Gaura coccinea & scarlet beeblossom, scarlet gaura & GACO5 & 4 & forb \\
\hline Gentiana affinis & pleated gentian, northern gentian & GEAF & 10 & forb \\
\hline Gentiana andrewsii & closed bottle gentian & GEAN & 10 & forb \\
\hline Gentianella amarella & autumn dwarf gentian & GEAM3 & 7 & forb \\
\hline Gentianopsis procera & lesser fringed gentian & GEPR6 & 10 & forb \\
\hline Geum aleppicum & yellow avens & GEAL3 & 4 & forb \\
\hline Geum triflorum & old man's whiskers, purple avens & GETR & 8 & forb \\
\hline Glyceria grandis & $\begin{array}{l}\text { American mannagrass, tall } \\
\text { mannagrass }\end{array}$ & GLGR & 4 & grass \\
\hline
\end{tabular}




\begin{tabular}{|c|c|c|c|c|}
\hline Scientific name & Common name(s) & USDA & C & $\begin{array}{l}\text { Functional } \\
\text { group }\end{array}$ \\
\hline Glyceria striata & fowl mannagrass & GLST & 6 & grass \\
\hline Glycyrrhiza lepidota & American licorice, wild licorice & GLLE3 & 2 & forb \\
\hline Graphina sophisticascens & $\begin{array}{l}\text { sophisticated graphina lichen, } \\
\text { curly-top gumweed }\end{array}$ & GRSO & 1 & forb \\
\hline Gutierrezia sarothrae & broom snakeweed & GUSA2 & 6 & VST \\
\hline Hackelia virginiana & beggarslice, Virginia stickseed & HAVI2 & 0 & forb \\
\hline Hedeoma hispida & $\begin{array}{l}\text { rough false pennyroyal, rough } \\
\text { pennyroyal }\end{array}$ & HEHI & 2 & forb \\
\hline Helianthus $\times$ laetiflorus & cheerful sunflower, stiff sunflower & HELA & UNK & forb \\
\hline Helianthus annuus & common sunflower & HEAN3 & 0 & forb \\
\hline Helianthus maximiliani & Maximilian sunflower & HEMA2 & 5 & forb \\
\hline Helianthus nuttallii & Nuttall's sunflower & HENU & 8 & forb \\
\hline $\begin{array}{l}\text { Helianthus nuttallii } \\
\text { ssp. Rydbergii }\end{array}$ & $\begin{array}{l}\text { Rydberg's sunflower, } \\
\text { Nuttall's sunflower }\end{array}$ & HENUR & 8 & forb \\
\hline Hesperis matronalis & dames rocket & HEMA3 & INV & forb \\
\hline Hesperostipa comata & needle and thread & HECOC8 & 6 & grass \\
\hline Hesperostipa spartea & porcupinegrass & HESP11 & 8 & grass \\
\hline Heterotheca camporum & $\begin{array}{l}\text { lemonyellow false goldenaster, } \\
\text { golden aster }\end{array}$ & HECAC2 & UNK & forb \\
\hline Heterotheca villosa & hairy false goldenaster & HEVIV & 3 & forb \\
\hline Heuchera richardsonii & Richardson's alumroot & HERI & 8 & forb \\
\hline Hierochloe odorata & sweetgrass & HIOD & 10 & grass \\
\hline Hippuris vulgaris & common mare's-tail, mare's-tail & HIVU2 & 5 & forb \\
\hline Hordeum jubatum & foxtail barley & HOJU & 0 & grass \\
\hline Hypoxis hirsuta & common goldstar, yellow stargrass & HYHI2 & 8 & forb \\
\hline Iva annua & annual marsh elder, marsh elder & IVAN2 & INV & forb \\
\hline Juncus arcticus & mountain rush, Baltic rush & JUARL & 5 & rush \\
\hline Juncus bufonius & toad rush & JUBU & 1 & rush \\
\hline Juncus dudleyi & Dudley's rush & JUDU2 & 4 & rush \\
\hline Juncus interior & inland rush & JUIN2 & 5 & rush \\
\hline Juncus longistylis & longstyle rush & JULO & 10 & rush \\
\hline Juncus nodosus & knotted rush & JUNO2 & 7 & rush \\
\hline Juncus torreyi & Torrey's rush & JUTO & 2 & rush \\
\hline Koeleria macrantha & prairie junegrass, junegrass & KOMA & 7 & grass \\
\hline Lactuca serriola & prickly lettuce & LASE & INV & forb \\
\hline Lactuca tatarica & blue lettuce & LATAP & 1 & forb \\
\hline Lappula occidentalis & flatspine stickseed, low stickseed & LAOCO & 2 & forb \\
\hline Lappula squarrosa & European stickseed, blue stickseed & LASQ & INV & forb \\
\hline Lathyrus ochroleucus & cream pea, yellow vetchling & LAOC2 & 8 & forb \\
\hline Lathyrus venosus & veiny pea & LAVE & 8 & forb \\
\hline Lemna minor & common duckweed & LEMI3 & 9 & forb \\
\hline Lemna trisulca & star duckweed & LETR & 2 & forb \\
\hline Lepidium densiflorum & common pepperweed, peppergrass & LEDE & 0 & forb \\
\hline
\end{tabular}




\begin{tabular}{|c|c|c|c|c|}
\hline Scientific name & Common name(s) & USDA & C & $\begin{array}{l}\text { Functional } \\
\text { group }\end{array}$ \\
\hline Lesquerella ludoviciana & foothill bladderpod, silver bladderpod & LELU & 6 & forb \\
\hline Leymus cinereus & basin wildrye & LECI4 & UNK & grass \\
\hline Liatris ligulistylis & $\begin{array}{l}\text { Rocky Mountain blazing star, gay- } \\
\text { feather }\end{array}$ & LILI & 10 & forb \\
\hline Liatris punctata & dotted blazing star, blazing star & LIPU & 7 & forb \\
\hline Lilium philadelphicum & wood lily, wild lily & LIPH & 8 & forb \\
\hline Lilium canadense & Canada lily & LICAC & 10 & forb \\
\hline Linaria vulgaris & butter and eggs & LIVU2 & INV & forb \\
\hline Linum rigidum & stiffstem flax & LIRI & 5 & forb \\
\hline Linum sulcatum & grooved flax & LISU4 & 7 & forb \\
\hline Lithospermum canescens & hoary puccoon, Indiana plant & LICA12 & 7 & forb \\
\hline Lithospermum incisum & $\begin{array}{l}\text { narrowleaf stoneseed, } \\
\text { narrow-leaved puccoon }\end{array}$ & LIIN2 & 7 & forb \\
\hline Lobelia kalmia & Ontario lobelia, Kalm's lobelia & LOKA & 10 & forb \\
\hline Lobelia spicata & palespike lobelia & LOSP & 6 & forb \\
\hline Lomatium foeniculaceum & desert biscuitroot, yellow wild parsley & LOFO & 6 & forb \\
\hline Lomatium orientale & $\begin{array}{l}\text { northern Idaho biscuitroot, wild } \\
\text { parsley }\end{array}$ & LOOR & 8 & forb \\
\hline Lonicera tatarica & Tatarian honeysuckle & LOTA & INV & VST \\
\hline Lotus unifoliolatus & $\begin{array}{l}\text { American bird's-foot trefoil, } \\
\text { prairie bird's feet trefoil }\end{array}$ & LOUNU & 3 & forb \\
\hline Lycopus americanus & $\begin{array}{l}\text { American water horehound, } \\
\text { American bugleweed }\end{array}$ & LYAM & 4 & forb \\
\hline Lycopus asper & rough bugleweed & LYAS & 4 & forb \\
\hline Lygodesmia juncea & rush skeletonplant & LYJU & 2 & forb \\
\hline Lysimachia ciliata & fringed loosestrife, fringed loosestripe & LYCI & 6 & forb \\
\hline Lysimachia hybrida & lowland yellow loosestrife, loosestrife & LYHY & 5 & forb \\
\hline Lysimachia thyrsiflora & tufted loosestrife & LYTH2 & 7 & forb \\
\hline Machaeranthera canescens & hoary tansyaster, skeleton weed & MACA2 & 2 & forb \\
\hline Machaeranthera pinnatifida & machaeranthera, spiny ironplant & MAPIS & 7 & forb \\
\hline Maianthemum stellatum & starry false lily of the valley, spikeard & MAST4 & 5 & forb \\
\hline Matricaria discoidea & disc mayweed, pineappleweed & MADI6 & INV & forb \\
\hline Medicago lupulina & black medick & MELU & INV & forb \\
\hline Medicago sativa & alfalfa & MESA & INV & forb \\
\hline Melilotus officinalis & $\begin{array}{l}\text { yellow sweetclover, white sweet } \\
\text { clover }\end{array}$ & MEOF & INV & forb \\
\hline Mentha arvensis & wild mint, field mint & MEAR4 & 3 & forb \\
\hline Mirabilis hirsuta & hairy four o'clock & MIHI & 4 & forb \\
\hline Mirabilis nyctaginea & heartleaf four o'clock & MINY & 2 & forb \\
\hline Moehringia lateriflora & bluntleaf sandwort, grove sandwort & MOLA6 & 8 & forb \\
\hline Muhlenbergia asperifolia & scratchgrass & MUAS & 2 & grass \\
\hline Muhlenbergia cuspidata & plains muhly & MUCU3 & 8 & grass \\
\hline Muhlenbergia racemosa & marsh muhly & MURA & 4 & grass \\
\hline Muhlenbergia richardsonis & mat muhly & MURI & 10 & grass \\
\hline
\end{tabular}




\begin{tabular}{|c|c|c|c|c|}
\hline Scientific name & Common name(s) & USDA & C & $\begin{array}{l}\text { Functional } \\
\text { group }\end{array}$ \\
\hline Muhlenbergia glomerata & spiked muhly & MUGL3 & 10 & grass \\
\hline Myriophyllum spicatum & shortpike watermilfoil & MYSPE & INV & forb \\
\hline Nassella viridula & green needlegrass & NAVI4 & 5 & grass \\
\hline Nepeta cataria & catnip & NECA2 & INV & forb \\
\hline Oenothera nuttallii & $\begin{array}{l}\text { Nuttall's evening primrose, white } \\
\text { stemmed evening primrose }\end{array}$ & OENU & 8 & forb \\
\hline Oenothera villosa & $\begin{array}{l}\text { hairy evening primrose, common } \\
\text { evening primrose }\end{array}$ & OEVIS & 0 & forb \\
\hline Oenothera biennis & common evening primrose & OEBI & 0 & forb \\
\hline Oligoneuron album & prairie goldenrod, sneezewort aster & OLAL2 & 5 & forb \\
\hline Oligoneuron rigidum & stiff goldenrod, rigid goldenrod & OLRIR & 4 & forb \\
\hline Onobrychis viciifolia & sainfoin & ONVI & UNK & forb \\
\hline Onosmodium bejariense & western marbleseed, false gromwell & ONBEO & 7 & forb \\
\hline Orobanche fasciculata & clustered broomrape & ORFA & 9 & forb \\
\hline Orobanche ludoviciana & Louisiana broomrape, broomrape & ORLU & 10 & forb \\
\hline Orthocarpus luteus & yellow owl's-clover, owl clover & ORLU2 & 6 & forb \\
\hline Oxalis stricta & $\begin{array}{l}\text { common yellow oxalis, yellow wood } \\
\text { sorrel }\end{array}$ & OXST & 0 & forb \\
\hline Oxytropis lambertii & purple locoweed & OXLA3 & 5 & forb \\
\hline Packera cana & woolly groundsel, gray ragwort & PACA15 & 8 & forb \\
\hline Packera plattensis & prairie groundsel, prairie ragwort & PAPL12 & 6 & forb \\
\hline Panicum capillare & witchgrass & PACA6 & 0 & grass \\
\hline Panicum virgatum & switchgrass & PAVI2 & 5 & grass \\
\hline Parnassia palustris & $\begin{array}{l}\text { marsh grass of parnassus, northern } \\
\text { grass-of-parnassus }\end{array}$ & PAPA8 & 10 & forb \\
\hline Parthenocissus quinquefolia & Virginia creeper & PAIN10 & 2 & VST \\
\hline Pascopyrum smithii & western wheatgrass & PASM & 4 & grass \\
\hline Pastinaca sativa & wild parsnip & PASA2 & INV & forb \\
\hline Pediomelum argophyllum & $\begin{array}{l}\text { silverleaf Indian breadroot, silver leaf } \\
\text { scurf pea }\end{array}$ & PEAR6 & 4 & forb \\
\hline Pediomelum esculentum & $\begin{array}{l}\text { large Indian breadroot, breadroot } \\
\text { scurf pea }\end{array}$ & PEES & 9 & forb \\
\hline Penstemon albidus & white penstemon, white beardtongue & PEAL2 & 7 & forb \\
\hline Penstemon gracilis & lilac penstemon, slender beardtongue & PEGR5 & 6 & forb \\
\hline Phacelia viscida & tacky phacelia & PHVI & UNK & forb \\
\hline Phalaris arundinacea & reed canarygrass & PHAR3 & 0 & grass \\
\hline Phleum pratense & timothy & PHPR3 & INV & grass \\
\hline Phlox hoodii & spiny phlox, hood's phlox & РHHO & 6 & forb \\
\hline Phragmites australis & common reed & PHAU7 & 0 & grass \\
\hline Physalis heterophylla & clammy groundcherry & PHHE5 & 5 & forb \\
\hline Physalis virginiana & Virginia groundcherry, ground cherry & PHVI5 & 4 & forb \\
\hline Plantago eriopoda & redwool plantain, alkali plantain & PLER & 5 & forb \\
\hline Plantago major & common plantain & PLMA2 & INV & forb \\
\hline Plantago lanceolata & narrowleaf plantain & PLLA & INV & forb \\
\hline
\end{tabular}




\begin{tabular}{|c|c|c|c|c|}
\hline Scientific name & Common name(s) & USDA & C & $\begin{array}{l}\text { Functional } \\
\text { group }\end{array}$ \\
\hline Platanthera aquilonis & northern green orchid & PLAQ2 & 9 & forb \\
\hline Poa compressa & Canada bluegrass & POCO & INV & grass \\
\hline Poa nemoralis & inland bluegrass & PONEI2 & 5 & grass \\
\hline Poa paludigena & bog bluegrass & POPA & UNK & grass \\
\hline Poa palustris & fowl bluegrass & POPA2 & 4 & grass \\
\hline Poa pratensis & Kentucky bluegrass & POPR & INV & grass \\
\hline Polygala alba & white milkwort & POAL4 & 5 & forb \\
\hline Polygala senega & Seneca snakeroot & POSE3 & 10 & forb \\
\hline Polygala verticillata & whorled milkwort & POVE & 8 & forb \\
\hline Polygonatum biflorum & smooth Solomon's seal & POBI2 & 8 & forb \\
\hline Polygonum achoreum & leathery knotweed, erect knotweed & POAC3 & INV & forb \\
\hline Polygonum aviculare & $\begin{array}{l}\text { prostrate knotweed, common } \\
\text { knotweed }\end{array}$ & POAV & 0 & forb \\
\hline Polygonum convolvulus & black bindweed, wild buckwheat & POC010 & INV & VST \\
\hline Polygonum lapathifolium & curlytop knotweed, pale smartweed & POLA4 & 1 & forb \\
\hline Polygonum persicaria & spotted ladysthumb, lady's thumb & POPE3 & INV & forb \\
\hline Polygonum amphibium & water smartweed & POAMS & 6 & forb \\
\hline Pontederia cordata & pickerelweed & P0C014 & UNK & forb \\
\hline Populus deltoides & eastern cottonwood, cottonwood & PODE3 & 3 & VST \\
\hline Portulaca oleracea & little hogweed & POOL & INV & forb \\
\hline Potamogeton gramineus & variableleaf pondweed & POGR8 & 6 & forb \\
\hline Potamogeton pusillus & small pondweed & POPUP5 & 2 & forb \\
\hline Potamogeton richardsonii & Richardson's pondweed & PORI2 & 4 & forb \\
\hline Potentilla arguta & tall cinquefoil & POAR7 & 8 & forb \\
\hline Potentilla concinna & elegant cinquefoil, early cinquefoil & P0C013 & 8 & forb \\
\hline Potentilla gracilis & slender cinquefoil, graceful cinquefoil & POGR9 & 5 & forb \\
\hline Potentilla hickmanii & $\begin{array}{l}\text { Hickman's cinquefoil, woolly } \\
\text { cinquefoil }\end{array}$ & POHI5 & 8 & forb \\
\hline Potentilla norvegica & $\begin{array}{l}\text { Norwegian cinquefoil, } \\
\text { strawberryweed }\end{array}$ & PONO3 & 0 & forb \\
\hline Potentilla pensylvanica & Pennsylvania cinquefoil & POPE8 & 9 & forb \\
\hline Potentilla rivalis Nutt. & brook cinquefoil & PORI3 & 3 & forb \\
\hline Potentilla concinna & elegant cinquefoil & POCOC3 & 8 & forb \\
\hline Prenanthes racemosa & purple rattlesnakeroot & PRRA & 10 & forb \\
\hline Prunus americana & American plum, wild plum & PRAM & 4 & VST \\
\hline Prunus virginiana & chokecherry & PRVI & 4 & VST \\
\hline Puccinellia nuttalliana & Nuttall's alkaligrass, alkali grass & PUNU2 & 4 & grass \\
\hline Pulsatilla patens & cutleaf anemone, pasque-flower & PUPAM & 9 & forb \\
\hline Ranunculus glaberrimus & $\begin{array}{l}\text { sagebrush buttercup, } \\
\text { shiny-leaved buttercup }\end{array}$ & RAGL & 8 & forb \\
\hline Ranunculus macounii & Macoun's buttercup & RAMA2 & 4 & forb \\
\hline Ranunculus rhomboideus & Labrador buttercup, prairie buttercup & RARH & 8 & forb \\
\hline Ranunculus aquatilis & white water crowfoot & RAAQ & UNK & forb \\
\hline
\end{tabular}




\begin{tabular}{|c|c|c|c|c|}
\hline Scientific name & Common name(s) & USDA & C & $\begin{array}{l}\text { Functional } \\
\text { group }\end{array}$ \\
\hline Ranunculus cymbalaria & alkali buttercup & RACY & 3 & forb \\
\hline Ranunculus flabellaris & yellow water buttercup & RAFL & 7 & forb \\
\hline Ranunculus gmelinii & Gmelin's buttercup & RAGM & 8 & forb \\
\hline Ranunculus longirostris & longbeak buttercup & RASU & 7 & forb \\
\hline Ranunculus sceleratus & cursed buttercup & RASC3 & 3 & forb \\
\hline Ratibida columnifera & $\begin{array}{l}\text { upright prairie coneflower, } \\
\text { prairie coneflower }\end{array}$ & RACO3 & 3 & forb \\
\hline Rhamnus cathartica & common buckthorn & RHCA3 & INV & VST \\
\hline Ribes americanum & $\begin{array}{l}\text { American black currant, wild black } \\
\text { currant }\end{array}$ & RIAM2 & 7 & VST \\
\hline Ribes missouriense & Missouri gooseberry & RIMI & 4 & VST \\
\hline Rorippa palustris & bog yellowcress & ROPA2 & 2 & forb \\
\hline Rosa arkansana & prairie rose, prairie wild rose & ROAR3 & 3 & VST \\
\hline Rosa woodsii & Woods' rose, western wild rose & ROWO & 5 & VST \\
\hline Rubus idaeus & grayleaf red raspberry & RUIDS2 & 5 & VST \\
\hline Rudbeckia hirta & blackeyed susan & RUHI2 & 5 & forb \\
\hline Rumex aquaticus & western dock & RUAQF & 7 & forb \\
\hline Rumex crispus & curly dock & RUCR & INV & forb \\
\hline Rumex longifolius & dooryard dock & RULO2 & INV & forb \\
\hline Rumex maritimus & golden dock & RUMA4 & 1 & forb \\
\hline Rumex salicifolius & Mexican dock, willow-leaved dock & RUSAM & 1 & forb \\
\hline Sagittaria cuneata & arumleaf arrowhead & SACU & 6 & forb \\
\hline Salix discolor & pussy willow & SADI & 7 & VST \\
\hline Salsola kali & Russian thistle & SAKA & INV & forb \\
\hline Schedonnardus paniculatus & tumblegrass & SCPA & 1 & grass \\
\hline Schizachyrium scoparium & little bluestem & SCSC & 6 & grass \\
\hline Schoenoplectus acutus & hardstem bulrush & SCACA & 5 & sedge \\
\hline Schoenoplectus fluviatilis & river bulrush & SCFL11 & UNK & sedge \\
\hline Schoenoplectus tabernaemontani & softstem bulrush & SCVA & 3 & sedge \\
\hline Scirpu americanus & chairmaker's bulrush & SCAM2 & UNK & sedge \\
\hline Scirpus atrovirens & green bulrush & SCAT2 & 5 & sedge \\
\hline Scolochloa festucacea & common rivergrass, sprangletop & SCFE & 6 & grass \\
\hline Scutellaria galericulata & marsh skullcap & SCGA & 7 & forb \\
\hline Senecio congestus & marsh fleabane, swamp ragwort & SECO2 & 2 & forb \\
\hline Senecio integerrimus & $\begin{array}{l}\text { lambstongue ragwort, } \\
\text { entire-leaved groundsel }\end{array}$ & SEIN2 & 7 & forb \\
\hline Senecio pseudoarnica & seaside ragwort, falsegold groundsel & SEPS & 5 & forb \\
\hline Setaria pumila & yellow foxtail & SEPUP2 & INV & grass \\
\hline Setaria viridis & green bristlegrass & SEVI4 & INV & grass \\
\hline Silene csereii & Balkan catchfly, smooth catchfly & SICS & INV & forb \\
\hline Silene latifolia & bladder campion, white cockle & SILAA3 & INV & forb \\
\hline Silene noctiflora & $\begin{array}{l}\text { nightflowering silene, } \\
\text { night-flowering catchfly }\end{array}$ & SINO & INV & forb \\
\hline
\end{tabular}




\begin{tabular}{|c|c|c|c|c|}
\hline Scientific name & Common name(s) & USDA & C & $\begin{array}{l}\text { Functional } \\
\text { group }\end{array}$ \\
\hline Sinapis arvensis & wild mustard, charlock & SIARA & INV & forb \\
\hline Sisymbrium altissimum & tall tumblemustard, tumbling mustard & SIAL2 & INV & forb \\
\hline Sisyrinchium angustifolium & $\begin{array}{l}\text { narrowleaf blue-eyed grass, } \\
\text { blue eyed grass }\end{array}$ & SIAN3 & UNK & forb \\
\hline Sisyrinchium montanum & strict blue-eyed grass & SIMO2 & 8 & forb \\
\hline Sium suave & hemlock waterparsnip & SISU2 & 3 & forb \\
\hline Smilax herbacea & smooth carrionflower, carrion-flower & SMHE & 8 & VST \\
\hline Solanum americanum & American black nightshade & SOAM & UNK & forb \\
\hline Solanum campechiense & redberry nightshade & SOCA & UNK & forb \\
\hline Solanum nigrum & black nightshade & SONI & 0 & forb \\
\hline Solanum triflorum & cutleaf nightshade & SOTR & 0 & forb \\
\hline Solidago arguta & Atlantic goldenrod & SOAR & UNK & forb \\
\hline Solidago canadensis & Canada goldenrod & SOCA6 & 1 & forb \\
\hline Solidago gigantea & giant goldenrod & SOGI & 4 & forb \\
\hline Solidago missouriensis & Missouri goldenrod, prairie goldenrod & SOMI2 & 5 & forb \\
\hline Solidago mollis & velvety goldenrod, soft goldenrod & SOMO & 6 & forb \\
\hline Solidago nemoralis & gray goldenrod & SONE & 6 & forb \\
\hline Sonchus arvensis & field sowthistle, field sow thistle & SOAR2 & INV & forb \\
\hline Sonchus oleraceus & common sowthistle & SOOL & INV & forb \\
\hline Sorghastrum nutans & Indiangrass & SONU2 & 6 & grass \\
\hline Sparganium eurycarpum & broadfruit bur-reed, giant burreed & SPEU & 4 & forb \\
\hline Spartina gracilis & alkali cordgrass & SPGR & 6 & grass \\
\hline Spartina pectinata & prairie cordgrass & SPPE & 5 & grass \\
\hline Sphaeralcea coccinea & scarlet globemallow, red false mallow & SPCO & 4 & forb \\
\hline Sphenopholis obtusata & $\begin{array}{l}\text { prairie wedgescale, prairie } \\
\text { wedgegrass }\end{array}$ & SPOB & 7 & grass \\
\hline Spiraea alba & white meadowsweet, meadowsweet & SPAL2 & 7 & VST \\
\hline Sporobolus compositus & composite dropseed, rough dropseed & SPCOC2 & 4 & grass \\
\hline Sporobolus cryptandrus & sand dropseed & SPCR & 6 & grass \\
\hline Sporobolus heterolepis & prairie dropseed & SPHE & 10 & grass \\
\hline Stachys palustris & marsh hedgenettle, hedge nettle & STPA & 3 & forb \\
\hline Stellaria longifolia & $\begin{array}{l}\text { longleaf starwort, long-leaved } \\
\text { stitchwort }\end{array}$ & STLO & 8 & forb \\
\hline Stellaria media & common chickweed & STME2 & INV & forb \\
\hline Stuckenia pectinata & sago pondweed & STPE15 & 4 & forb \\
\hline Symphoricarpos occidentalis & western snowberry & SYOC & 3 & VST \\
\hline Symphoricarpos orbiculatus & coralberry & SYOR & UNK & VST \\
\hline Symphyotrichum boreale & northern bog aster, rush aster & SYBO2 & 10 & forb \\
\hline Symphyotrichum ericoides & white heath aster & SYERE & UNK & forb \\
\hline Symphyotrichum laeve & smooth blue aster & SYLAL3 & 5 & forb \\
\hline Syringa vulgaris & common lilac & SYVU & UNK & VST \\
\hline Taraxacum laevigatum & rock dandelion, red-seeded dandelion & TALA2 & INV & forb \\
\hline
\end{tabular}




\begin{tabular}{|c|c|c|c|c|}
\hline Scientific name & Common name(s) & USDA & C & $\begin{array}{l}\text { Functional } \\
\text { group }\end{array}$ \\
\hline Taraxacum officinale & common dandelion, dandelion & TAOF & INV & forb \\
\hline Teucrium canadense & Canada germander & TECA3 & 3 & forb \\
\hline Thalictrum dasycarpum & purple meadow-rue & THDA & 7 & forb \\
\hline Thinopyrum intermedium & intermediate wheatgrass & THIN6 & INV & grass \\
\hline Thinopyrum ponticum & tall wheatgrass & THPO7 & INV & grass \\
\hline Thlaspi arvense & field pennycress, penny cress & THAR5 & INV & forb \\
\hline Toxicodendron rydbergii & western poison ivy & TORY & 3 & VST \\
\hline Tragopogon dubius & yellow salsify, goatsbeard & TRDU & INV & forb \\
\hline Trifolium hybridum & alsike clover & TRHY & INV & forb \\
\hline Trifolium repens & white clover & TRRE3 & INV & forb \\
\hline Triglochin maritima & seaside arrowgrass & TRMA20 & 5 & grass \\
\hline Typha angustifolia & narrowleaf cattail & TYAN & INV & forb \\
\hline Typha latifolia & broadleaf cattail & TYLA & 2 & forb \\
\hline Urtica dioica & stinging nettle & URDI & 0 & forb \\
\hline Utricularia vulgaris & common bladderwort & UTVU & 2 & forb \\
\hline Verbena bracteata & bigbract verbena, bracted vervain & VEBR & 0 & forb \\
\hline Verbena hastata & swamp verbena, blue vervain & VEHA2 & 5 & forb \\
\hline Verbena stricta & hoary verbena & VEST & 2 & forb \\
\hline Vernonia fasciculata & prairie ironweed & VEFA2 & 3 & forb \\
\hline Vicia americana & American vetch & VIAM & 6 & VST \\
\hline Viola adunca & hookedspur violet, small blue violet & VIAD & 8 & forb \\
\hline Viola nuttallii & Nuttall's violet & VINU2 & 8 & forb \\
\hline Viola pedata & birdfoot violet & VIPE & UNK & forb \\
\hline Viola pedatifida & prairie violet & VIPE2 & 8 & forb \\
\hline Viola nephrophylla & northern bog violet & VINE & 8 & forb \\
\hline Zannichellia palustris & horned pondweed & ZAPA & 2 & forb \\
\hline Zigadenus elegans & mountain deathcamas, white camass & ZIEL2 & 8 & forb \\
\hline Zigadenus venenosus & meadow deathcamas, death camass & ZIVE & 7 & forb \\
\hline Zizia aptera & meadow zizia, meadow parsnip & ZIAP & 8 & forb \\
\hline
\end{tabular}




\section{Appendix 11. Plants collected at the Woodworth Study Area (WSA) and stored in the Northern Prairie Wildlife Research Center herbarium}

[Plant scientific names are those recorded at the time of collection; taxonomy was primarily based on Gray's Manual of Botany (Fernald, 1950). U.S. Department of Agriculture (USDA) acronyms reflect accepted taxonomy as of 2014; see Appendix 10 for accepted scientific and common names. Collector is the staff or researcher at WSA who collected the sample, listed by their initials: AB = Allison Banks, CS = Charles Schaiffer, EL $=$ Eric Larsen, KH $=$ Kenneth F. Higgins, LHM = Lyla (Hotchkiss) Martin, MM = Mavis Meyer, MC = Michael Callow, RK = R.O. Kologiski, and WB = William J. Berg. Date is the date of plant collection. Location and original description are notes as recorded by the collectors. Location is described by field or plat location: $\mathrm{T}=\mathrm{Township}$ (north [N]), $\mathrm{R}$ = Range (west [W]), sec= section, quarter (qtr). Later locations were determined by geographic position unit (GPS) and described by Universal Transverse Locator (UTM) system in zone 14: meters east (mE) and north $(\mathrm{mN})$. Other abbreviations in the description include vegetation height (meters, m; decimeters, dm); W.P.A. is Waterfowl Production Area; slope angle, deg. is degree; and DNC is dense nesting cover.]

\begin{tabular}{|c|c|c|c|c|}
\hline Scientific name & $\begin{array}{c}\text { USDA } \\
\text { acronym }\end{array}$ & Collector & Date & Location and original description \\
\hline Acer negundo & ACNE2 & MM & 25-May-79 & $\begin{array}{l}\text { Shelterbelt south of station building. Quarter } 12 \text {. UTM: } 81,950 \mathrm{mE}, 19,600 \mathrm{mN} \text {, } \\
\text { zone } 14 \text {. }\end{array}$ \\
\hline Acer negundo & ACNE2 & $\mathrm{AB}$ & 18-Jun-79 & $\begin{array}{l}\text { Old farmstead, along road ditch. Tree, } 10 \mathrm{~m} \text { tall. Quarter } 4 . \text { UTM: } 80,700 \mathrm{mE} \text {, } \\
21,880 \mathrm{mN} \text {, zone } 14 \text {. }\end{array}$ \\
\hline Acer negundo & ACNE2 & MC & 6-May-80 & In Quarter 3 at the Rickford farm site. Tree planting. \\
\hline Agropyron caninum & ELCA11 & MM, MC & 16-Jul-80 & Located in Quarter 13 in Buse Soil on dry prairie hill. \\
\hline Agropyron caninum & ELCA11 & $\mathrm{KH}$ & 16-Aug-81 & $\begin{array}{l}\text { Located } 3 \text { miles East of Woodworth on WSA in Quarter 9-A, T142N, R67W, } \\
\text { Sec. 6. On sandy gravely soils. }\end{array}$ \\
\hline Agropyron caninum & ELCA11 & $\mathrm{KH}$ & 16-Aug-81 & $\begin{array}{l}\text { Located } 3 \text { miles East of Woodworth on WSA in Quarter 9-A, T142N, R67W, } \\
\text { Sec.6. On sandy gravely soil. }\end{array}$ \\
\hline Agropyron cristatum & AGCR & KH, EL & 22-Jun-78 & Native grassland on the Woodworth Study Area 3-East of Woodworth. \#146 \\
\hline Agropyron cristatum & AGCR & $\mathrm{AB}$ & 24-Jul-79 & Located in Quarter 9-A on the old airstrip. Plant to 1m. Tall. \\
\hline Agropyron dasystachyum & ELLAL & MM & 12-Jul-79 & Wet Meadow. Quarter 20, NW1/4. \\
\hline Agropyron elongatum & THPO7 & $\mathrm{KH}$ & 16-Aug-81 & $\begin{array}{l}\text { Located } 3 \text { miles East of Woodworth on WSA in Quarter 14, T142N, R68W, } \\
\text { Sec. 11. Collected on a seeded road right-of-way. }\end{array}$ \\
\hline Agropyron repens & ELRE4 & $\mathrm{KH}, \mathrm{MC}$ & 1-Jul-80 & Located in Quarter 9-A in low area. \\
\hline Agropyron smithii & PASM & MM & 14-Jul-80 & Located in Quarter 7 on East facing slope in Barnes Soil. \\
\hline
\end{tabular}




\begin{tabular}{|c|c|c|c|c|}
\hline Scientific name & $\begin{array}{c}\text { USDA } \\
\text { acronym }\end{array}$ & Collector & Date & Location and original description \\
\hline Agrostis hyemalis & AGHY & $\mathrm{AB}$ & 17-Jul-79 & Dry prairie hillside. Quarter 22. UTM: 81, 520mE, 18, 770mN, zone 14. \\
\hline Agrostis hyemalis & AGHY & $\mathrm{MC}, \mathrm{KH}$ & 1-Jul-80 & Located in Quarter 9-A in low moist prairie. \\
\hline Agrostis hyemalis & AGHY & MM & 29-Jul-80 & Located in Quarter 9-A. \\
\hline Agrostis hyemalis & AGHY & MM & 8-Jul-81 & Located in Quarter 22 growing on exposed soil in dry wetland. \\
\hline Agrostis hyemalis & AGHY & MM & 8-Jul-81 & $\begin{array}{l}\text { Located } 3 \text { miles East of Woodworth on WSA in Quarter 22, T142N, R68W, } \\
\text { Sec.13. On exposed soils in a dry wetland. }\end{array}$ \\
\hline Alisma plantago-aquatica & ALSU & $\mathrm{AB}$ & 12-Jul-79 & $\begin{array}{l}\text { Growing in standing water in marshy pothole. Petals white. Plants to } 1 \mathrm{~m} \text { tall } \\
\text { Quarter 2. UTM: } 82,000 \mathrm{mE}, 21,750 \mathrm{mN} \text {, zone } 14 .\end{array}$ \\
\hline Alisma plantago-aquatica & ALSU & $\mathrm{AB}$ & 12-Jul-79 & $\begin{array}{l}\text { Growing in standing water in marshy pothole. Petals white. Plants to } 1 \mathrm{~m} \text { tall } \\
\text { Quarter 2. UTM: } 82,000 \mathrm{mE}, 21,750 \mathrm{mN} \text {, zone } 14 .\end{array}$ \\
\hline Allium stellalum & ALST & $\mathrm{AB}$ & 1-Aug-79 & $\begin{array}{l}\text { Upland prairie, burned in Spring. Silty loam. Flowers pink with Andropogon } \\
\text { gerardi. Quarter 18. UTM: 82, 240mE, 19, 050mN, zone14. }\end{array}$ \\
\hline Allium stellalum & ALST & $\mathrm{AB}$ & 1-Aug-79 & $\begin{array}{l}\text { Upland prairie, burned in Spring. Silty loam. Flowers pink with Andropogon } \\
\text { gerardi. Quarter 18. UTM: 82, 240mE, 19, 050mN, zone14. }\end{array}$ \\
\hline Allium stellalum & ALST & MM, MC & 6-Aug-80 & Located in Quarter 9-A in Svea Soil. \\
\hline Allium textile & ALTE & KH, EL & 18-May-78 & Native grassland on the Woodworth Study Area 3-East of Woodworth. \#105 \\
\hline Allium textile & ALTE & MM & 13-May-81 & Located in Quarter 18. Fairly common on dry prairie, flowers white. \\
\hline Allium textile & ALTE & MM & 13-May-81 & Located in Quarter 18. Fairly common on dry prairie, flowers white. \\
\hline Alopecurus aequalis & ALAE & MM & 20-Aug-79 & $\begin{array}{l}\text { Growing in } 1.5 \text { feet of water. Wetland 3, Quarter 9. UTM: 82, 900mE, 21, } \\
250 \mathrm{mN} \text {, zone } 14 .\end{array}$ \\
\hline Alopecurus aequalis & ALAE & MM & 17-Jun-80 & West shore of Fish Lake in Quarter 12 on the Woodworth Study Area. \\
\hline Andropogon gerardi & ANGE & $\mathrm{AB}$ & 1-Aug-79 & $\begin{array}{l}\text { Moist base of hill near pothole, in silty clay loam. To } 1.6 \mathrm{~m} \text { tall. Quarter } 16 . \\
\text { UTM: } 81,200 \mathrm{mE}, 19,240 \mathrm{mN} \text {, zone } 14 .\end{array}$ \\
\hline Andropogon gerardi & ANGE & MM & 29-Jul-80 & Located in Quarter 9. \\
\hline Andropogon scoparius & SCSC & $\mathrm{AB}$ & 30-Aug-79 & $\begin{array}{l}\text { Damp lowland prairie. Bunch grass to } 1 \mathrm{~m} \text { tall. Quarter 22. UTM: } 81,730 \mathrm{mE} \text {, } \\
\text { 19, } 580 \mathrm{mN} \text {, zone } 14 \text {. }\end{array}$ \\
\hline Andropogon scoparius & SCSC & MM & 29-Jul-80 & Located in Quarter 9 in Barnes Soil. \\
\hline Andropogon scoparius & SCSC & MM & 29-Jul-80 & Located in Quarter 9 in Barnes Soil. \\
\hline Andropogon scoparius & SCSC & MM & 15-Aug-80 & Located in Quarter 22 in Hamerly Soil. \\
\hline Andropogon scoparius & SCSC & MM & 15-Aug-80 & Located in Quarter 22 in Hamerly Soil. \\
\hline Asclepias incarnata & ASIN & $\mathrm{KH}$ & 24-Jun-80 & Located in Quarter 22 along 22-18. \\
\hline Asclepias ovalifolia & ASOV & $\mathrm{KH}, \mathrm{EL}$ & 21-Jun-78 & Native grassland on the Woodworth Study Area 3-East of Woodworth. \#140 \\
\hline Asclepias ovalifolia & ASOV & $\mathrm{AB}$ & 28-Jun-79 & $\begin{array}{l}\text { Damp depression between } 2 \text { hills leading to pothole. E. } 30 \text { deg. slope. Flowers } \\
\text { greenish white, plant 2-3 dm tall. Quarter 8. UTM: } 82,110 \mathrm{mE}, 20,880 \mathrm{mN} \text {, zone } \\
14 .\end{array}$ \\
\hline Asclepias ovalifolia & ASOV & $\mathrm{KH}$ & 27-Jul-79 & Kutz W.P.A.- DNC in Woodworth, North Dakota in Stutsman County. \\
\hline
\end{tabular}




\begin{tabular}{|c|c|c|c|c|}
\hline Scientific name & $\begin{array}{c}\text { USDA } \\
\text { acronym }\end{array}$ & Collector & Date & Location and original description \\
\hline Asclepias ovalifolia & ASOV & $\mathrm{KH}, \mathrm{MC}$ & 28-Jul-79 & $\begin{array}{l}\text { Native grassland on the Kutz W.P.A.- DNC field in Woodworth, North Dakota. } \\
\# 615\end{array}$ \\
\hline Asclepias ovalifolia & ASOV & MM & 18-Jun-80 & $\begin{array}{l}\text { Growing in lowland with Anemone canadensis. Quarter 9. UTM: 82,800mE, } \\
\text { 20,800mN. }\end{array}$ \\
\hline Asclepias syriaca & ASSY & MM & 28-Jul-81 & $\begin{array}{l}\text { Located in Quarter 9-A in low area with Bromus inermis. Flowers pale } \\
\text { pink/purple. }\end{array}$ \\
\hline Asclepias verticillata & ASVE & MC & 25-Jul-80 & $\begin{array}{l}\text { Located in Quarter 9-A in association with Andropogon and Sorghastrum. } \\
\text { Flowers white. }\end{array}$ \\
\hline Asclepias verticillata & ASVE & MM & 29-Jul-80 & $\begin{array}{l}\text { Located in Quarter } 9 \text { with Liatrus ligulistylis. Site has high water table in } \\
\text { undisturbed native prairie. }\end{array}$ \\
\hline Avena fatua & AVFA & MM, CS & 28-Jul-81 & Located in Quarter 8 growing near field. \\
\hline Bouteloua curtipendula & BOCU & $\mathrm{AB}$ & 1-Aug-79 & $\begin{array}{l}\text { Upland prairie hillside, burned in spring. 3-5dm tall. With Bouteloua gracilis. } \\
\text { Quarter 16. UTM: 81, 160mE, 19, 180mN, zone } 14 .\end{array}$ \\
\hline Bouteloua curtipendula & BOCU & MM & 14-Jun-80 & Located in Quarter 7 on East facing slope in Barnes Soil. \\
\hline Bouteloua curtipendula & BOCU & MM & 14-Jun-80 & Located in Quarter 7 on East facing slope in Barnes Soil. \\
\hline Bouteloua curtipendula & BOCU & $\mathrm{KH}$ & 13-Aug-81 & $\begin{array}{l}\text { Located } 3 \text { miles East of Woodworth on WSA in Quarter 4, T142N, R68W, Sec. } \\
\text { 2. In good soil along west side of 3-5 by crossing, east facing slope. }\end{array}$ \\
\hline Bouteloua curtipendula & BOCU & $\mathrm{KH}$ & 13-Aug-81 & $\begin{array}{l}\text { Located } 3 \text { miles East of Woodworth on WSA in Quarter 4, T142N, R68W, Sec. } \\
\text { 2. In good soil along west side of 3-5 by crossing, east facing slope. }\end{array}$ \\
\hline Bouteloua gracilis & BOGR2 & MM & 18-Jul-79 & $\begin{array}{l}\text { Growing on dry sites in mixed grass native prairie. Quarter 12. UTM: } 81 \text {, } \\
600 \mathrm{mE}, 19,800 \mathrm{mN} \text {, zone } 14 .\end{array}$ \\
\hline Bouteloua gracilis & BOGR2 & MM & 7-Jul-80 & Located in Quarter 9-A in Sioux soils. \\
\hline Bromus inermis & BRIN2 & MM & 18-Jun-80 & With Symphorocarpus occidentalis in Quarter 22. \\
\hline Bromus inermis & BRIN2 & MC & 23-Jun-80 & Located in Quarter 22. \\
\hline Bromus japonicus & BRAR5 & $\mathrm{AB}$ & 10-Jul-79 & $\begin{array}{l}\text { Steep, dry bank near gravel pit. Quarter 9. UTM: 83, 080mE, 20, 780mN, zone } \\
14 .\end{array}$ \\
\hline Bromus japonicus & BRAR5 & MM & 30-Jun-81 & $\begin{array}{l}\text { Located } 3 \text { miles East of Woodworth on WSA in Quarter 9, T142N, R67W, Sec. } \\
\text { 6. In gravel pit area on thin soils. }\end{array}$ \\
\hline Bromus japonicus & BRAR5 & MM & 30-Jun-81 & Located in Quarter 9 in the gravel pit area. \\
\hline Carex atherodes & CAAT2 & KH, EL & 22-Jun-78 & Native grassland on the Woodworth Study Area 3-East of Woodworth. \#148 \\
\hline Carex atherodes & CAAT2 & MM & 18-Jun-80 & Located on West shore of Fish Lake at Woodworth Station. \\
\hline Carex brevior & CABR10 & MM & 28-Jun-79 & $\begin{array}{l}\text { Growing in moist grassy low area with Poa pratensis. Quarter } 14 \text { in pasture. } \\
\text { UTM: } 80,330 \mathrm{mN} \text {, zone } 14 \text {. }\end{array}$ \\
\hline Carex brevior & CABR10 & MM & 21-Jul-80 & Located in Quarter 11 in Eckman Gardena Soil. UTM: 82, 700mE; 19,650mN. \\
\hline Carex eleocharis & CADU6 & MM & 28-Jun-79 & $\begin{array}{l}\text { Growing in native short grass prairie. Quarter } 12.81,500 \mathrm{~m} \mathrm{E,} \mathrm{20,} \mathrm{000m} \mathrm{N} \\
\text { UTM. Zone } 14 .\end{array}$ \\
\hline Carex eleocharis & CADU6 & MM & 8-Jun-81 & Located in Quarter 9 on dry prairie in mixed grasses. \\
\hline
\end{tabular}




\begin{tabular}{|c|c|c|c|c|}
\hline Scientific name & $\begin{array}{c}\text { USDA } \\
\text { acronym }\end{array}$ & Collector & Date & Location and original description \\
\hline Carex filifolia & CAFI & MM & 27-Jun-79 & $\begin{array}{l}\text { Growing on short grass hill tops with Bouteloua gracilis. Quarter 22. 81, } \\
600 \mathrm{mE}, 18,400 \mathrm{mN} \text { utm. Zone } 14 .\end{array}$ \\
\hline Carex interior & CAIN11 & MM & 17-Jun-80 & Located on West shore of Fish Lake in Quarter 12. \\
\hline Carex interior & CAIN11 & MM & 18-Jun-80 & Located on West shore of Fish Lake at Woodworth Station. \\
\hline Carex interior & CAIN11 & MM & 30-Jun-81 & $\begin{array}{l}\text { Located } 3 \text { miles East of Woodworth on WSA in Quarter 9-A, T142N, R67W, } \\
\text { Sec. 6. In moist meadow with other sedges. }\end{array}$ \\
\hline Carex interior & CAIN11 & MM & 30-Jun-81 & $\begin{array}{l}\text { Located } 3 \text { miles East of Woodworth on WSA in Quarter 9-A, T142N, R67W, } \\
\text { Sec. 6. In moist meadow with other sedges. }\end{array}$ \\
\hline Carex lanuginosa & CAPE42 & MM & 17-Jun-80 & $\begin{array}{l}\text { Located in Quarter } 12 \text { on west shore of Fish Lake with Erigeron philadelphicus } \\
\text { and Carex interior. }\end{array}$ \\
\hline Carex obtusata & САOB4 & MM & 6-Jun-79 & $\begin{array}{l}\text { Dry sites in mixed grass prairie. Quarter 22. UTM: 81, 350m E, 18, 700m N, } \\
\text { zone } 14 .\end{array}$ \\
\hline Carex obtusata & CAOB4 & MM & 28-Jun-79 & Mixed grass prairie. Quarter 12. UTM: 81, 500m E, 20, 000m N, zone 14. \\
\hline Carex obtusata & CAOB4 & MM & 28-Jun-79 & Mixed grass prairie. Quarter 12. UTM: 81, 500m E, 20, 000m N, zone 14. \\
\hline Carex obtusata & CAOB4 & MM & 28-Jun-79 & Mixed grass prairie. Quarter 12. UTM: 81, 500m E, 20, 000m N, zone 14. \\
\hline Carex obtusata & CAOB4 & MM & 8-Jun-81 & Located in Quarter 17 in Sioux Soil on the dry prairie. \\
\hline Carex pensylvanica & CAPE6 & MM & 6-Jun-79 & $\begin{array}{l}\text { Located in Quarter } 22 \text { with Artemisia ludoviciana and Allium and } \\
\text { Symphoricarpos. }\end{array}$ \\
\hline Carex pensylvanica & CAPE6 & MM & 27-Jun-79 & $\begin{array}{l}\text { Mixed grass prairie on slopes. Quarter 22. UTM: } 81,600 \mathrm{~m} \mathrm{E}, 18,400 \mathrm{~m} \mathrm{~N} \text {, zone } \\
14 .\end{array}$ \\
\hline Carex pensylvanica & CAPE6 & MM & 28-Jun-79 & $\begin{array}{l}\text { Growing on dry mixed grass prairie slopes. Quarter } 23 \text { UTM: 80, 900m E, 18, } \\
500 \mathrm{~m} \text { N, zone } 14 .\end{array}$ \\
\hline Carex pensylvanica & CAPE6 & MM & 28-Jun-79 & $\begin{array}{l}\text { Growing on dry, mixed grass prairie on slopes. Quarter 23. UTM: 80, 900m E, } \\
18,500 \mathrm{~m} \text { N, Zone } 14 .\end{array}$ \\
\hline Carex praegracilis & CAPR5 & MM & 24-Aug-79 & Drier high areas in mixed grass prairie. Growing in transect. Quarter 12. \\
\hline Carex praegracilis & CAPR5 & MM & 9-Jun-80 & Tall grass prairie in Quarter 9-A. \\
\hline Carex praegracilis & CAPR5 & MM & 7-Jul-80 & Located in Quarter 9-A in wet meadow. \\
\hline Carex preagracilis & CAPR5 & MM & 10-Jun-80 & Located in Quarter 4 near wetland. \\
\hline Carex rostrata & CARO6 & MM & 26-Jul-79 & $\begin{array}{l}\text { Growing in wet boggy marsh with other Carex, Epilobium and Sium suave. } \\
\text { Quarter 9-A. UTM: 83, 800m E, 21, 200m N, Zone } 14 .\end{array}$ \\
\hline Carex rostrata & CARO6 & MM & 26-Jul-79 & $\begin{array}{l}\text { Growing in wet boggy marsh with other Carex, Epilobium and Sium suave. } \\
\text { Quarter 9-A. UTM: 83, 800m E, 21, 200m N, Zone } 14 .\end{array}$ \\
\hline Cicuta maculata & CIMA2 & MM & 16-Jul-79 & $\begin{array}{l}\text { Growing on moist ground around wetlands. Flowers white. Plants up to } 1.5 \mathrm{~m} \\
\text { tall. Quarter 7. UTM: } 81,950 \mathrm{~m} \text { E, 20,700m N, zone } 14 \text {. }\end{array}$ \\
\hline Cypridpedium calceolus & CYPAP3 & LK, WB & 26-Jun-78 & Native grassland on the Woodworth Study Area 3-East of Woodworth. \#174 \\
\hline Cypridpedium calceolus & CYPAP3 & MM & 2-Jun-80 & $\begin{array}{l}\text { Located in Qtr } 22 \text { growing in colony of plants. In Hamerly soil. UTM: 81, 750m } \\
\text { E, } 18,250 \mathrm{~m} \text { N. }\end{array}$ \\
\hline
\end{tabular}




\begin{tabular}{|c|c|c|c|c|}
\hline Scientific name & $\begin{array}{c}\text { USDA } \\
\text { acronym }\end{array}$ & Collector & Date & Location and original description \\
\hline Eleocharis compressa & ELCO2 & MM & 21-May-80 & Located in Quarter 10 in moist area in small valley. \\
\hline Eleocharis macrostachya & ELMA5 & MM & 20-Aug-79 & Growing near wetland 3, quarter 9. UTM: 82, 900m E, 21, 300m N, zone 14. \\
\hline Equisetum arvense & EQAR & MM & 26-Jul-79 & Wet marsh near airstrip. Quarter 9-A. UTM: 83, 700m E, 21, 200m N, zone 14. \\
\hline Equisetum arvense & EQAR & MM & 21-May-80 & $\begin{array}{l}\text { Located in Quarter 9-A. Sandy area around wetland near gravel pit. Sterile } \\
\text { shoots. }\end{array}$ \\
\hline Equisetum arvense & EQAR & MM & 27-May-80 & $\begin{array}{l}\text { Located in Quarter } 9 \text { around wetland in sandy soil. UTM: 83, 150m E, 20, 600m } \\
\text { N. }\end{array}$ \\
\hline Equisetum hyemale & EQHY & MM, MC & 29-Jul-80 & Located in Quarter 9-A. Fen Area. \\
\hline Equisetum hyemale & EQHY & MM, MC & 30-Jul-80 & Located in Quarter 9-A. Fen Area. \\
\hline Equisetum laevigatum & EQLA & MM & 28-Jun-79 & $\begin{array}{l}\text { Moist low area with Poa pratensis. Quarter 22. UTM: 81, 530m E, 18, 800m N, } \\
\text { zone } 14 .\end{array}$ \\
\hline Equisetum laevigatum & EQLA & MM & 9-Jun-80 & In moist depression in Quarter 12. \\
\hline Equisetum laevigatum & EQLA & MM & 30-Jun-81 & $\begin{array}{l}\text { Located } 3 \text { miles East of Woodworth on WSA in Quarter 9-A, T142N, R67W, } \\
\text { Sec. 6. In a low prairie site in heavy soils. }\end{array}$ \\
\hline Habenaria hyperborea & PLAQ2 & MC, MM & 29-Jul-80 & Located in Quarter 9-A. Fen area. \\
\hline Hypoxis hirsuta & HYHI2 & MM & 28-Jun-79 & $\begin{array}{l}\text { Low grassland around wetland 33. Quarter 23. UTM: 80, 800m E, 18, 450m N, } \\
\text { zone } 14 .\end{array}$ \\
\hline Hypoxis hirsuta & HYHI2 & MC & 22-May-80 & In Quarter 7 along wet zone of pond 7-1. Flowers yellow. \\
\hline Hypoxis hirsuta & HYHI2 & MM & 27-May-80 & $\begin{array}{l}\text { Located in Quarter 22. In wet meadow around wetland. UTM: 81, 350m E, 18, } \\
100 \mathrm{~m} \mathrm{N.}\end{array}$ \\
\hline Juncus balticus & JUARL & MM & 26-Jul-79 & $\begin{array}{l}\text { Growing in moist low area near wetland 2. Qtr 16. UTM: 81, 000m E, 19, 500m } \\
\mathrm{N} \text {, zone } 14 \text {. }\end{array}$ \\
\hline Juncus bufonius & JUBU & MM & 20-Jul-79 & $\begin{array}{l}\text { Growing in moist low area in fire break. Quarter 22. UTM: 81, 500m E, 18, } \\
050 \mathrm{~m} \mathrm{~N} \text {, zone } 14 .\end{array}$ \\
\hline Juncus bufonius & JUBU & MM & 20-Jul-79 & $\begin{array}{l}\text { Growing in moist lowland area in fire break. Quarter 22. UTM: 81, 500m E, } \\
\text { zone } 14 .\end{array}$ \\
\hline Juncus dudleyi & JUDU2 & MM & 8-Jun-80 & Located on West Shore of Fish Lake. Woodworth Study Area. \\
\hline Juncus interior & JUIN2 & MM & 20-Jul-79 & $\begin{array}{l}\text { Growing in moist lowland area in fire break. Qtr 22. UTM: 81, 450m E, 18, } \\
\text { 050m N, zone } 14 .\end{array}$ \\
\hline Juncus interior & JUIN2 & MM & 20-Jul-79 & $\begin{array}{l}\text { Growing in moist lowland area in fire break. Qtr 22. UTM: 81, 450m E, 18, } \\
050 \mathrm{~m} \mathrm{~N} \text {, zone } 14 \text {. }\end{array}$ \\
\hline Juncus interior & JUIN2 & MM, MC & 16-Jun-80 & Located in Quarter 21 near dugout. \\
\hline Juncus interior & JUIN2 & MM & 17-Jun-80 & Located in Quarter 12 on west shore of Fish Lake. \\
\hline Juncus longistylis & JULO & $\mathrm{AB}$ & 8-Aug-79 & $\begin{array}{l}\text { Growing in wet meadow trampled by cattle. Clay soil. Quarter 20. UTM: 82, } \\
970 \mathrm{~m} \mathrm{E,} \mathrm{18,} \mathrm{810m} \mathrm{N,} \mathrm{zone} 14 \text {. }\end{array}$ \\
\hline Juncus longistylis & JULO & $\mathrm{AB}$ & 8-Aug-79 & $\begin{array}{l}\text { Growing in wet meadow trampled by cattle. Clay soil. Quarter 20. UTM: 82, } \\
970 \mathrm{~m} \mathrm{E}, 18,810 \mathrm{~m} \mathrm{~N} \text {, zone } 14 \text {. }\end{array}$ \\
\hline
\end{tabular}




\begin{tabular}{|c|c|c|c|c|}
\hline Scientific name & $\begin{array}{c}\text { USDA } \\
\text { acronym }\end{array}$ & Collector & Date & Location and original description \\
\hline Juncus nodosus & JUNO2 & $\mathrm{AB}$ & 8-Aug-79 & $\begin{array}{l}\text { Growing in wet meadow trampled by cattle. Clay soil. Quarter 20. UTM: 82, } \\
970 \mathrm{~m} \mathrm{E,} 18,810 \mathrm{~m} \text { N, zone } 14 \text {. }\end{array}$ \\
\hline Lemna trisulca & LETR & MM & 18-Jul-79 & $\begin{array}{l}\text { Growing in } 2 \text { to } 3 \text { feet of water in wetland \#35, qtr 7. UTM: } 81,900 \mathrm{~m} \mathrm{E,} 20 \text {, } \\
450 \mathrm{~m} \mathrm{~N} \text {, zone } 14 \text {. }\end{array}$ \\
\hline Lilium philadephicum & LIPH & MM & 10-Jul-79 & $\begin{array}{l}\text { Growing in low prairie near wetland. Flowers deep red-orange. Quarter } 14 . \\
\text { UTM: } 80,100 \mathrm{~m} \mathrm{E,} 19,650 \mathrm{~m} \text { N, zone } 14 .\end{array}$ \\
\hline Lilium philadephicum & LIPH & MM & 10-Jul-79 & $\begin{array}{l}\text { Growing in low prairie near wetland. Flowers deep red-orange. Quarter } 14 . \\
\text { UTM: } 80,100 \mathrm{mE}, 19,650 \mathrm{mN} \text {, zone } 14 \text {. }\end{array}$ \\
\hline Lomatium foeniculaceum & LOFO & $\mathrm{AB}$ & 14-May-79 & Located in Quarter 4, Sec 2, NE Corner. Flowers yellow, 7-8 cm high. \\
\hline Lomatium foeniculaceum & LOFO & MM & 23-May-79 & $\begin{array}{l}\text { Growing in mixed grass native prairie. Flowers yellow. With Anemone patens, } \\
\text { Bouteloua, and Artemisia. Quarter 4. UTM: } 80,300 \mathrm{mE}, 21,900 \mathrm{mN} \text {, zone } 14 \text {. }\end{array}$ \\
\hline Lomatium orientale & LOOR & MC & 23-Apr-80 & $\begin{array}{l}\text { Located in Quarter 10. Grazed pasture in association with Blue grama. Flowers } \\
\text { yellow. Native prairie habitat. }\end{array}$ \\
\hline Lomatium orientale & LOOR & MC & 23-Apr-80 & $\begin{array}{l}\text { Located in Quarter 10. Grazed pasture in association with Blue grama. Flowers } \\
\text { white. }\end{array}$ \\
\hline Pastinaca sativa & PASA2 & $\mathrm{AB}$ & 28-Jun-79 & $\begin{array}{l}\text { Growing on sandy lake shore south of Fish Lake. Flowers yellow. Plant } 1 \mathrm{~m} \text { tall. } \\
\text { With Scirpus and Potentilla anserina. Quarter 18. UTM: 82,720mE, } 19,410 \mathrm{mN} \text {, } \\
\text { zone } 14\end{array}$ \\
\hline Polygonatum biflorum & POBI2 & MC & 18-Jun-80 & Located in Quarter 11 along steep shore of Big Lake in brushy area. \\
\hline Polygonatum biflorum & POBI2 & MC & 18-Jun-80 & Located in Quarter 11 along steep shore of Big Lake in choke cherry thicket. \\
\hline Potamogeton gramineus & POGR8 & MM & 30-Jul-79 & $\begin{array}{l}\text { Emersed in 0.5-1.0m water in semi-permanent wetland. With } P \text {. pusillus and } P \text {. } \\
\text { gramineus. Quarter 9. UTM: 82,850mE, 21,450, zone } 14 \text {. }\end{array}$ \\
\hline Potamogeton pectinatus & STPE15 & MM & 26-Jul-79 & $\begin{array}{l}\text { Growing in 12-18 inches of water with Lemna and Drepanocladus. Quarter 16, } \\
\text { wetland 2. UTM: } 80,950 \mathrm{mE}, 19,500 \mathrm{mN} \text {, zone14. }\end{array}$ \\
\hline Potamogeton pusillus & POPUP5 & MM & 30-Jul-79 & $\begin{array}{l}\text { Emersed in 0.5-1.0m water with } P \text {. gramineus and } P \text {. richardsonii. Quarter } 9 . \\
\text { UTM: } 82,850 \mathrm{mE}, 21,450 \mathrm{mN} \text {, zone } 14 \text {. }\end{array}$ \\
\hline
\end{tabular}




\begin{tabular}{|c|c|c|c|c|}
\hline Scientific name & $\begin{array}{c}\text { USDA } \\
\text { acronym }\end{array}$ & Collector & Date & Location and original description \\
\hline Potamogeton richardsonii & PORI2 & $\mathrm{MM}$ & 17-Jun-80 & Located in Quarter 12 in shallow water in west side of Fish Lake. \\
\hline Potamogeton richardsonii & PORI2 & MM & 17-Jun-80 & Located in Quarter 12 in shallow water on west shore of Fish Lake. \\
\hline Puccinellia nuttalliana & PUNU2 & $\mathrm{MM}$ & 12-Jul-79 & $\begin{array}{l}\text { Growing in low prairie in pasture. Qtr. 20. UTM: } 82,900 \mathrm{mE}, 18,800 \mathrm{mN} \text {, zone } \\
14 .\end{array}$ \\
\hline Puccinellia nuttalliana & PUNU2 & MM & 18-Jun-80 & Located in Quarter 12 West shore of Fish Lake. \\
\hline Puccinellia nuttiana & PUNU2 & MM & 12-Jul-79 & $\begin{array}{l}\text { Growing in low prairie pasture. Quarter 20. UTM: } 82,900 \mathrm{mE}, 18,800 \mathrm{mN} \text {, zone } \\
14 .\end{array}$ \\
\hline Rhus radicanis & TORY & MC & 29-Aug-80 & Large patch growing near Crataegus Clumps. \\
\hline Sagittaria cuneata & SACU & MM & 2-Jul-80 & Located in Quarter 12 in wetland near station in draw down damp basin. \\
\hline Sagittaria cuneata & SACU & MM & 2-Jul-80 & Located in Quarter 12 in wetland near station. In a damp basin. \\
\hline Schedonnardus paniculatus & SCPA & MC & $6 / 25 / 1980$ & Located in Quarter 10 on dry prairie in association with Bouteloua. \\
\hline Scirpus actutus & SCACA & MM, CS & 28-Jul-81 & Located in Quarter 4 around wetlands. \\
\hline Scirpus americanus & SCAM2 & MM & 6-Aug-79 & $\begin{array}{l}\text { Growing in } 2 \text { inches of water near edge of large wetland. Quarter 9-A. UTM: } \\
84,150 \mathrm{mE}, 20,450 \mathrm{mN} \text {, zone } 14 \text {. }\end{array}$ \\
\hline Scirpus atrovirens & SCAT2 & MM & 6-Aug-79 & Growing in Carex wet marsh. Quarter 9. UTM: 83, 800mE, 21, 200mN, aone14. \\
\hline Scirpus fluviatilis & SCFL11 & MM & 30-May-79 & $\begin{array}{l}\text { Located in wet marsh of sedge bordered with willows. Quarter 9. UTM: 83, } \\
750 \mathrm{mE}, 21,200 \mathrm{mN} \text {, zone } 14 \text {. }\end{array}$ \\
\hline Scirpus fluviatilis & SCFL11 & MM & 30-May-79 & $\begin{array}{l}\text { Wet Carex marsh boarded with Willows. Quarter 9. UTM: 83, 750mE, 21, } \\
\text { 200mN, zone } 14 \text {. }\end{array}$ \\
\hline Scirpus validus & SCVA & $\mathrm{AB}$ & 27-Jun-79 & $\begin{array}{l}\text { Emerging from } 1 \mathrm{ft} \text {. water in channel leading into large lake. With Senecio } \\
\text { congestus. To } 1 \mathrm{~m} \text { tall. Quarter 12. UTM: 81, 750mE 20, 200mN, zone } 14 .\end{array}$ \\
\hline Scirpus validus & SCVA & $\mathrm{AB}$ & 20-Jul-79 & $\begin{array}{l}\text { Border of large lake to } 2 \mathrm{~m} \text { tall. Quarter } 12 \text {. UTM:81, 700mE, 20, } 100 \mathrm{mN} \text {, zone } \\
14 .\end{array}$ \\
\hline Scirpus validus & SCVA & MM & 28-Jul-81 & Located in Quarter 12 around Clark Lake. \\
\hline Scirpus validus & SCVA & MM, CS & 28-Jul-81 & Located in Quarter 12 around Clark Lake. \\
\hline Scirpus validus & SCVA & $\mathrm{AB}$ & 27-Jun-79 & $\begin{array}{l}\text { Located in Channel leading into large lake emerging from lift of water. Quarter } \\
\text { 12. UTM: } 81,750 \mathrm{mE}, 20,200 \mathrm{mN} \text {, zone } 14 .\end{array}$ \\
\hline Scolochloa festucacea & SCFE & MM & 20-Jul-79 & $\begin{array}{l}\text { Growing in } 2 \text { feet of water in wetland 23. Quarter 22. UTM: 81,450mE, } \\
18,050 \mathrm{mN} \text {, zone } 14 \text {. }\end{array}$ \\
\hline Scripus americanus & SCAM2 & MM & 6-Aug-79 & $\begin{array}{l}\text { Growing in } 2 \text { inches of water near edge of large wetland. Quarter 9-A. UTM: } \\
84,150 \mathrm{mE}, 20,450 \mathrm{mN} \text {, zone } 14 .\end{array}$ \\
\hline Setaria glauca & SEPUP2 & MM & 22-Aug-79 & $\begin{array}{l}\text { Growing in disturbed prairie which had been burning during spring. Quarter } 18 \text {. } \\
\text { UTM: 82,100mE, 19,200mN, zone } 14 \text {. }\end{array}$ \\
\hline Setaria viridis & SEVI4 & MM & 22-Aug-79 & $\begin{array}{l}\text { Growing in disturbed prairie which had been burning during spring. Quarter } 18 . \\
\text { UTM: } 82,000 \mathrm{mE}, 19,400 \mathrm{mN} \text {, zone } 14 \text {. }\end{array}$ \\
\hline Sisyrinchium angustifolium & SIAN3 & MM & 23-Jun-80 & Located in Quarter 8 on dry prairie hilltops. \\
\hline Sisyrinchium montanum & SIMO2 & $\mathrm{KH}, \mathrm{EL}$ & 26-Jun-78 & Native grassland on the Woodworth Study Area 3-East of Woodworth. \#176 \\
\hline
\end{tabular}




\begin{tabular}{|c|c|c|c|c|}
\hline Scientific name & $\begin{array}{c}\text { USDA } \\
\text { acronym }\end{array}$ & Collector & Date & Location and original description \\
\hline Smilacina stellata & MAST4 & $\mathrm{MM}$ & 6-Jun-79 & $\begin{array}{l}\text { Growing in understory of shrubs along south side of Fish Lake, flowers white. } \\
\text { Quarter 18. UTM: 82, 800mE, } 19,400 \mathrm{mN} \text {, zone } 14 .\end{array}$ \\
\hline Smilax herbacea & SMHE & $\mathrm{MM}$ & 18-Jul-79 & $\begin{array}{l}\text { Growing in shrub area on S. side of Fish Lake. Qtr 18. UTM: 82, 500mE, 19, } \\
400 \mathrm{mN} \text {, zone } 14 .\end{array}$ \\
\hline Smilax herbacea & SMHE & KH, LHM & 17-Jul-81 & $\begin{array}{l}\text { Located } 2 \text { miles East of Woodworth. T142N, R68W, Sec. 10. Located on the } \\
\text { edge of a Juneberry clump. }\end{array}$ \\
\hline Sorghastrum avenaceum & SONU2 & $\mathrm{AB}$ & 20-Aug-79 & $\begin{array}{l}\text { Damp grassy meadow with Andropogon gerardi. Plants to } 1 \mathrm{~m} \text { tall. Quarter } 9 . \\
\text { UTM: } 83,500 \mathrm{mE}, 20,700 \mathrm{mN} \text {, zone } 14 \text {. }\end{array}$ \\
\hline Sparganium eurycarpum & SPEU & MM & 8-Jul-81 & Located in Quarter 12 in moist ground around dry wetland. 2 stigmas. \\
\hline Spartina gracilis & SPGR & $\mathrm{KH}, \mathrm{EL}$ & 22-Jun-78 & Native grassland on the Woodworth Study Area 3-East of Woodworth. \#143 \\
\hline Spartina pectinata & SPPE & MM & 6-Aug-79 & Growing in wet Carex marsh. Quarter 9. UTM: 83,800mE, 21,150mN, zone 14. \\
\hline Sporobolus cryptandrus & SPCR & MC & 29-Aug-80 & $\begin{array}{l}\text { Along a R.R. track in Quarter 9-A in heavily sprayed area only plant growing in } \\
\text { this spray zone. }\end{array}$ \\
\hline Sporobolus heterolepis & SPHE & RK, MM & 27-Aug-79 & Transect 8, Quarter 9. \\
\hline Stipa comata & HECOC8 & MM & 9-Jun-80 & Found on airstrip in Quarter 9-A \\
\hline Stipa Comata & HECOC8 & MM & 10-Jul-80 & Located in Quarter 12 in Fordville Soil. \\
\hline Stipa spartea & HESP11 & MC & 23-Jun-80 & Located in Qtr. 22. \\
\hline Stipa spartea & HESP11 & $\mathrm{MM}$ & 10-Jul-80 & Located in Quarter 12 in Fordville Soil. \\
\hline Stipa viridula & NAVI4 & $\mathrm{MM}$ & 10-Jul-80 & Located in Quarter 12 in Fordville Soil. \\
\hline Stipa viridula & NAVI4 & MM & 18-Jul-80 & Located in Quarter 9. \\
\hline
\end{tabular}




\begin{tabular}{|c|c|c|c|c|}
\hline Scientific name & $\begin{array}{c}\text { USDA } \\
\text { acronym }\end{array}$ & Collector & Date & Location and original description \\
\hline Typha augustifolia & TYAN & MM & 10-Jul-79 & $\begin{array}{l}\text { Growing in } 2 \mathrm{dm} \text { water in quarter 7, Wetland 10. UTM: } 81,300 \mathrm{mE}, 21,150 \mathrm{mN} \text {, } \\
\text { zone } 14 \text {. }\end{array}$ \\
\hline Zannichellia palustris & ZAPA & MM & 18-Jul-79 & $\begin{array}{l}\text { Emersed in two feet of water in seasonal wetland. Quarter } 8 \text {. UTM: } 81,950 \mathrm{mE} \text {, } \\
20,450 \mathrm{mN} \text {, zone } 14 \text {. }\end{array}$ \\
\hline Zigadenus elegans & ZIEL2 & $\mathrm{AB}$ & 2-Jul-79 & $\begin{array}{l}\text { Located in Quarter 9; section 6, SW corner. UTM: 83, 080E, 20, 580N. Soil- } \\
\text { loose, moist, silty loam. Flowers greenish white. Plants 60-100cm tall. }\end{array}$ \\
\hline Zigadenus elegans & ZIEL2 & $\mathrm{AB}$ & 2-Jul-79 & $\begin{array}{l}\text { Located in Quarter 9; section 6, SW corner. UTM: 83, 080E, 20, 580N. Soil- } \\
\text { loose, moist, silty loam. Flowers greenish white. Plants 60-100cm tall. }\end{array}$ \\
\hline Zigadenus elegans & ZIEL2 & $\mathrm{AB}$ & 2-Jul-79 & $\begin{array}{l}\text { Moist depression along marshy pothole. Loose, moist silty loam. Flowers } \\
\text { greenish white. Plants 6-10dm tall. With Commandra, Asclepias. Quarter } 9 . \\
\text { UTM: } 83,080 \mathrm{mE}, 20,580 \mathrm{mN} \text {, zone } 14 .\end{array}$ \\
\hline Zigadenus elegans & ZIEL2 & $\mathrm{AB}$ & 2-Jul-79 & $\begin{array}{l}\text { Moist depression along marshy pothole. Loose, moist silty loam. Flowers } \\
\text { greenish white. Plants 6-10dm tall. With Commandra, Asclepias. Quarter } 9 . \\
\text { UTM: } 83,080 \mathrm{mE}, 20,580 \mathrm{mN} \text {, zone } 14 .\end{array}$ \\
\hline Zizia aptera & ZIAP & KH, EL & 8-Jun-78 & Native grassland on the Woodworth Study Area 3-East of Woodworth. \#121 \\
\hline Zizia aptera & ZIAP & $\mathrm{AB}$ & 6-Jun-79 & $\begin{array}{l}\text { Growing in boggy pothole in tall dead grass. Petals yellow, plant } 2.5 \mathrm{dm} \text { tall. } \\
\text { With Viola nephrophylla and Stipa. Quarter 9. UTM: 83,900, 21,200mN, zone } \\
14 .\end{array}$ \\
\hline
\end{tabular}




\section{Appendix 12. Aerial imagery available for the Woodworth Study Area (WSA) and surrounding area for 1957-97}

[Date is when the images or recording was made; media is the format. Originals prints, where available, are kept in the archive room of Northern Prairie Wildlife Research Center, and select collections are currently available digitally. Notes provide useful information describing the imagery. A mark under the last column indicates that the images are immediately viewable, meaning they are in photographic form, the WSA area is complete, and the images have an associated month and year.]

\begin{tabular}{|c|c|c|c|c|}
\hline Date & Media & Notes (complete, label names) & Area & $\mathrm{X}$ \\
\hline 1949-1951 & $\begin{array}{l}\text { Black and } \\
\text { white print }\end{array}$ & $\begin{array}{l}\text { Eddy tract folder; study units } 8,12 \text {, } \\
13,15,16\end{array}$ & Eddy tract & \\
\hline 1957-July & $\begin{array}{l}\text { Digital color } \\
\text { image }\end{array}$ & & $\begin{array}{l}\text { Full WSA and } \\
\text { surrounding area }\end{array}$ & $x$ \\
\hline 1963-May 3 & $\begin{array}{l}\text { Black and } \\
\text { white prints }\end{array}$ & $\begin{array}{l}\text { Altitude of 3,000 feet; A1->A3, B1- } \\
\text { >B6, C1->C8, D1->D6, E1->E3; } \\
\text { flying from south to north beginning } \\
\text { on the west, into a northwest wind; } \\
\text { taken same day at } 1 \text { b. }\end{array}$ & Full WSA & $x$ \\
\hline 1963-May 3 & $\begin{array}{l}\text { Black and } \\
\text { white prints }\end{array}$ & $\begin{array}{l}\text { Altitude of 9,000 feet; I1 -> I6, II- } \\
\text { >II6, III1->III6; one photo is missing } \\
\text { from this collection (I-2) }\end{array}$ & Full WSA & $x$ \\
\hline 1963-August 22 & $\begin{array}{l}\text { Black and } \\
\text { white prints }\end{array}$ & Labeled 1-35 & Full WSA & $x$ \\
\hline 1964- May 24 & $\begin{array}{l}\text { Digital Black } \\
\text { and white } \\
\text { images }\end{array}$ & & $\begin{array}{l}\text { Full WSA and } \\
\text { surrounding area }\end{array}$ & $x$ \\
\hline 1966-May & $\begin{array}{l}\text { Black and } \\
\text { white prints }\end{array}$ & $\begin{array}{l}\text { Labeled 1-8 (WSA), 28-31, and 36- } \\
39\end{array}$ & Full WSA & $x$ \\
\hline 1968- May 31 & $\begin{array}{l}\text { Black and } \\
\text { white prints, } \\
\text { positive } \\
\text { transparencies }\end{array}$ & $\begin{array}{l}\text { "High" and "low" altitude, } 2 \text { inch } \times 2 \\
\text { inch prints }\end{array}$ & & $x$ \\
\hline 1969-May 1 & $\begin{array}{l}\text { Black and } \\
\text { white prints }\end{array}$ & 168-170, 177, 179, 186 & $\begin{array}{l}\text { Full WSA and } \\
49 \text { square-mile } \\
\text { area around } \\
\text { WSA }\end{array}$ & $x$ \\
\hline 1969-May 1 & $\begin{array}{l}\text { Black and } \\
\text { white prints }\end{array}$ & Labeled 269-304 & $\begin{array}{l}\text { Full WSA and } 9 \\
\text { square-mile area } \\
\text { around WSA }\end{array}$ & $x$ \\
\hline
\end{tabular}




\begin{tabular}{|c|c|c|c|c|}
\hline Date & Media & Notes (complete, label names) & Area & $\mathrm{X}$ \\
\hline 1970-July 31 & $\begin{array}{l}\text { Color- } \\
\text { infrared prints }\end{array}$ & $70 \mathrm{~mm}$ & & \\
\hline 1972-July 28 & $\begin{array}{l}\text { Black and } \\
\text { white prints } \\
\text { and positive } \\
\text { transparencies }\end{array}$ & Altitude of 4,500 feet & & $x$ \\
\hline 1973-May 12 & $\begin{array}{l}\text { Various } \\
\text { media }\end{array}$ & $\begin{array}{l}\text { Altitude of } 4,500 \text { feet; Prints (9 inch } \\
\times 9 \text { inch), color } 70 \mathrm{~mm}\end{array}$ & $\begin{array}{l}\text { WSA in } 6 \\
\text { transects }\end{array}$ & $x$ \\
\hline 1973-August 12 & $\begin{array}{l}\text { Various } \\
\text { media }\end{array}$ & $\begin{array}{l}\text { Color infrared ( } 9 \text { inch } \times 9 \text { inch), } \\
70 \mathrm{~mm} \text { positive transparency; } 2 \text { inch } \\
\times 2 \text { inch black and white prints }\end{array}$ & & $\mathrm{x}$ \\
\hline 1980-August 21 & Negatives & Altitude of 6,000 feet; Labeled 1-19 & Full WSA & \\
\hline 1978-79-May & $\begin{array}{l}\text { Negatives, } \\
\text { prints }\end{array}$ & $\begin{array}{l}\text { Labeled by study unit; unclear if the } \\
\text { negatives (1978) or the prints (1979) } \\
\text { are labeled correctly; photographs } \\
\text { are slightly out of focus. }\end{array}$ & $\begin{array}{l}\text { Full WSA, with } \\
\text { surrounding area }\end{array}$ & \\
\hline 1979-May 16 & $\begin{array}{l}\text { Color digital } \\
\text { images }\end{array}$ & National Wetland Inventory & $\begin{array}{l}\text { WSA and } \\
\text { surrounding } \\
\text { areas }\end{array}$ & $\mathrm{x}$ \\
\hline 1983-1991 & $\begin{array}{l}\text { Color digital } \\
\text { images }\end{array}$ & $\begin{array}{l}\text { NRCS slides for all WSA study } \\
\text { units; Month, date unclear }\end{array}$ & & \\
\hline 1996 or 1997 & $\begin{array}{l}\text { Black and } \\
\text { white digital } \\
\text { images }\end{array}$ & $\begin{array}{l}\text { Digital orthophoto quadrangles in } \\
\text {.bil raster forma; month and date } \\
\text { unclear. }\end{array}$ & WSA proper & \\
\hline 1988-April 30 & Aerial video & Altitude of 12,500 feet; 10.5 mm lens & & \\
\hline 1989-Nov 28 & Aerial video & & & \\
\hline Unknown & Prints & $\begin{array}{l}\text { Labeled } 1-1 \text { through } 1-43 \text {; noted on } \\
\text { back "Must be after 1965." }\end{array}$ & & \\
\hline Unknown & Prints & $\begin{array}{l}\text { WSA photos are labeled } 207-210 \text {, } \\
214,239 ; \text { surrounding area is } 211- \\
213,215 \text {; HQ has the south building } \\
\text { by this time. }\end{array}$ & WSA & \\
\hline Unknown & Photos & Labeled lines 1-6 and 2-11 & $\begin{array}{l}\text { Full WSA; } \\
\text { Missing } 3 \text { of } 60 \\
\text { for surrounding } \\
\text { areas }\end{array}$ & \\
\hline
\end{tabular}




\title{
Appendix 13. Example of metadata used to document and preserve Woodworth Study Area (WSA) datasets
}

\author{
Dataset: \\ Coordinate endpoint of Meyer vegetation transects at woodworth study Area, 1980 \\ Description: \\ This dataset includes the approximate latitude and longitude of endpoints of the Meyer vegetation transects. \\ Tent stakes were apparently placed as markers (K. F. Higgins, pers. Commun., 2014), but these points have not been ground
truthed. The transects were traced into Arcmap from the 1979 protocol report (1979-proposal-unknownauthor-Meyer-vegetation- \\ survey. pdf \\ physical markers have been found to validate their location, coordinates recorded here are approximate. coordinates are in \\ decimal degrees in coordinate system NAD83 UTM Zone 14N. It is unknown whether the coordinates reported here are the beginning \\ or end of the transects. The ID values were pieced together from maps, the most helpful being 1979-notes-Meyer-vegetation- \\ soil-survey.pdf. IDs with values of 99 ( 3 locations, a11 in study unit 9A) are approximate 1ocations of transects that were \\ marked as needing posts (1979-map-Meyer-transects-needing-posts.pdf). The points are included here for completeness, though \\ some or all may actually be the same transects as any of their neighboring transects in study unit 9A. The data collected at \\ these transects were percent cover of vegetation and environmental data, similar to long-term studies VEGETRAN, NV2TRAN, and \\ WWVEG. Data was reported in Meyer, M. (1985) Classification of native vegetation at the woodworth station, North Dakota,
Prairie Naturalist $17(3)$, p. 167-175. \\ Source: Digitized to ArcMap 10.1 from 1979-proposal-unknownauthor-Meyer-vegetation-survey.pdf, 1abeled with 1979- \\ notes-Meyer-vegetation-soil-survey.pdf \\ File: $\quad$ Meyer-transects-approx-points.txt \\ Re1ated: 1979-notes-Meyer-vegetation-soi1-survey.pdf, 1979-proposa1-unknownauthor-Meyer-vegetation-survey. pdf, 1979- \\ protocol-vegetation-study-codes.pdf, 1979-map-Meyer-transect's-needing-posts.pdf \\ Label su: $\quad$ Study unit the transect lies in, following conventional wSA assignment (1-24). \\ Label TR_M1: Identifies the transect number. Unless noted, assigned at the time of survey. \\ Labe1 TYPE: object type. The transects are represented by only an endpoint. \\ Label XCOORD: $\quad x$ coordinate of one end of the transect, decimal degrees in coordinate system NAD83 UTM Zone 14N. \\ Label YCOORD: Y coordinate of one end of the transect, decimal degrees in coordinate system NAD83 UTM Zone $14 \mathrm{~N}$.

\begin{tabular}{|c|c|c|c|c|}
\hline $\begin{array}{l}5 \mathrm{~S} \\
4 \\
4 \\
7 \\
7 \\
7 \\
7 \\
8 \\
8 \\
8 \\
8 \\
8 \\
8 \\
8 \\
9 \\
9 \\
9 \\
9 \\
12 \\
13 \\
13 \\
13 \\
13 \\
13 \\
16 \\
16 \\
16 \\
17 \\
17\end{array}$ & $\begin{array}{l}\mid \text { TR_M1 } \\
11 \\
12 \\
13 \\
14 \\
145 \\
46 \\
15 \\
22 \\
23 \\
41 \\
42 \\
99 \\
29 \\
3 \\
4 \\
32 \\
7 \\
16 \\
17 \\
24 \\
25 \\
26 \\
18 \\
19 \\
39 \\
1 \\
27\end{array}$ & $\begin{array}{l}\text { TYPE } \\
\text { point } \\
\text { point } \\
\text { point } \\
\text { point } \\
\text { point } \\
\text { point } \\
\text { point } \\
\text { point } \\
\text { point } \\
\text { point } \\
\text { point } \\
\text { point } \\
\text { point } \\
\text { point } \\
\text { point } \\
\text { point } \\
\text { point } \\
\text { point } \\
\text { point } \\
\text { point } \\
\text { point } \\
\text { point } \\
\text { point } \\
\text { point } \\
\text { point } \\
\text { point } \\
\text { noint }\end{array}$ & \begin{tabular}{|} 
XCOORD \\
-99.26067 \\
-99.26032 \\
-99.24844 \\
-99.2482 \\
-99.24679 \\
-99.24693 \\
-99.23637 \\
-99.23313 \\
-99.23334 \\
-99.22874 \\
-99.22863 \\
-99.23036 \\
-99.22385 \\
-99.22427 \\
-99.2186 \\
-99.21788 \\
-99.24214 \\
-99.25792 \\
-99.25329 \\
-99.25255 \\
-99.25736 \\
-99.25937 \\
-99.24974 \\
-99.24963 \\
-99.25184 \\
-99.24493 \\
$n n .21137$
\end{tabular} & \begin{tabular}{|}
$\mid$ YCOORD \\
47.15143 \\
47.15174 \\
47.14146 \\
47.14205 \\
47.13984 \\
47.13951 \\
47.13998 \\
47.14056 \\
47.14092 \\
47.14371 \\
47.14307 \\
47.13965 \\
47.14313 \\
47.14289 \\
47.13902 \\
47.14159 \\
47.13341 \\
47.13654 \\
47.13645 \\
47.13643 \\
47.13654 \\
47.13294 \\
47.13029 \\
47.12874 \\
47.1249 \\
47.1315 \\
47.13155
\end{tabular} \\
\hline
\end{tabular}

